NBER WORKING PAPER SERIES

\title{
BEHAVIORAL RESPONSES TO STATE INCOME TAXATION OF HIGH EARNERS: EVIDENCE FROM CALIFORNIA
}

\author{
Joshua Rauh \\ Ryan J. Shyu \\ Working Paper 26349 \\ http://www.nber.org/papers/w26349 \\ NATIONAL BUREAU OF ECONOMIC RESEARCH \\ 1050 Massachusetts Avenue \\ Cambridge, MA 02138 \\ October 2019, Revised May 2021
}

We are grateful to the California Franchise Tax Board (FTB) for providing the data used in this study, and especially to Allen Prohofsky and Chad Angaretis. We thank Daniel Feenberg for help with TAXSIM, Greg Kearney for research assistance, and Jonathan Berk, Juan Carlos Suárez Serrato, Gal Wettstein, Danny Yagan, Owen Zidar, Eric Zwick, and participants at the NBER Public Economics Program Meeting (Fall 2019) and the National Tax Association's 112th Annual Conference on Taxation for helpful comments, discussions, and feedback. Ryan Shyu's work on this paper occurred while affiliated with Stanford GSB. This work was supported in part by a grant from the Laura and John Arnold Foundation, from which we gratefully acknowledge support (references 130402FX and SPO 130402). The views expressed herein are those of the authors and do not necessarily reflect the views of the National Bureau of Economic Research.

NBER working papers are circulated for discussion and comment purposes. They have not been peer-reviewed or been subject to the review by the NBER Board of Directors that accompanies official NBER publications.

(C) 2019 by Joshua Rauh and Ryan J. Shyu. All rights reserved. Short sections of text, not to exceed two paragraphs, may be quoted without explicit permission provided that full credit, including $(\odot$ notice, is given to the source. 
Behavioral Responses to State Income Taxation of High Earners: Evidence from California Joshua Rauh and Ryan J. Shyu

NBER Working Paper No. 26349

October 2019, Revised May 2021

JEL No. H24,H31,H71,H73,J22,J61,R23

\begin{abstract}
$\underline{\text { ABSTRACT }}$
Using administrative income tax data, we analyze the response to Proposition 30, a 2012 ballot measure that increased California marginal tax rates by up to 3 percentage points for high-income households. Relative to baseline rates of departure for their income levels, an additional $0.8 \%$ of the residential tax base that landed in the top bracket left California in 2013. Using matched outof-state taxpayers as controls reveals an income elasticity with respect to the marginal net-of-tax rate of 2.5-3.2 for high-earners who stayed. These responses together eroded $45.2 \%$ of state windfall tax revenues within the first year and $60.9 \%$ within two years, with the extensive margin accounting for $9.5 \%$ of this total.
\end{abstract}

Joshua Rauh

Graduate School of Business

Stanford University

Stanford, CA 94305

and Hoover Institution

and also NBER

rauh@stanford.edu

Ryan J. Shyu

Amazon.com, Inc.

440 Terry Avenue

North Seattle, WA 98109

ryan.j.shyu@gmail.com 


\section{Introduction}

The empirical public finance literature has studied the elasticity of taxable income with respect to marginal net of tax rates as a measure of the efficiency of a tax system (Saez, Slemrod and Giertz 2012 ). In the leading approach for examining the elasticity of taxable income for the personal income tax (Gruber and Saez 2002; Giertz 2007, Kleven and Schultz 2014), the percent change in taxable income is estimated as a function of the percent change in marginal tax rates and a term designed to capture income effects, alongside a rich set of controls for base-period income. The literature's conclusion based on this methodology has generally been that the compensated elasticity of taxable income with respect to marginal tax rates is in the range of 0.1 to 0.4 , while the income effects that would lead to greater labor supply under higher taxes are essentially negligible. These relatively modest elasticities have generally translated into calculations of high optimal marginal tax rates (Saez 2001; Piketty, Saez and Stantcheva 2014), with perhaps the most widely cited calculation being a top optimal tax rate of 73 percent (Diamond and Saez 2011).

At the same time, a growing literature documents the rise in tax avoidance and evasion by wealthy individuals (Zucman 2014). Agrawal and Foremny (2019) and Kleven et al. (2014) document a tendency of high earners to relocate in response to changes in the top tax rate in Spain and Denmark. In the context of inventors, Moretti and Wilson (2017) and Akcigit, Baslandze and Stantcheva (2016) investigate the influence of taxation on mobility across state lines within the U.S., and international boundaries, respectively. On the other hand, Varner, Young and Prohofsky (2018) and Young et al. (2016) use administrative tax data in U.S. states and find relatively small migration responses to changes in top income tax rates. The quantitative implications of such behavioral responses remain an active topic of inquiry. Overall, the impact of cross-border mobility of individuals and capital on the elasticity of the taxable income for states within the U.S. or within other unions with free labor mobility is an open question.

In this paper we study the question of the elasticity of the tax base with respect to taxation using microdata from the California Franchise Tax Board (FTB) on the universe of California taxpayers around the implementation of major 2012 ballot initiative, Proposition 30. California is the largest U.S. state by GDP, comparable to the economy of the 5th or 6th largest country in the world. The Proposition 30 ballot initiative increased marginal income tax rates by 1 percentage point for singles with $\$ 250,000-\$ 300,000$ in taxable income (married couples with $\$ 500,000-\$ 600,000$ ), by 2 percentage points for singles with $\$ 300,000-\$ 500,000$ in taxable income (married couples with $\$ 600,000-\$ 1$ million), and by 3 percentage points for singles with over $\$ 500,000$ in taxable income (married couples with over $\$ 1$ million). These increases came on top of the $9.3 \%$ rate that applied to income over $\$ 48,942$ for singles and $\$ 97,884$ for married couples, and also in addition to a $1 \%$ income tax to support mental health expenditures that since 2004 had applied to incomes of over $\$ 1$ million. The reform therefore brought the top marginal tax rate in California to $13.3 \%$ for incomes of over $\$ 1$ million, the highest state-level marginal tax rate in the nation. The reform was voted in November 2012 and applied retroactively to tax year 2012 as well as for future tax years through 
2018. California Proposition 55 during the 2016 election year extended these rate increases through 2030.

We first study the extensive margin response to taxation, and document a substantial onetime outflow of high-earning taxpayers from California in response to Proposition 30. Defining a departure as a taxpayer who went from resident to non-resident filing status, ${ }^{1}$ For those earning over $\$ 5$ million, the rate of departures spiked from 1.5\% after the 2011 tax year to $2.125 \%$ after the 2012 tax year, with a similar effect among taxpayers earning $\$ 2-5$ million in 2012 . The increase in departure rate is significant but smaller for taxpayers in the new top bracket earning under $\$ 2$ million. The fact that the effect increases with income is consistent with the established theory that average tax rates matter for extensive margin individual location decisions (Moretti and Wilson 2017, Agrawal and Foremny 2019). ${ }^{2}$ These results highlight the importance of considering the extensive margin of taxpayer behavior when examining state-level tax changes. On the whole, relative to the pre-period 2000-10, the income-weighted rate of departure amongst top-bracket taxpayers was abnormally higher by $0.8 \%$ between 2012 and $2013 .^{3}$

Gauging the size of the increased incentive to relocate is complicated by the fact that federal tax policy also changed between 2012 and 2013. The U.S. Congress passed the American Taxpayer Relief Act (ATRA) of 2012 on January 1, 2013, which increased the top marginal tax rate for single filers earning $\$ 400,000$ or more (and couples earning $\$ 450,000$ or more) from $35 \%$ to $39 \%$, except for those taxpayers whose income and deductions caused their marginal rate to be determined by the alternative minimum tax (AMT). The federal tax increase reduced the incentive to move from California for taxpayers not in the AMT, since the full deductibility of state and local taxes that prevailed at the time became more valuable. We estimate that the treatment on California households' average tax rates relative to the average tax rates they would have faced in zero-incometax states such as Nevada, Texas, and Florida would have been 23-40\% higher (depending on their income level and composition) in the absence of ATRA.

We combine these results on the extensive margin behavioral response with conclusions of analysis of the intensive margin response to Proposition 30. Our focus on the California tax reform on this margin is motivated by the need for a credible counterfactual group to assess the average treatment effect of Proposition 30 on the pre-tax income of California high earners. Much of the empirical public finance literature studies population-level reforms (i.e. federal tax reforms) and thus must use taxpayers of different income levels to impute the potential outcomes of treated groups, with the aid of regression adjustments.

\footnotetext{
${ }^{1}$ Since non-residents of California must file a California return if they have any California-source income, this procedure captures essentially all tax-compliant movers. The out migration effect is primarily accounted for by taxpayers who remain non-resident filers in the 2014 tax year; we discuss this mode of out migration at length in Section 5.a.1 On average, the state loses $83.6 \%$ of the adjusted-gross income tax base of top-bracket out-movers within two years from this mode of migration, with the remaining income continuing to be taxed in 2014 on non-resident tax returns these individual submit.

${ }^{2}$ Analogous intuition on the importance of average tax rates for extensive margin decisions is found in the literature on firm location choices. See for example Devereux and Griffith 1998

${ }^{3}$ Of the 66,936 primary taxpayers whom Proposition 30 placed in the to $12.3 \%$ bracket in 2012 , this implies an income-weighted increase in departures of 535 top-bracket taxpayers.
} 
We take a different approach: in particular, we use a differences-in-differences design in which we compare upper-income California resident taxpayers to a matched sample of non-resident California filers, for which there is relatively rich data given that any substantive California-source income requires the filing of a California tax return even by non-residents. ${ }^{4}$

Our procedure in particular focuses on the intensive-margin impact of Proposition 30 on those California taxpayers whose income levels in each of the years 2009, 2010, and 2010 would have placed them in the Proposition 30 top bracket if that bracket had been in place at the time. The motivation for using this definition of high-earners is the well known issue in the empirical public finance literature that top incomes are highly mean reverting. In a recent treatment of this topic, Weber (2014) shows that using long lags of income to instrument for pre-treatment income increases estimation credibility. Requiring consistently high pre-Proposition 30 incomes is a simple way to translate this intuition into the definition of a treatment group in our setting. The counterfactual control group of non-resident filers is then defined to be those taxpayers who do not reside in California, but file California non-resident returns, and who if California residents would have filed in the top California Proposition 30 created bracket from 2009-11.

While there is no evidence of substantially different pre-trends between our treatment and control populations, they are imbalanced on covariates. We thus use propensity score matching as a pre-processing step, matching only on 2009-10 covariates. Following the logic in Imbens and Wooldridge (2009), the equality of covariate values in 2011 is a testable implication of the unconfoundedness assumption; we indeed find that this restriction is satisfied, increasing confidence in the estimation design.

Our estimates show a substantial intensive margin response to Proposition 30, which appears in 2012 and persists through the last year of our analysis in 2014. Compared to matched nonresident counterfactuals, California top-earners on average report $\$ 522,000$ less in taxable income in 2012, $\$ 357,000$ less in 2013 , and $\$ 599,000$ less in 2014; this is relative to a baseline mean income of $\$ 4.15$ million amongst our defined group of California top-earners in 2011. Compared to counterfactuals in similarly high-tax states, California top-earners on average report $\$ 352,000$ less in taxable income in $2012, \$ 373,000$ less in 2013 , and $\$ 481,000$ less in 2014 . The appearance of an intensive margin response in 2012 is consistent with the fact that Proposition 30 was retroactive to 2012, was known to have a substantial chance of passage, and in general was a salient issue in California during the bulk of 2012. ${ }^{5}$ We also estimate the average effect in logs, which leads to even larger estimates. This intensive margin response is concentrated in non-investment income, not in capital gains, dividends, and interest income.

Using the levels result from 2013 and the more conservative similar-tax state counterfactuals, the estimates imply an elasticity of taxable income with respect to the marginal net-of-tax rate of 2.5 to 3.2. This is a large estimate, especially relative to the classic public finance literature. Although it is estimated on a population of taxpayers earning over $\$ 4$ million dollars annually

\footnotetext{
${ }^{4}$ Such filers on average have a California AGI to Federal AGI ratio of between $4.8 \%$ and $7.5 \%$ over the course of the 2009-14 period

${ }^{5}$ See the discussion of the Proposition 30 institutional setting in Section 3
} 
in taxable income, we note that according to the latest FTB statistics approximately $40 \%$ of the individual income tax in California is paid by those with taxable income of over $\$ 1$ million. Using a midpoint of 2.8 as an elasticity of taxable income with respect to the marginal net of tax rate implies a revenue-maximizing state tax rate of $19 \%\left(=\frac{1}{1+1.5 * 2.8}\right)$, at least during a regime when state income taxes were deductible from federal taxable income as was the case before the Tax Cut and Jobs Act of 2017.

We do not take a stand on the broad normative implications of our estimates. For example, one possibility is that lower earnings in response to high tax rates reflects a reduction in productive labor supply amongst high earners. On the other hand, as shown by Piketty, Saez and Stantcheva (2014), a major driver of top income responses to taxation could be a reduction in rent-seeking, for example a reduction in wage bargaining by CEOs. Our data, while rich, do not allow sufficient granularity to disentangle such channels.

Finally, we assess the implications of our estimates for tax revenue in the context of California Proposition $30 .^{6}$ A back of the envelope calculation based on our econometric estimates finds that the intensive and extensive margin responses to taxation combined to undo $45.2 \%$ of the revenue gains from taxation that otherwise would have accrued to California in the absence of behavioral responses within the first year and $60.9 \%$ within the first two years. The intensive margin accounts for the majority of this effect, while the extensive margin comprises $9.5 \%$ of this total response.

This paper proceeds as follows. In Section 2, we review related literature. In Section 3, we discuss the institutional setting, specifically California Proposition 30 and the federal tax changes that occurred at the same time. In Section 4, we describe the data. In Section 5, we describe the empirical methodology. Sections 6 and 7 present the extensive and intensive margin results respectively. Section 8 describes the policy implications of our extensive and intensive margin results. Section 9 concludes.

\section{Related Literature}

\section{2.a. Extensive Margin}

As Kleven et al. (2019) discuss in a recent survey, both lack of access to administrative data and identification challenges have to some extent constrained this literature. Literature on the behavioral response to taxation has aimed to analyze the response to taxable income as a whole (Feldstein 1999) under the notion that this is a sufficient statistic for the efficiency of the tax system. The availability of administrative micro-data, however, allows for the separation of the behavioral response into intensive and extensive margins, so that the behavioral impact of taxation on stayers can be separated from the impact on the decision to move out of a state or region.

Within the tax-induced mobility literature, several studies examine the issue in an international

\footnotetext{
${ }^{6}$ Our calculations bear on revenue implications with regard to the behavior of high-income taxpayers in the sense of taxpayers who file in the top Proposition 30 tax bracket in three consecutive years; the intensive margin analysis focuses on this group, and our extensive margin results are driven by these persistently high-earning taxpayers.
} 
context. Agrawal and Foremny (2019) find using administrative Spanish data that conditional on a decision to move, a one percent increase in the net-of-tax rate for a region relative to others increases the probability of moving to that region by 1.7 percentage points. Kleven et al. (2014) document an increased tendency of high earning foreigners to relocate to Denmark when a preferential top rate is introduced for all workers who have lived outside Denmark for at least three years, with estimates implying an elasticity of between 1.5 and 2; although Danish expatriates are afforded this same relocation tax incentive, the authors finds small elasticities for such workers. Focusing on specialized groups, Kleven, Landais and Saez (2013) find an elasticity of foreign European football players with respect to the net-of-tax rate of around 1, with domestic players significantly less sensitive to tax rates in the decision to leave their own country. Similarly, Akcigit, Baslandze and Stantcheva (2016) study the international mobility of inventors and also finds an elasticity of around 1 for foreign superstar inventors, but a negligible elasticity for domestic superstar inventors.

As discussed by Kleven et al. (2019), an emerging theme in the microeconometric literature on the migration response to taxation is that treatment effects are strikingly heterogeneous, and may depend on factors such as the size of the tax base, local amenities, and agglomeration effects. The above studies thus may not be informative for migration dynamics within the U.S. Several studies that have considered mobility across the U.S. states have resembled Kleven, Landais and Saez (2013) and Akcigit, Baslandze and Stantcheva (2016) in that they are focused on specialized groups. For example, Moretti and Wilson (2017) consider evidence from star scientists moving in response to taxation across state borders and find an elasticity with respect to the personal income tax of 1.8 and to the corporate income tax of 1.9. Coomes and Hoyt (2008) examine the propensity of in-movers to a metropolitan area to choose the part of that metropolitan area that is located in a lower tax state. Work by Feldstein and Wrobel (1998) and Leigh (2008) examines the question of the incidence of state income taxation, and in particular the mechanism whereby extensive margin movement could affect the net-of-tax wage, thus considering the somewhat separate question of whether extensive margin movement reduces the ability of state tax policy to redistribute income.

More general work on the extensive margin response to tax rates in the U.S. context includes work on millionaire migration such as Young et al. (2016) who use IRS data and argue that millionaire migration is a phenomenon of limited economic significance. Young and Varner (2011) consider micro-data from New Jersey around the imposition of a millionaire and find muted effects. Most recently, and closest to the part of our study that considers the extensive margin, Varner, Young and Prohofsky (2018) provide an empirical investigation of high-earner migration in the wake of tax increases using the same dataset as in our work. They find negligible effects of high-earner taxes on either the margins of inward or outward migration. We have little to add to their analysis on the in-migration margin. However, we provide new evidence of substantial high earner out-migration in response to rising state income taxes. 


\section{2.b. Intensive Margin}

Much has been written about the intensive margin response of taxable income to marginal net of tax rates. The classic study by Feldstein (1995) was the first to use panel data methods in this context, analyzing the Tax Reform Act of 1986 and finding elasticities from 1 to over 3 across specifications. Gruber and Saez (2002) use panel data methods in the context of the NBER Continuous Work History File from 1979-1990. This analysis yields a main estimate of 0.4. Kleven and Schultz (2014) in an important recent study find elasticities in the 0.2-0.3 range in Danish data. The datasets used in these papers give rise to the question of whether the studies reflect the responses of high earners as well as earners in the middle of the distribution. For example, the data used by Gruber and Saez (2002) contain only 13 observations of taxable income over 1 million dollars. In Kleven and Schultz (2014), the average taxpayer in this sample earns approximately 250,000 DKK (2013 values) annually, which is $\$ 44,642$ in 2013 dollars. As of 2018 , the cutoff for the top bracket in Denmark is 542,282 , which is $\$ 81,537$ in 2019 dollars.

Studies of high earners have been more challenging given the need for strong assumptions when working with aggregate data, or administrative data paired with appropriate empirical designs. Saez, Slemrod and Giertz (2012) employ public use data and aggregate methods to find elasticities for taxable income for the top $1 \%$ of U.S. earners with respect to the top marginal rate of between 0.58 and 1.71 between 1960 and 2006, depending on assumptions on time trends in the top $1 \%$ share of income. Using microdata from IRS Statistics of Income containing a substantial share of top earners, the paper analyzes the 1993 U.S. top rate increase from 31 percent to 36 or 39.6 percent and finds an elasticity of taxable income with respect to the marginal net of tax rate of $0.5-0.6$ using panel data methods. Piketty, Saez and Stantcheva (2014) present a theoretical framework in which high top marginal rates reduce income by muting the returns to non-productive bargaining efforts. Using microdata on CEO compensation, they find that the returns to U.S. CEOs from luck are stronger when top rates are low rather than high. Using a sample of international CEOs, they report elasticities of CEO pay with respect to top marginal rates of between 1.9 and 2 even after controlling for firm performance and CEO characteristics.

A recent literature has analyzed the impact of federal tax reforms from 2012-2013. Saez (2017) analyzes the intensive margin impact of the 2013 ATRA reform using aggregate data, finding a substantial time-shifting of income from 2013 into 2012 in response to the policy shift. Kawano, Weber and Whitten (2016) use federal tax return microdata, restricting the sample to taxpayers earning from $\$ 350,000$ to $\$ 650,000$, comparing taxpayers whose pre-ATRA incomes placed them just above and below the 2013 federal top rate hikes. They find mostly negligible intensive margin effects. 


\section{Institutional Setting}

\section{3.a. California Proposition 30}

In 2012 California governor Jerry Brown advocated and campaigned for the passage of Proposition 30, the "Schools and Local Public Safety Protection Act". This effort was based on a desire to preserve statewide education funding by instituting new tax increases on California's wealthiest taxpayers. The Proposition also sought to establish the Education Protection Account (EPA) within the state's General Fund, an account that would collect any new tax revenues that were derived from the newly passed ballot measure for the purposes of education spending.

In total, the Department of Finance believed that the new tax rates would result in an overall increase in tax revenues of $\$ 6$ billion annually between the tax years 2012-2013 and 2016-2017 with smaller amounts in 2011-2012, 2017-2018 and 2018-2019 as taxes are phased in and out. Initially in tax years 2011-2012 and 2012-2013, combined tax revenues were estimated to total $\$ 8.5$ billion. With this increase in tax revenue, there would be an additional $\$ 2.9$ billion dollars constitutionally required by Proposition 98 for the minimum funding of schools and community colleges. The remaining $\$ 5.6$ billion dollars in the General Fund would be appropriated for the purpose of closing the budget gap. ${ }^{7}$

The California Legislative Analyst's Office (LAO) mentioned the potentiality for a behavioral response in response to the newly instituted tax rates; however, the LAO never explicitly mentioned the degree to which (if at all) the possibility of a behavioral response factored into their projections. ${ }^{8}$

After the formal passage of Proposition 30, California's upper-income taxpayers saw three newly established personal income tax rates. The new tax brackets were the following:

- 10.3 percent tax bracket for single filers' taxable income between $\$ 250,001$ and $\$ 300,000$ and joint filers' taxable income between $\$ 500,001$ and $\$ 600,000$;

- 11.3 percent tax bracket for single filers' taxable income between $\$ 300,001$ and $\$ 500,000$ and joint filers' taxable income between $\$ 600,001$ and $\$ 1$ million; and

- 12.3 percent tax bracket for single filers' taxable income above $\$ 500,000$ and joint filers' taxable income above $\$ 1$ million.

These tax rates would initially be in effect for seven years (from tax year 2012 through tax year 2018). In addition to the increase in individual tax rates, there would also be an accompanying one-quarter percent increase in the state's sales tax rate, resulting in a sales tax rate of 7.5 percent (up from 7.25 percent), not including local sales tax rates which were subject to potential increases

\footnotetext{
7 "What Would Proposition 30 Mean for California?" pg. 1-2, see https://calbudgetcenter.org/wp-content/ uploads/120911_Proposition_30_BB.pdf

o"Proposition 30 Temporary Taxes to Fund Education. Guaranteed Local Public Safety Funding. Initiative Constitutional Amendment." https://lao.ca.gov/ballot/2012/30_11_2012.aspx
} 
upon the discretion of local governments. When factoring in the state and local sales tax rates in tandem, the average combined sales tax rate statewide was just above 8 percent. $^{9}$

Ultimately, the wealthiest one percent of California taxpayers, individuals making incomes of more than $\$ 533,000$, were expected to provide approximately 78.8 percent of the revenues raised by Proposition 30's tax increases, while California's top five percent of taxpayers, individuals making incomes of more than $\$ 206,000$, would contribute 81.2 percent of the revenues raised. The tax rate would amount to a 1.1 percent increase in income taxes for the top one percent of California taxpayers and an increase in 0.05 percent for the top five percent of California taxpayers. ${ }^{10}$

\section{3.b. 2012-13 Federal Tax Changes}

Simultaneous to the changes to state level taxes were notable changes to the federal tax system with the passing of the American Taxpayer Relief Act (ATRA) of 2012. While much of the bill extended provisions from tax bills of the past, there were nuanced yet significant changes that meaningfully impacted the wealthiest American taxpayers in particular. In this section we review these changes. To the extent federal changes affect federal MTR, it will affect relative tax costs of being in one state versus another. ${ }^{11}$

\section{3.b.1. Tax Rates and Brackets}

In 2001, President George W. Bush signed into law the Economic Growth and Tax Relief Reconciliation Act of 2001 (EGTRRA). One of the main provisions of the law was to phase-in tax cuts over the course of five years that would stabilize and become permanent. The rates of 28 percent, 31 percent, 36 percent, and 39.6 percent would eventually be reduced to 25 percent, 28 percent, 33 percent, and 35 percent, respectively, in 2006. However, the bill included a sunset provision that would ultimately end the tax cuts in $2011 .{ }^{12}$

With the passing of ATRA, the first three tax rates (25 percent, 38 percent, and 33 percent) were permanently extended. Additionally, this remained true for the top bracket of 35 percent, but only for individuals making less than $\$ 400,000$, heads of households making less than $\$ 425,000$, and couples making less than $\$ 450,000$. If taxable income exceeded those income levels, the rate would rise to the original pre-EGTRRA level of 39.6 percent. ${ }^{13}$ Furthermore, all of the taxable income thresholds for these tax rates would be indexed for inflation after 2013 .

ATRA also implemented an additional Medicare tax on employees of 0.9 percentage points on incomes over $\$ 200,000$ for single taxpayers and incomes over $\$ 250,000$ for married couples. This is in addition to the Medicare portion of the FICA tax, which is $1.45 \%$ for employers and $1.45 \%$ for

\footnotetext{
${ }^{9}$ Ibid. pg. 1

${ }^{10}$ Ibid. pg. 2

${ }^{11}$ Regarding the intensive margin, our empirical setting compares the evolution of income for California residents versus propensity score matched non-residents. A key identifying assumption is that the federal tax changes did not differentially affect California residents vs non-resident control observations.

12 "Economic Growth and Tax Relief Reconciliation Act of 2001" pg. 5, see https://www.govinfo.gov/content/ pkg/BILLS-107hr1836enr/pdf/BILLS-107hr1836enr.pdf

is "Tax Provisions in the American Taxpayer Relief Act of 2012 (ATRA)", pg. 5 see https://tpc.io/2sQv0zE
} 
employees. The total Medicare tax therefore became 3.8\%, of which $2.35 \%$ is statutorily paid by the employee. A self-employed individual would pay the entire $3.8 \%$.

\section{3.b.2. Capital Gains}

In 2003, Congress continued to make substantive changes to the U.S. tax system by passing the Jobs and Growth Relief Act of 2003 (JGTRRA). As a consequence of the bill, realized capital gains received by individual shareholders saw decreases in tax rates to which they were subject. More specifically, realized capital gains that were initially subject to a tax rate of 10 percent (in brackets where the ordinary income tax was higher than 15 percent) and 20 percent (in brackets where the ordinary income tax was higher than 15 percent) were lowered to 5 percent and 15 percent, respectively, through 2007 and zero and 15 percent in 2008. ${ }^{14}$

ATRA, acting in the same fashion as the bill had done with respect to tax rates, permitted the original decreases in the capital gains tax rates to remain permanent. However, this would not be the case for those taxpayers who fell into the reestablished 39.6 percent tax bracket. For those taxpayers, the tax rate on capital gains reverted to its original, pre-ATRA value of 20 percent. ${ }^{15}$

\section{3.b.3. Qualified Dividends}

The JGTRRA of 2003 also established new tax rates for qualified dividends. These rates followed the same 5 percent and 15 percent structure as the capital gains tax rates. However, with the passage of ATRA, the rates were slightly altered to continue to mirror the new capital gains tax rate structure (0 percent, 15 percent and 20 percent). ${ }^{16}$

\section{3.b.4. Alternative Minimum Tax Provisions}

ATRA also provided relief to middle income earners by raising the alternative minimum tax (AMT) exemption limit from $\$ 45,000$ for married couples ( $\$ 33,750$ for singles) and certain personal credits to $\$ 78,750$ for married couples ( $\$ 50,600$ for singles) For 2013 and onward, the AMT exemption would be indexed for inflation. However, these changes did not extend to higher income earners. Under ATRA rules, the AMT imposed a 26 percent tax on taxable income for AMT purposes up to $\$ 175,000$. Any amount greater than $\$ 175,000$ would be subject to a 28 percent rate. ${ }^{17}$

\section{3.c. Interaction between State and Federal Taxes}

Determining whether confluences of legislative action on state and federal levels would have mitigating or accelerating effects on migration requires understanding the ways these legislative provisions

\footnotetext{
14 "Bush Administration Tax Policy: Introduction and Background" pg. 1292, see https://www.brookings.edu/ wp-content/uploads/2016/06/20040913galeorszag.pdf

${ }_{15}$ "Tax Provisions in the American Taxpayer Relief Act of 2012 (ATRA)" pg. 5, see https://tpc.io/2P2IKcq

${ }^{16}$ Ibid.

${ }^{17}$ Ibid, pg. 6
} 
interact with one another. As far as ATRA and Proposition 30 are concerned, the newly established tax rates and their interaction with the newly instituted "Pease Provision" is perhaps the most important element.

As discussed in depth by Saez (2017), ATRA introduced significant changes with respect to itemized deductions. Through the new provision, the Pease limitation, itemized deductions were reduced by 3 percent of an individual's AGI when that income exceeded more than $\$ 300,000$ for couples ( $\$ 250,000$ for singles and $\$ 275,000$ for head of household filers) for up to 80 percent of the itemized deduction. The addition of this provision ostensibly increased the marginal tax rate of high-income earners by 1.2 percent $(3 \% \times 39.6 \%=1.2 \%)$. However, when factoring in the new state tax increase on the top marginal tax rate, an individual's marginal net tax rate is effectively lower as a result. Consider, for example, an individual in the top tax bracket on both the state and federal level living in California in 2013. This individual's marginal tax rate on the federal level would be 39.6 percent while on the state level the state rate would be 13.3 percent. The top marginal tax rate on income at the federal level in 2013 is $39.6 \%$, the taxpayer share of the health care marginal rate is $2.35 \%$, and the state rate in California is $13.3 \%$. The effective federal marginal rate is $39.6 \times(1-.133+.03)=35.52$, where $3 \%$ is added back due to the Pease Provision's limits on itemized deductions. ${ }^{18}$ Under a no-Proposition 30 counterfactual, the effective federal marginal rate is $39.6 \times(1-.103+.03)=36.71$. Thus, under Proposition 30 the marginal net of tax rate is

$$
100-35.52-13.3-2.35=48.83
$$

whereas without it would be

$$
100-36.71-10.3-2.35=50.64
$$

\section{3.d. Polling Data and Proposition 30}

Starting at the time of the March 2012 request for the ballot title for Proposition 30, there was a lively public debate regarding the measure. Almost immediately, polls began to gauge public sentiment regarding the ideas in the proposition. On March 14, the firm Greenberg Quinlan Rosner conducted a poll in which California residents supported the measure by a 64 percent to 33 percent margin. While this margin would wane to some extent in coming months, support for the proposition prevailed in every poll save for a SurveyUSA poll in October of 2012; this same poll had 29 percent of its respondents identify themselves as "Undecided," 15 points higher than in any of the other polls conducted concerning Proposition 30. Furthermore, those in favor of the measure averaged a +12 point margin over those who opposed when analyzing the results of all of the polls in the lead up to the vote. ${ }^{19}$

At the same time, both proponents and opponents of the measure mobilized state-wide fundrais-

\footnotetext{
${ }^{18}$ Note that the Pease Provision was repealed by the Tax Cut and Jobs Act of 2017, effective for the 2018 tax year. 19 "California Proposition 30, Sales and Income Tax Increase (2012)," see https://ballotpedia.org/California_ Proposition_30,_Sales_and_Income_Tax_Increase_(2012)
} 
ing efforts. A total of $\$ 120,500,000$ was donated relating to Proposition 30. Of this total amount, $\$ 67,100,000$ (55 percent) of the funds were donated in favor of the measure's passage, compared to the opposition's $\$ 53,400,000$ (45 percent). ${ }^{20}$ The majority of anti-Proposition 30 donations derived from one donor - Charles Munger, Jr. Munger donated $\$ 35,075,000$, or approximately 66 percent, of all donations in opposition to the measure. Anti-Proposition 30 donations in general represented the interests of high earners. In total, the top three donations (outside Munger, $\$ 11,000,000$ came from Americans for Responsible Leadership and $\$ 1,100,000$ came from William Oberndorf), accounted for 88 percent of all donations for the opposition. ${ }^{21}$

Donations in favor of the proposition derived from a broad coalition representing decidedly less moneyed interests. The largest such donation was $\$ 11,439,297$ from the California Teachers Association, which amounted to only 17 percent of the total donation pool. The next-largest donations were $\$ 10,746,928$ from Service Employees International Union/California State Council of Service Employees Issues Committee and \$5,089,646 from Democratic State Central Committee of California. ${ }^{22}$

Overall, as is clear from the discussion of polling and political donations, Proposition 30 was a first order issue in both California popular and political circles during much of 2012. It was clear early on in 2012 that the Proposition had a substantial chance of passage, leading some interests representing high-earning California residents to take political action against it. In general, this suggests that even as of early 2012 many in California may have been adjusting their behavior in anticipation of the passage of Proposition 30.

\section{Data}

This paper uses administrative data from the California Franchise Tax Board (FTB). The data file contains the universe of California tax returns from 2000-2015, although income items are only complete for 2000-2014. ${ }^{23}$ These tax returns include both the filings of California residents, nonresidents and partial-year residents. Non-residents and partial-year residents are coded identically in the data and thus from this point forward will be referred to interchangeably.

From these returns, we have population-level coverage of certain variables measured from the California Form 540. Variables for which we have full coverage include Taxable Income and California AGI, Federal AGI, Capital Gains (we observe the sum of long term and short term capital gains), Interest, and Dividends. ${ }^{24}$ Appendix B shows the components of "Total Income," which is then adjusted to AGI through subtractions. AGI then becomes taxable income by removing deductions. State and federal quantities differ due to state and federal specific adjustments. For example, state and local taxes could at the time still be itemized in deductions from federal AGI.

${ }^{23}$ The file we received also contained some data from 2016 filings, but we determined that the filings were still incomplete for that tax year.

${ }^{24}$ Data for Interest and Dividends are missing for 2009, and capital gains data is missing for 2015
} 
Income variables in the data are measured at the household level, or more precisely the level of the primary taxpayer in a household. Three filing statuses account for the near-universe of filings: single, married joint-filers, ${ }^{25}$ and head of household. ${ }^{26}$ In the case of married joint-filers, spousal incomes are aggregated together so that it is not possible to attribute income to one spouse or another. The FTB designates one spouse the "primary taxpayer" and the other a "redundant spouse," and the data include identical records for each party reflecting household quantities. All of our analysis is conducted at the level of a primary taxpayer - that is, a household. However, when appropriate we use the comprehensive panel nature of the data; for instance, when constructing out-migration variables, a taxpayer who today is a primary taxpayer and tomorrow is a redundant spouse is not defined as an out-migration event. We observe taxpayer-level demographic information on marital status, dependents, and for years 2010 and after we observe taxpayer age.

All dollar amounts are inflation-adjusted to 2015 dollars using inflation factors from the FTB (see Appendix Table A1 for these inflation factors). Table 1 contains summary statistics for the full sample, 2000-15. Lastly, to impute marginal tax rates and taxes paid, we follow the literature in using version 27 of the TAXSIM calculator provided by the NBER. See Feenberg and Coutts (1993) for a description of TAXSIM. We use taxpayer-level TAXSIM computations only in our assessment of the average-tax-rate effects of Proposition 30 to inform the extensive margin analysis.

The TAXSIM calculations were not done using the standard TAXSIM online interface due to contractual limitations on the use of the data. Instead, we obtained the TAXSIM FORTRAN archive directly from the NBER and performed computations locally on the FTB data. These computations at the microdata level are used only in the context of assessing the incentives for California taxpayers to out-migrate driven by either Proposition 30 or the 2018 Federal TCJA.

\section{Methodology}

\section{5.a. Extensive Margin Responses: Migration}

Our ability to detect a larger out-migration effect as compared to the work of Varner, Young and Prohofsky (2018) owes primarily to our use of a more general definition of out-migration. In the following we will define this measure and demonstrate its validity and quantitative importance for high-earners.

\section{5.a.1. Measuring Out-Migration}

To define an out-migration event, Varner, Young and Prohofsky (2018) identify cases in which a taxpayer in three consecutive years $t, t+1, t+2$ displays the following behavior:

- Year $t$ : Files as a California Resident

\footnotetext{
${ }^{25}$ In nearly all cases it is sub-optimal to file separately when part of a married couple.

${ }^{26} \mathrm{Head}$ of Household is for unmarried taxpayers who manage the upkeep of a home for a qualified set of individuals.
} 
- Year $t+1$ : Files as a California Non-Resident or Partial Year Resident

- Year $t+2$ : Does not file

We agree that such behavior patterns constitute migration, and term this phenomenon "full out-migration" occurring in year $t$. However, this definition may under-count out-migration in the following sense. Some California households may have California-based sources of income which are not easy to immediately relocate. Thus, even if the household for all practical purposes has relocated to another state, it may still file taxes in California due to these income sources. For example, a household may own properties other than its residence from which it derives rental income. Further, it is likely that this scenario is particularly relevant to high-income households. Thus, we consider the additional channel of migration, in which a taxpayer in three consecutive years $t, t+1, t+2$ displays the following behavior:

- Year $t$ : Files as a California Resident

- Year $t+1$ : Files as a California Non-Resident or Partial Year Resident

- Year $t+2$ : Files as a California Non-Resident or Partial Year Resident

We refer to this sequence of events as "partial out-migration" occurring in year $t$. While we have provided an intuition for this definition, we proceed to validate this definition in the data, as well as the quantitative relevance of this out-migration margin.

First, we show that such events fit the intuitive definition of a migration. Figure 2 plots the cumulative ratio of California $\mathrm{AGI}^{27}$ to Federal AGI amongst all partial out-migrations of top-bracket taxpayers ${ }^{28}$ which occur in years 2000-09, and separately for partial out-migrations occurring in year 2012. We rely on this ratio to measure the fraction of total taxpayer income derived from California-based sources, because we directly observe both the numerator and denominator in the data (we do not observe state and federal quantities simultaneously for any other component of income, such as taxable income). The figure demonstrates that among partial migration events occurring in 2012, a top-bracket household decreases its California to Federal AGI by $83.6 \%$ by 2014. This effect is nearly identical during years 2000-09. Appendix Figure A1a shows that the dynamics of this ratio are driven by a drop in the level of California AGI, whereas Federal AGI does not appreciably drop after the partial out migration. Appendix Figure A1b shows the AGI levels.

Secondly, we check whether such events are quantitatively important in the data. Appendix Table A2 shows, over the 2000-09 period, percentage rates of out-migration for various income bins. This tables makes clear that "full out migration" is the dominant mode of out-migration for taxpayers in the $9.3 \%$ bracket, but that "partial out-migration" is the primary mode of outmigration observed amongst high-earners.

\footnotetext{
${ }^{27}$ California AGI differs from Federal AGI in two ways: (a) it includes only California source income; and (b) California and Federal law differ slightly in their definitions of AGI.

28 "Top-bracket" refers to households which are in the top tax bracket under Proposition 30 policy, based on inflation-adjusted taxable income
} 


\section{5.a.2. Out-Migration Regression Specification}

We adopt a time-disaggregated differences-in-differences regression specification to evaluate the impact of Proposition 30 on out-migration. First, we restrict the sample to CA-resident tax returns from years 2000-2013 which are at the post-reform 9.3\% tax bracket. The $9.3 \%$ bracket forms the "control" group. We allow for three "treatment" groups: those in the post-reform 10.3\%, 11.3\%, and $12.3 \%$ tax brackets. The bracket index $b$ runs through the set $b \in\{9.3 \%, 10.3 \%, 11.3 \%, 12.3 \%\}$ in the baseline specification, with alternative specifications including finer cuts of the top income bracket. The dependent variable $\mathbf{1}\{\text { Move Out }\}_{i t}$ indicates that taxpayer $i$ engages in full outmigration or partial out-migration beginning in year $t$, as defined above. We also consider each source of out-migration separately. We use years 2000-10 as the "pre period," and estimate effects separately for years 2011-13.

$$
\begin{gathered}
\mathbf{1}\{\text { Move Out }\}_{i t}=\alpha_{t}+\alpha_{\text {Marital Status }}+\mathbf{1}\{t \leq 2010\}_{i t} \times \sum_{b} \beta_{b, P r e} \mathbf{1}\{\text { In Bracket b at Year } \mathrm{t}\}_{i t} \\
+\sum_{x=2011}^{2013} \mathbf{1}\{t=x\}_{i t} \times \sum_{b} \beta_{b, x} \mathbf{1}\{\text { In Bracket b at Year x }\}_{i t}+\phi^{\prime} X_{i t}+\varepsilon_{i t}
\end{gathered}
$$

All specifications include year and marital-status fixed effects. We run the regressions either with an empty covariate vector $X_{i t}$, or allow this vector to include the log of taxable income along with fixed effects for 100 bins of taxable income. The baseline regression is weighted by taxable income (inflation adjusted so that weights are consistent across years), so that the coefficients are interpreted not as the fraction of taxpayers moving out, but the fraction of taxable base moving out.

Finally, we stop the sample at the outward migration that occurred in 2014 (2013 resident base year), as going forward requires certainty that 2016 data are complete. Tax returns from highearners take longer to process, and this may bias the sample. Practically this choice does not affect the estimates because we estimate year-by-year coefficients.

\section{5.a.3. Incentives to Move}

Our methodology aims to estimate the abnormal rate of out-migration in the years surrounding the passage of Proposition 30 in different categories of taxpayers. A naïve interpretation of our results would state that they are driven by a three-point hike in the marginal income tax rate of top bracket taxpayers, or two and one point hikes for lower brackets. Such statements would be misleading in two ways. First, extensive margin decisions respond to changes in average tax rates (not marginal rates). Secondly and more importantly, even it were the case that these two rates were equal - as may approximately be the case for very high earners - the deductibility of state taxes paid from federal taxable income leads the effective increase in tax rates due to Proposition 30 to be lower than $3 \%$. 
To illustrate the issue, suppose that marginal rates are equal to average rates and that state rates are $10.3 \%$ and federal rates are $40 \%$. The taxpayer's cumulative tax rate is $10.3 \%+(1-.103)$ $\times 40 \%=46.18 \%$. If state rates are raised to $13.3 \%$, the taxpayer's cumulative rate is $47.98 \%$ by the same logic, which amounts to a net tax increase of $1.8 \%$.

Complicating matters further, federal rates rose between 2012 and 2013, which would further mitigate the change in average tax rates for those 2012 California residents contemplating outmigration. This implies that in the absence of a federal tax increase any out-migration incentives would in fact have been stronger.

To precisely understand how Proposition 30 altered incentives to move out of California, we undertake the following exercise. We fix taxpayer behavior at 2012 levels. We first use TAXSIM to compute the difference in the average tax rate each taxpayer $i$ would face if she moved to a state outside California $i$, relative to California, under 2011 tax policy: ${ }^{29}$

$$
\left\{T_{2011}^{C A}\left(z_{i, 2012}\right)-T_{2011}^{S}\left(z_{i, 2012}\right)\right\}_{\forall i, S \neq C A}
$$

This quantity represents for each taxpayer the pre-Proposition 30 tax gains to moving out of California. ${ }^{30}$ Next, we compute this same quantity for 2012 tax policy:

$$
\left\{T_{2012}^{C A}\left(z_{i, 2012}\right)-T_{2012}^{S}\left(z_{i, 2012}\right)\right\}_{\forall i, S \neq C A}
$$

Federal tax policy did not change substantially from 2011 to 2012. On the other hand, TAXSIM's 2012 policy incorporates Proposition 30 due to its retroactive nature. Thus, this quantity can be interpreted as the post-Proposition 30 tax gains to moving out of California, before the 2012-13 federal tax increase. Finally, we repeat the computation for 2013 tax policy, computing:

$$
\left\{T_{2013}^{C A}\left(z_{i, 2012}\right)-T_{2013}^{S}\left(z_{i, 2012}\right)\right\}_{\forall i, S \neq C A}
$$

This quantity represents for each taxpayer the post-Proposition 30, post 2012-13 federal policy shift gains to moving out of California.

To systematically summarize the results of this exercise, we first disaggregate taxpayers $i$ into groups $B$ based on their 2012 income: those in the $10.3 \%$ bracket, the $11.3 \%$ bracket, $12.3 \%$ bracket earning under $\$ 2$ million, $\$ 2-\$ 5$ million, and over $\$ 5$ million. For each such group, we report first how Proposition 30 altered incentives to leave California, averaged over individuals and destination states:

\footnotetext{
${ }^{29}$ To render average tax rates comparable across states, we fix as the denominator 2012 California Taxable Income. This is not ideal, but is advantageous compared to either using raw amounts of taxes paid (which is difficult to interpret), state-by-state taxable income (this quantity cannot be computed in zero-tax states like Texas and Nevada), or a measure of federal taxable income (which will be different under different amounts of state taxes paid).

${ }^{30}$ We note that this calculation disregards movements out of America, but we will show in the results that this does not represent a sizeable share of Proposition-30 driven out-migration.
} 


$$
\left[\frac{1}{\sum_{i \in B, S \neq C A} 1}\right] \sum_{i \in B, S \neq C A}\left[T_{2012}^{C A}\left(z_{i, 2012}\right)-T_{2012}^{S}\left(z_{i, 2012}\right)\right]-\left[T_{2011}^{C A}\left(z_{i, 2012}\right)-T_{2011}^{S}\left(z_{i, 2012}\right)\right]
$$

We report these averages in Table 2 in the "Only Prop 30" column. Note that if $T_{2012}^{S}\left(z_{i, 2012}\right)=$ $T_{2011}^{S}\left(z_{i, 2012}\right)$ - that is, the destination state does not change tax policy between 2011 and 2012 the quantity collapses to $T_{2012}^{C A}\left(z_{i, 2012}\right)-T_{2011}^{C A}\left(z_{i, 2012}\right)$. Thus, we do not disaggregate these averages across destination states, as very few states other than California changed tax policy between 2011 and 2012. These figures show that even for very high earners earning over $\$ 5$ million dollars in 2015 dollars, the effective increase in average tax rate is closer to $2 \%$ than to the top marginal rate increase of $3 \%$. This is due both to the federal deductibility of state taxes and the discrepancy of average and marginal tax rates.

We then account for how this increase in move-out incentives is altered by the concurrent 201213 increase in federal tax rates, which induce variation in cross-state movement incentives due to the interaction of the federal policy shift with the existing state of tax deductions in non-California states. That is, we compute disaggregated averages of the form:

$$
\left[\frac{1}{\sum_{i \in B, S \neq C A} 1}\right] \sum_{i \in B, S \neq C A}\left[T_{2012}^{C A}\left(z_{i, 2013}\right)-T_{2013}^{S}\left(z_{i, 2012}\right)\right]-\left[T_{2011}^{C A}\left(z_{i, 2012}\right)-T_{2011}^{S}\left(z_{i, 2012}\right)\right]
$$

We report such averages in the "Prop 30 + Federal Tax Increase" columns of Table 2. To provide a broad picture of this heterogeneity, we split the destination states into three groups in the latter columns of Table 2 (1) zero-tax states, which have zero state income taxes in 2012 and 2013; (2) non-zero tax states which tax income but do not change tax policy between 2012-13; (3) Iowa, Kansas and Maine are reported separately because these states enacted tax cuts between 2012 and 2013, thus increasing the incentive to move there. Lastly, in the table calculations we omit Minnesota, which raised the top state income tax rate from 7.85 to $9.85 .{ }^{31}$ Figure 1 provides a visualization by state of average rate increases for taxpayers in the $\$ 5+$ Million income bin.

The largest change in marginal gains from out-migration in this calculation are realized by moving to the states that cut taxes. However, outside these cases, we see that empirically the most additional tax savings over and above pre-existing gaps are realized by relocating to previously lowtax states such as Texas and Nevada, as opposed to states which previously had non-zero income taxes. This occurs in the data because of the Pease Provision of ATRA, which as explained above included a phase-out of itemized deductions.

It is theoretically ambiguous whether out-migration in response to a California tax increase should flow more strongly to states with higher marginal increases in tax savings, such as Kansas, Maine, and Iowa, or whether migration should flow toward the states with all-in highest savings

\footnotetext{
${ }^{31}$ Kansas and Maine explicitly cut rates, while Iowa held its rates constant but reduced its definition of taxable base
} 
in taxes, which are the zero-tax states. The latter behavior would be rationalized in a model in which taxpayers only value tax savings in location decisions, in which case the salient decision criterion is the minimum average tax rate obtainable by moving to any state within the U.S. The former behavior could be rationalized in a model in which taxpayers have very strong idiosyncratic destination preferences; in an extreme case suppose each taxpayer can only move to one destination state at random (perhaps due to social networks or an employment situation), in which case the decision criterion is the minimum average tax rate obtainable by moving to that one state. In this case and given random preferences, states such as Kansas should see higher out-migration from California than would a zero-tax state like Texas.

We note that while all analysis here is framed in terms savings in the average tax realized from leaving California, it can be considered equivalently as gains in the net of tax rate.

Logs. Much of the literature on the extensive margin response to taxation uses logs of the net of tax rate, instead of levels, as the independent variable of interest (i.e. Kleven et al. 2014. Moretti and Wilson 2017, Agrawal and Foremny 2019). Appendix Table A3 shows the analysis in terms of logs of the net of tax average rate. Note here that the incorporation of the federal tax increase from 2012-13 in fact can lead to higher increases in the log net of tax rate benefits from leaving California. This is because, although the levels difference argument from above carries through, differences in logs are approximately percent differences. The large federal tax increase leads all net of tax rates to fall, leading to the magnification of any percent difference. Based on these calculations, the average incentive to move is approximately equal for states with non-zero taxes and no tax changes when incorporating the federal tax rise, but it is $38 \%$ higher for zero-tax states with the federal tax change.

\section{5.b. Intensive Margin Methodology}

Our focus with regard to the intensive margin impact of taxation is estimating the effect of the California tax reform, attempting to difference out behavioral responses to the federal tax reform. We do this because the federal tax reform affects all U.S. citizens and thus it is difficult to construct a credible counterfactual group. Existing studies largely attempt to use lower-income groups to control for the income trends in top-brackets (see Kawano, Weber and Whitten 2016 in the context of the 2013 federal tax reform). In contrast, our approach is to focus on state tax reforms for which we have cross sectional variation for taxpayers of comparable earnings status.

\section{5.b.1. Differences in Differences}

To study the causal effect of the California tax reform (and to difference out income re-timing from 2013 into 2012 resulting from the federal tax increase), we use the following empirical strategy. We define the "treatment group" of taxpayers as those who from 2009 to 2011 filed as California residents, and further who for each year earned taxable income which placed them in the range of the top-bracket as newly introduced by California Proposition 30. Finally, we require that each 
"treated" taxpayer file as a California resident through 2014. The motivation for defining treatment status based on a measure of persistent high-earnings is the well-known issue in the literature on intensive margin responses to taxation that high incomes are strongly mean reverting (see for example Weber 2014). For example, in our setting of California, incomes may mean revert due to startup IPOs or other liquidity events.

To identify the causal response of such taxpayers to California Proposition 30, we need a suitable counterfactual. Our "control group" is defined as those taxpayers who file non-resident returns in California in every year from 2009 to 2014, and whose inflation-adjusted California taxable income ${ }^{32}$ places them in the top California bracket (as introduced under Proposition 30) for 2009-11. Such taxpayers are not subject to California taxes except for their California source income; Appendix Table A4 shows that such filers on average have a California AGI to Federal AGI ratio of between $4.8 \%$ and $7.5 \%$ over the course of the 2009-14 period. On the other hand, California residents are subject to state income taxation on all income regardless of its geographic source.

This setup suggests a differences-in-differences strategy. We show the raw plots of this differencesin-differences for levels and logs of taxable income and AGI in Appendix Figure A9, As is evident in this figure, and from the tabulation in Table 6, non-resident filers in the control group display substantially higher earnings than do residents. Thus, covariate imbalance is severe and is a major endogeneity concern.

\section{5.b.2. Differences in Differences with Matching}

To address this concern, we use as a pre-processing step a simple matching procedure, making advantageous use of the substantial size of both the California high-income tax filing sample and of the non-resident filer sample. Our procedure matches with replacement on propensity scores calculated using a logistic regression on 2009-10 total AGI, taxable income, and capital gains, and matches with replacement. This approach retaining the full "treatment" group while re-weighting the "control" group to achieve better covariate balance. The procedure enables us to recover an average treatment effect on the treated, where the "treated" are persistently high-earning California residents in our particular fashion.

We conduct matching in two ways. First, we use the full set of non-resident controls as matching candidates. Secondly, as a robustness check, we use only taxpayers filing in 2011 from states with similar state tax rates to California. We define this group of states as Hawaii (11\% top rate), Oregon (9.9\% top rate), Minnesota (9.85\% top rate), Iowa ( $8.98 \%$ top rate), New Jersey ( $8.97 \%$ top rate), Vermont ( $8.95 \%$ top rate), District of Columbia ( $8.95 \%$ top rate), and New York ( $8.82 \%$ top rate). To motivate this robustness check, suppose in the initial procedure we match a California taxpayer to a Texas resident filing as a California non-resident with the same pre-period income. If the Texan were transplanted to California, she would presumably earn less given the higher marginal tax rate in California, which contaminates the matching. That is, we would like to match on pre

\footnotetext{
${ }^{32}$ That is, their California taxable income if they were California residents, in which case their entire income base would be subject to California taxation. This quantity is a variable in our dataset.
} 
period incomes under identical tax regimes. Using states with high tax rates in the pre-period helps alleviate this concern, and yields more conservative estimates that we rely on in our elasticity calculations.

After matching, we apply a year by year differences-in-differences estimation to adjust for any remaining differences in covariate balance across the matched treatment and control groups. As discussed in Imbens and Wooldridge (2009), while the unconfoundedness assumption justifying the matching procedure cannot be directly tested, its plausibility can be assessed through placebo-style tests. In our setting, while 2009-2011 covariates are predetermined from the viewpoint of the tax policy treatment, we only match on 2009-10 covariates. This allows us to examine outcomes in 2011 as a placebo-style test. If unconfoundedness were true, we would not expect the matched control and treatment groups to display systematic differences in 2011. As such, in our differences-in-differences regression we take the pre-period as 2009-10, and estimate "treatment effects" separately for 20112014. If unconfoundedness holds, we do not expect to see a positive and statistically significant coefficient for 2011. The estimating equation is as follows.

$$
z_{i t}=\alpha_{i}+\alpha_{t}+\alpha_{\text {Marital Status }}+\sum_{x=2011}^{2014} \mathbf{1}\{t=x\}_{i t} \times \mathbf{1}\{\text { California Resident }\}_{i t} \times \beta_{t}+\varepsilon_{i t}
$$

where $\beta_{2011}$ is akin to a placebo test and $\beta_{t}$ for $t \in\{2012,2013,2014\}$ are the coefficients of interest.

As an alternative specification, we also estimate a dynamic event study regression Borusyak and Jaravel (2016), de Chaisemartin and D'Haultfœuille (2018). We use 2011 as the "reference period" (i.e. pre period). This enables us to leave 2009 and 2010 to estimate "treatment effects" in the pre period to test for parallel trends. Specifically the dynamic event study estimation equation is:

$$
z_{i t}=\alpha_{i}+\alpha_{t}+\alpha_{\text {Marital Status }}+\sum_{x \in\{2009,2010,2012,2013,2014\}} \mathbf{1}\{t=x\}_{i t} \times \mathbf{1}\{\text { California Resident }\}_{i t} \times \beta_{t}+\varepsilon_{i t}
$$

Building on this specification, we implement the "honest approach to parallel trends" approach of Rambachan and Roth (2019). We estimate fixed length confidence intervals (FLCIs) under the single-parameter $(M)$ approach. $M$ is the single-parameter that determines the degree of possible nonlinearity of parallel trends, serving as an upper bound to the extent to which differential trends can change within periods. We implement this method using the publicly available HonestDiD R package.

Regression specification and income re-timing. Our estimating equation differs from the classical equation in the literature estimating intensive margin responses to tax policy using microdata, which runs the year-on-year log difference in income variables on the left hand side. ${ }^{33}$

\footnotetext{
${ }^{33}$ See Gruber and Saez (2002) for a classic treatment, and Kawano, Weber and Whitten (2016) in the context of the 2013 federal tax change.
} 
We use this specification because it enables a cleaner treatment of federal income re-timing than the classic approach.

To see this, consider the following framework. Suppose that observed income in year $t$ for taxpayer $i$ is $z_{i t}\left(W_{i t}\right)$ where $W_{i t}$ the treatment is binary: 0 corresponds to tax policy prior to the reform, while 1 corresponds to the post reform tax policy. That is, we observe $z_{i t}(0)$ in the absence of Proposition 30, and $z_{i t}(1)$ under Proposition 30. This potential outcomes formalism encapsulates all behavioral responses (including "non-real" responses such as tax base shifting) except for income re-timing responses. For such responses, let $F_{i}>0$ denotes income shifted from 2013 into 2012 in response to the federal tax reform. Explicitly, in the absence of Proposition 30 the observed sequence of incomes for taxpayer $i$ is

$$
\left\{z_{i, 2009}(0), z_{i, 2010}(0), z_{i, 2011}(0), z_{i, 2012}(0), z_{i, 2013}(0), z_{i, 2014}(0)\right\}
$$

In reality we observe the following sequence:

$$
\left\{z_{i, 2009}(0), z_{i, 2010}(0), z_{i, 2011}(0), z_{i, 2012}(0)+F_{i}, z_{i, 2013}(1)-F_{i}, z_{i, 2014}(1)\right\}
$$

Given this setup, any log-difference variables involving 2012 or 2013 are all mis-measured due to front loading. We note that the year on year difference 2012-13 double-counts the front-loading quantity, and any longer difference involving 2012 or 13 (such as a 2011-13 difference) will still be contaminated by the income re-timing.

Front loading of this type is empirically relevant. For example, Saez (2017) uses aggregate public-use data to infer substantial front loading from 2013 into 2012 in response to the federal tax reform. We corroborate this in our data.

Appendix Figure A2 shows the forward log change in taxable income for each of 2000 taxable income buckets for each tax year over 2009-2014. The change for 2012 to 2013 is very pronounced at the very top of the income distribution. However, Appendix Figure A3 shows again that this apparent "effect" disappears when averaging across 2-year periods.

Working in levels instead of differences allows a year-by-year comparison of income levels and avoids the problems in interpretation created by using log differences in the presence of front loading. We also note that any 2012 treatment effects we estimate in the context of the California Proposition 30 treatment effect do not have a re-timing interpretation because the California policy was retroactive to 2012. We do not expect a 2011 front loading response as Proposition 30 was not widely expected or discussed as of 2011.

\section{Extensive Margin Response}

Figure 3 shows the main graphical results on out-migration, with the years in the $\mathrm{x}$-axis representing the base year and the departure is evidenced in both of the following years, either as move to nonresident status for both years or a move to non-resident and then to non-filer. That is, the value 
corresponding to the 2012 point on the x-axis is the hazard rate based on 2013 and 2014 for taxpayers who were still California residents in 2012.

The top two graphs show taxable-income weighted out-migration probabilities by year and tax bracket for taxpayers who filed as California residents in year $t$, disaggregated across the two ways that taxpayers leave the state: (i) resident to non-resident to non-resident; and (ii) resident to non-resident to non-filer. The bottom panel shows the combined effect of both types of departure. In order to examine how the departure rates vary at different points of the income distribution for high earners, we decompose the $12.3 \%$ bracket into three subgroups: $12.3 \%$ under $\$ 2$ million, $\$ 2-\$ 5$ million, and greater than $\$ 5$ million. ${ }^{34}$

The top graph shows a sharp uptick in taxpayers who earned $\$ 5$ million or more in 2012 leaving the state after 2012 for multiple years of non-resident tax filings, from a rate of around $1.2 \%$ in the prior years to over 1.6\% in the year 2012 to 2013. Taxpayers earning between $\$ 2$ million and $\$ 5$ million display a similarly large effect. Figure 3 corroborates the aggregated statistics from Appendix Table A2 in demonstrating that this tax structure of departure is substantially more common for this group than moving from resident to non-resident to non-filer, presumably given the fact that most very high earners have some remaining California source income and then would have to file a California tax return even as a non-resident for several years after departure. As discussed in Section 5.a.1. this mode of migration leads to an outflow of $83.6 \%$ of taxable base within two years. The middle graph shows an increase in full out migration as well, although smaller. Overall, the bottom graph shows that when the departure structures are combined, there is a clear increase from a $1.5 \%$ departure rate after the 2011 tax year to a $2.125 \%$ departure rate after the 2012 tax year for taxpayers with more than $\$ 5$ million in taxable income. Similar patterns are seen in the $\$ 2-\$ 5$ million range of broadly comparable magnitude. We note that there is no evidence of pre-trends in the departure rates for the taxpayers in the highest income categories.

Table 3 provides regression estimates of the magnitude of the out-migration effect, showing estimates of the baseline equation 1. The estimates from column (1) show that, relative to the 2000-10 period, we cannot detect statistically or economically significant deviations in the rate of migration in 2011-12 for the newly introduced top bracket, but from 2012-13 California loses 0.8\% of the taxable base in this income range. Column (2) demonstrates that the inclusion of log income and fixed effects for 100 income percentiles as income controls does not diminish these results. The remaining columns of the table decompose mover types into those who file the next two years as non-resident versus those who file for one year as a non-resident and then do not file. More than half of the effect $(0.5 \%$ of the $0.8 \%)$ is concentrated in taxpayers moving from resident status into persistent non-resident filing.

Table 4 shows unweighted estimates with more granular income bins, showing that the outmigration effect is indeed concentrated in higher-earning taxpayers. This table directly mirrors the graphs in Figure 3. Investigating treatment heterogeneity in Appendix Table A5, we find

\footnotetext{
${ }^{34}$ The tax brackets or taxable income bins are assigned based on 2012 rules and income, with income indexed to inflation to lead and lagged years use California FTB inflation factors.
} 
some evidence that 2012 treatment effects may be up to twice as large for single households as for married households, perhaps indicative of the greater ease with which a single-individual can make a decision to move states. Appendix Figures A4 and A5 show heterogeneity by wage share and age respectively.

Based on the differences reported in Table 2 between the increases in average tax rates based on Proposition 30 alone versus based on Proposition 30 plus federal variation relative to other states, we estimate that the treatment on California households' relative average tax rates would have been $23-40 \%$ higher without the federal reform. In the absence of the ATRA, and assuming taxpayers understood the actual net change in incentives due to both state and federal variation, this analysis suggests that the hazard rates of departure would have been larger.

\section{6.a. Transitory vs. Persistent High Earners}

It is well known that high incomes are strongly mean reverting, and this issue has been the subject of much research for example in the literature on the intensive margin response to taxation (see Weber 2014 for a recent discussion). Further, the tax revenue implications of transitorily highearners leaving California are less problematic than the out-migration of persistent high earners. It turns out that out-migration in response to Proposition 30 is driven by persistently high earners.

To see this, in Table 5 we replicate the baseline analysis in Table 3 , but add one extra taxpayer group: those whose taxable income places them in the Proposition 30 top bracket not only in year $t$, but also in $t-1$ and $t-2$. We restrict the sample to years 2002 and after to accommodate the definition of this group. The first two columns confirm that the out-migration effect holds when dropping the early years of the table; columns (3) and (4) show that taxpayers persistently filing in the top bracket fully subsume the out-migration effect from 2012-13. Figure 4 shows the year to year movements trends for such taxpayers in isolation (Appendix Figure A6 shows this series along with other income bins). Notably, this series is far more stable than the relatively noisy top-earner migration rates shown in Figure 3, suggesting that noisy year to year migration rates are due to the behavior of transitory high earners.

\section{6.b. Mover Origins and Destinations}

Figure 5 disaggregates the out-migration effect across the six largest MSAs in California by total taxable income. California resident locations in year $t$ are measured as of year $t-1$, as if year $t$ is a taxpayer's last year filing as a resident, by the time of filing taxes the taxpayer is often already

located in a different state. The figure shows that the out migration effect appears to be primarily driven by the Los Angeles - Long Beach and San Diego metropolitan areas. Appendix Table A6 shows accompanying regression estimates confirming this graphical intuition.

Figure 6 disaggregates the out-migration effect across mover destinations, by state of residence as measured in the year $t+1$ for taxpayers filing in year $t$ as California residents and moving immediately thereafter. The figure shows that the out migration effect is strongest in the direction 
of states with zero state taxes. This is consistent with the strong salience of tax considerations in relocation decisions. Appendix Table A7 contains the accompanying regression estimates, which show that $\frac{2}{3}$ of the out-migration in the $\$ 2-5$ income range is directed toward states with zero state

income tax, and $\frac{5}{7}$ of the effect is directed toward such states amongst those earning more than 5 million in taxable income. Appendix Figure A7 shows in a map the destination states of households that move out of California, both prior to Proposition 30 in 2000-09 and from 2012-13.

\section{6.c. In-Migration}

Appendix Figure A8 shows the in-migration share of the specific income brackets from $9.3 \%$ to $11.3 \%$ and then for the three sub-brackets of the $12.3 \%$ bracket. Overall, the higher the income bracket the smaller the share of a given tax bracket category that is accounted for by inward migration. We do not observe any strong effects of tax policy on the differential trends of inward migration across tax brackets.

\section{6.d. Elasticity Calculations}

As highlighted by Kleven et al. (2019), the elasticity of mobility with respect to tax policy may vary substantially depending on the specific context. However, for completeness we present here a calculation of the elasticity of out-migration to zero-tax states with respect to the difference in average tax rates between such states and California.

Focusing only on moves to zero-tax states, Appendix Table A7 shows that the treatment effects are $0.4 \%$ for the $2-5$ million bin, and $0.5 \%$ for the $5+$ million bin. Appendix Table A 8 reports that the baseline rates of migration from California to these zero-tax states are $0.394 \%$ and $0.428 \%$, respectively. These figures supply the necessary ingredients for the numerator of the elasticity. To evaluate the denominator, the disparity in average tax rate from California to the zero tax states was $6.56 \%$ in 2011 and $8.22 \%$ in 2013 for taxpayers earning $\$ 2-\$ 5$ million in 2012 , and similarly $6.78 \%$ in 2011 and $8.65 \%$ in 2013 for those earning over $\$ 5$ Million (see Section 5.a.3 for a discussion of how these figures are computed).

For taxpayers earning $\$ 2-5$ million, the elasticity is

$$
\frac{\frac{0.4}{0.394}}{\frac{8.22}{6.56}-1}=4.01
$$

For taxpayers earning over $\$ 5$ million, the elasticity is

$$
\frac{\frac{0.5}{0.428}}{\frac{8.22}{6.56}-1}=4.61
$$

Log of Net of Tax Rate. Using the log specification of Moretti and Wilson (2017) along with the log net of tax rate differences computed in Appendix Table A3, we compute the elasticity of 
migration with respect to the log net of tax rate as for the $\$ 2-\$ 5$ million bracket:

$$
\frac{\log \left(\frac{0.004+0.00394}{1-(0.004+0.00394)}\right)-\log \left(\frac{0.00394}{1-0.00394}\right)}{0.0450}=15.66
$$

where 0.0450 is the increase in the average tax rate difference between California and the zero tax states for those earning $\$ 2-\$ 5$ million. For the $\$ 5+$ million category:

$$
\frac{\log \left(\frac{0.005+0.00428}{1-(0.005+0.00428)}\right)-\log \left(\frac{0.00428}{1-0.00428}\right)}{0.0504}=15.45
$$

where 0.0504 is the increase in the average tax rate difference between California and the zero tax states for those earning $\$ 2-\$ 5$ million.

These magnitudes are far higher than those documented in Moretti and Wilson (2017), which are around 2. However, we again emphasize that our elasticity calculations should be interpreted with substantial caution; they are likely to over-state magnitudes relative to other papers because the out-migration effect we find is a one-time movement; out migration in our context reverts to pre-Proposition 30 levels after 2012-13, while for example Moretti and Wilson (2017)'s analysis finds a hazard rate of migration which increases with time.

\section{Intensive Margin Response}

\section{7.a. Covariate Balance After Matching}

Table 6 shows summary statistics for covariate balance in the year 2011 across the treatment group (that is, taxpayers filing as California residents from 2009-14 who file in the top Proposition 30 bracket in 2009-11), raw control group (taxpayers filing as California non-residents from 2009-14 who would file in the top Proposition 30 bracket in 2009-11 if all of their income were California sourced), and the two matched samples (first using the full control set as matching candidates, and secondly using only control observations filing from states with similar tax rates to California). We note that the matching procedure uses only the average levels of taxable income, AGI, and capital gains across 2009-10 to estimate the propensity score, so that 2011 balance is not baked into the procedure. Matching achieves reasonable balance across the 2011 income variables, and further also in demographics.

\section{7.b. Estimates Relative to Matched Samples of Nonresidents}

Figure 7 shows annual group averages for both logs and levels of AGI and Taxable Income. The matching procedure only matches on average levels of income across 2009-2010. Therefore, neither parallel trends in 2009-2010 and nor their continuation in 2011 is an artifact of our matching procedure. Figure 8 shows differences between the California residents in this sample and the matched nonresidents. We note these differences contain no controls for taxpayer fixed effects. 
Visually, the log differences in taxable income display essentially no trend prior to the treatment year, with a sharp drop thereafter. The differences in levels of taxable income and the differences in the levels of AGI do display downward trends in the years prior to the treatment, but visually there is a sharp drop thereafter. The difference in AGI levels do not show a clear trend break, however.

Overall, these figures suggest that the parallel trends assumption with baseline matching to all states is valid for taxable income, though perhaps not for AGI when we use match candidates from all states. When we use tax-similar-state matching, however, we find minimal pre-treatment differences in trends. Figures 9 and 10 show this analysis. Specifically, Figure 9 shows annual group averages for both logs and levels of AGI and Taxable Income, in a specification where only tax-similar states are used for the matching. Once again, the matching procedure only matches on average levels of income across 2009-2010. Therefore, neither parallel trends in 2009-2010 and nor their continuation in 2011 is an artifact of our matching procedure. The general absence of deviation from parallel trends observed in 10 shows that matching on tax-similar states will largely addresses concerns about differential pre-trends.

Table 7 shows the difference-in-difference regression estimates on the all-state sample matching, corresponding to equation 2 , with the inclusion of taxpayer fixed effects. The first row of the table shows that we do not estimate statistically or economically significant placebo treatment effects in 2011, which corroborates the graphical analysis. Across specifications, we estimate economically and statistically significant treatment effects of Proposition 30 in years 2012-14. The average high earning California resident reports 0.134 log points less in taxable income in 2012 due to Proposition $30,0.174 \log$ points in 2013, and $0.282 \log$ points in 2014. In levels, we find that residents on average reported $\$ 0.522$ million less in 2012 income, $\$ 0.357$ million less in 2013 income, and $\$ 0.599$ million less in 2014 income. The appearance of an intensive margin response in 2012 is consistent with the fact that Proposition 30 was retroactive to 2012, and as discussed in Section 3 was known to have a substantial chance of passage and in general was a salient issue in policy circles during the bulk of 2012 .

Using as a baseline the 2011 average taxable income of $\$ 4.15$ million among residents, the levels magnitudes are smaller than the log estimates in each year. That is, the average percentage treatment effect is larger than the cumulative percentage response. This outcome could be generated by the presence of a few taxpayers experiencing high income growth while the majority of others see a decline, a plausible scenario given our setting in California.

Before turning to the similar-states control group, where we observed only minimal deviations from parallel trends, we conduct two further tests to address deviation from parallel trends in the all-state matched sample. First, in Appendix Table A12, we present the results of the dynamic event study specification shown in equation 3. In this specification, the omitted year is the year before the treatment, and the test for deviation from parallel trends is the extent to which the pre-period would show opposite signed and significant coefficients. While the log AGI specification shows a small and statistically significant positive coefficient in 2009, we generally do not see significant 
evidence of deviation from parallel trends in these dynamic specifications that include taxpayer fixed effects.

Second, Table 7 also shows several statistics that emerge from robustness tests for possible parallel trend violations, following Rambachan and Roth (2019). The statistic Threshold $M$ is defined as the highest value of $M$ in the procedure of Rambachan and Roth (2019) for which the entire 95\% confidence interval for the 2012 treatment lies below zero. The fact that $M>0$ in columns (1)-(3) implies robustness to any data-implied linear deviation from parallel trends implied by the Rambachan and Roth (2019) procedure, and the results are further robust even to some degree of nonlinear deviation from parallel trends. For column (4), while the specification would not be robust to deviation from parallel trends as estimated under this procedure, the $95 \%$ confidence interval for the 2012 treatment when $M=0$ (allowing for data-implied linear deviation from parallel trends) is [-0.399,0.037].

Turning to the tax-similar states matched sample, Table 8 shows the regression estimates. For taxable income, in logs the treatment effects here appears somewhat larger, while in levels the treatment effects appear smaller. For AGI, the estimates appear to be similar or slightly smaller, with the 2012 effect having lost statistical significance. To provide conservative estimates, we base our headline elasticity calculations on the taxable income levels of this tax-similar state control group.

Table 9 examines the contribution of different income components, and specifically investment income, to the main estimates. In the data, we are able to consistently observe dividends and interest for the full sample of taxpayers from 2010 through 2013. (In other years these variables are missing for at least $90 \%$ of our sample.) Thus, in this specification we restrict to years 2010-13, using the year 2010 as the only pre-period. We further restrict to regressions in levels (not $\operatorname{logs}$ ). This provides a natural setting for a decomposition, as logs do admit additive decomposition.

In columns (1) and (2) we first confirm that the results from the main estimates carry through with this altered sample; they are smaller in magnitude, but still economically and statistically significant. Furthermore, the specifications for levels of taxable income and Federal AGI are both robust to the Rambachan and Roth (2019) procedure to account for some degree of nonlinearity in parallel trends as well as any data-implied deviation from parallel trends.

We next define "Deductions" as the difference between Federal AGI and taxable income. Consistent with the first two columns, we see that around half of the effect is due to the difference between these two quantities. We note that taxable income here for non-residents is defined as taxable income of the taxpayer if they were a California resident and their full income were subject to California state taxation. That is, the difference is reflective of actual differences between AGI and taxable income holding tax rules constant, hence justifying our labeling of this quantity as deductions.

Columns (4) and (5) show that the estimated treatment effects persist when subtracting out investment income, and if anything appear larger. Columns (6) through (8) show that we are unable to conclude that Proposition 30 has statistically significant impacts on investment income. 


\section{7.c. Elasticity Calculations}

As discussed in Section 3.c. under Proposition 30 the top marginal net of tax rate for California residents is 48.83 whereas without it would be 50.64 . The log difference between these is $3.63 \%$; this quantity is the denominator in the elasticity calculation.

To compute the numerator - that is, the change in taxable income - we rely on the main estimates for the treatment effect of Proposition 30 on the level of taxable income in 2013 relative to controls in tax-similar states, found in Table 8 column 2. We choose to use the estimate in levels rather than logs because the concavity of the log function shifts the focus away from large level movements. While helpful in some circumstances, this property in our setting may not be desirable. For example, suppose that there are 100 taxpayers for whom the marginal tax rate is raised from $10.3 \%$ to $13.3 \%$ at any level of income. Of these, there are 99 taxpayers each of whom in the absence of the tax reform would earn $\$ 100$, and each of these taxpayers display earnings under the tax reform of $\$ 95$. The last taxpayer earns $\$ 1000$ and does not respond to the

treatment. The average treatment effect in $\operatorname{logs}$ is $\frac{99}{100}[\log (95)-\log (100)] \simeq-0.05$, whereas the average treatment effect in levels is $\frac{99}{100} \times-5=-4.95$. Using these treatment effect estimates, the revenue consequences using the log version would imply far more serious revenue consequences than would the levels version. This is because the log result focuses on the average percentage effect, which in this scenario is concentrated in lower-level incomes which are less relevant to revenue considerations than the behavior of the single taxpayer earning $\$ 1000$. This example is obviously highly stylized and unrealistic, but displays the intuition that levels are perhaps a more natural specification for studying the revenue consequences of taxing high-earners. Further, it turns out that in our specifications the levels estimates are more conservative than log estimates, so in a practical sense this procedure gives conservative estimates.

Using a $\$ 4.15$ million baseline value for taxable income, the 2013 treatment effect of $\$ 0.373$ million dollars for tax similar states is $8.99 \%$ of the mean value, and the 2014 treatment effect is $\$ 0.481$ of the mean value. With the denominator of $3.63 \%$, this yields a rough elasticity of income with respect to the marginal net of tax rate in the range of 2.5-3.2. This is a large estimate relative to the classic public finance literature. We emphasize that the estimate is for California residents on average earning over $\$ 4$ million dollars in taxable income annually, although also that according to the latest FTB statistics approximately $40 \%$ of the individual income tax in California is paid by those with taxable income of over $\$ 1$ million.

\section{Policy Implications}

\section{8.a. California Tax Revenue}

We use the estimates from our intensive margin estimation exercise to perform a back of the envelope calculation, aimed at quantifying the fraction of windfall revenue accruing to the state of California from the Prop 30 policy shift which was lost to behavioral responses. 
Intensive Margin. The matching and differences in differences methodology above yields yearly estimates of average treatment effects in levels among repeated top-bracket California taxpayers for each of 2012, 2013, and 2014. We re-estimate these treatment effects separately within marital status cells using a disaggregated version of our main specification, since tax bracket cutoffs vary across such cells. ${ }^{35}$ For each marital status by year cell, we define a representative taxpayer as the mean taxable income in each cell, assuming all income is in wages and no itemized deductions outside the state tax deduction. For each such earnings profile, we first compute the revenue gains to California from Proposition 30's tax increases assuming no behavioral change. We then use the econometric estimates to compute the revenue gains from Prop 30 under observed behavioral changes. Aggregating up across marital status cells using population ratios allows us to compute the percentage of windfall revenue gains dissipated by behavioral responses on the intensive margin.

Using this procedure, the levels results imply that $46.6 \%$ of windfall revenue gains are dissipated by intensive-margin behavioral response in 2012 among the group of California resident taxpayers analyzed. The intensive margin response dissipates $40.9 \%$ of such gains in 2013, and $56.7 \%$ in 2014 .

To illustrate, consider married California residents, who in every year from 2012-14 comprise approximately $67 \%$ of the sample. ${ }^{36}$ To illustrate the calculation consider the case of married California residents in 2013 (and note all calculations use 2015 dollar values). For this subset, the mean observed income is $\$ 4,459,590$. To compute the revenue gains to the state of California from Proposition 30 under this observed behavior, we calculate that this representative taxpayer pays an additional amount of

$$
(631,732-526,444) * .01+(1,052,886-631,732) * .02=\$ 9,476
$$

over the $10.3 \%$ and $11.3 \%$ brackets. The taxpayer then has $\$ 3,406,704$ of income in the top bracket, on which California earns an additional $3 \%$, leading to a revenue gain of $\$ 102,201$. In total, the revenue gain the state has over and above what it would have had under the old tax code at the same level of income is therefore $\$ 102,210+\$ 9,476=\$ 111,677$.

For these calculations, we estimate treatment effects specific to marital filing status. The married-specific treatment effect estimate is $\$ 298,000$ as shown in Table A10. Since in this example we are considering the case of reported 2013 income, the income is already net of this behavioral response. Continuing to use the married-specific treatment for the sake of example, while the state has gained $\$ 111,677$ relative to what it would have received at the same income level under the old tax code, it has also lost $\$ 298,000 \times .103$ due to behavioral responses or $\$ 30,964$, as in the absence of the tax this amount would have been earned and taxed at the pre-reform top rate of $10.3 \%$. This leads to revenue gain of $\$ 111,677-\$ 30,694=\$ 80,983$, net of the behavioral response.

Now suppose there were no behavioral response. The additional revenue from inframarginal tax brackets does not change. However, the taxpayer has $\$ 3,406,704+\$ 298,000$ of income in the top bracket, on which California earns an additional $3 \%$, leading to a revenue gain of $\$ 120,617$.

\footnotetext{
${ }^{35}$ Appendix Tables A9 A10 and A11 contain the marital status specific estimates used for this procedure.

${ }^{36}$ Single filers account for $29 \%$, and head of household filers make up the remaining $4 \%$.
} 
This implies that among married couples, the intensive margin behavioral response dissipates 1 $\frac{\$ 80,983}{\$ 120,617}=0.328$ of windfall revenue gains from taxation. This is aggregated with single and head of household figures through a weighted average (using the weights $0.67,0.29$, and 0.04) leading to the aggregate figure $40.9 \%$ (the treatment effect point estimates in 2013 are larger for singles and heads of household, see Appendix Tables A9 and A11.

Extensive Margin. To understand the impact together of the extensive and intensive margin estimates, we rely on the estimates in Table 5 which demonstrate that the out-migration effect is concentrated among taxpayers who have filed in the top California bracket three years in a row. In this manner we aim to arrive at an estimate which will inform the revenue implications of our behavioral estimates with regard to this particular class of high-earning taxpayers.

To incorporate this margin, we use the estimate that there was 0.9 percentage point increase in the hazard rate of out-migration for taxpayers who had filed in the top California bracket three years in a row. Assuming that the representative taxpayer in this group earned $\$ 4.15$ million, ${ }^{37}$ they were paying $\$ 515,135$ in taxes to California. ${ }^{38}$ Including this additional margin, the state loses $45.2 \%$ of its windfall gains in 2013, so that the extensive margin accounts for $9.5 \%$ of the behavioral response impact on tax revenues in the year 2013. A similar calculation for 2014 yields an effect of $60.9 \%$.

State Tax Deductibility and Revenue Impact Magnitudes. We note that in light of the very large intensive margin elasticity estimate, the revenue impact calculated above may seem smaller than reasonably expected. This is an artifact of the deductibility of state and local taxes during our sample period: whereas California raised top rates by $3 \%$ and state tax revenues reflect this fully, the state tax increase implicitly lowers the federal tax increase so that the effective top rate increases less than $3 \%$. In particular, with a $39.6 \%$ top rate, a $3 \%$ state tax increase is accompanied by a $39.6 \% \times .03=1.188 \%$ drop in the federal tax rate, so that the effective top rate increase is $1.812 \%$.

\section{8.b. 2018 Federal Tax Reform}

In 2018, Congress passed the "Tax Cuts and Jobs Act" (TCJA). Under this law, the top rate is $37 \%$ for single and head-of-household filers earning over $\$ 500,000$, and for married filers earning over $\$ 600,000$. Despite this nominal cut to top rates, the legislation on net increased rates on top earners because it capped state and local deductions at $\$ 10,000$ total. $^{39}$

Intensive Margin. First we use our top line intensive margin elasticity estimate to provide a ballpark quantification of the federal tax revenue implications of TCJA for the particular set of California high earners in our treatment group. As we showed in 3.c, incorporating the SALT

\footnotetext{
${ }^{37}$ This uses the average taxable income for 2011, which is more conservative than using the average from 2012 which is distorted by income shifting from 2013

${ }^{38}$ This quantity is computed using TAXSIM assuming a married taxpayer earning all wage income, and that $83.6 \%$ of the taxable base moves out of California, which is conservative as some high earners do fully migrate out.

${ }^{39}$ The "Pease provision" was repealed by TCJA until 2025 under this legislation. The Pease Provision had reduced the marginal rate gains to itemized deductions by $3 \%$.
} 
deduction and the Pease Provision, the net-of-tax rate for a California high earner in 2017 in the $13.3 \%$ bracket was $100-\left(39.6^{*}(1-0.133+0.03)+13.3+2.35\right)=48.83$. In 2018 , with the capping of the SALT deduction, the net-of-tax rate for the same high earner is simply $100-(37+13.3$ $+2.35)=47.35$. Using the elasticity estimate of 2.8 , we compute that top-earner incomes for the particular group of high-income California residents in our sample would change by $2.8 \times$ $(\log (47.35)-\log (48.83))=-0.086 \log$ points.

Consider a married California taxpayer earning $\$ 4.15$ million of wage income. In 2017 , this taxpayer pays a federal tax bill of $\$ 1,431,305$. In 2018 , incorporating the $8.6 \%$ income decrease, this taxpayer pays a federal tax bill of $\$ 1,333,946$. This amounts to a $6.8 \%$ decrease in tax revenue, putting the TCJA on the wrong side of the Laffer Curve for high-earning individuals in California. This calculation should be interpreted with caution, since our estimates are interpreted as an average treatment effect specific to our particular group of California high-earners (that is, those filing in the top California tax bracket three years in a row). Further, the literature such as Gruber and Saez (2002) has found that taxpayer intensive margin decisions are more sensitive to state than to federal tax policy changes.

Extensive Margin. The TCJA led to changes in average tax rate differences between states as a result of the SALT deduction cap. In Appendix Figure A13, we repeat the computations from Table 2 to assess how the $2018 \mathrm{CA}$-other state gap in average taxes paid grew over and above the 2017 CA-other state gap. The gap is reported only for the case of zero income tax states. The zero-tax states in this period are the same as in the prior exercise, with the exception of Wyoming which changed policy between 2017-18. ${ }^{40}$ Taxpayer behavior is still fixed at year 2012 levels suitably inflation-indexed. While we would ideally use year 2017 data, we do not have access to these data. We simply carry through 2012 behavior for parsimony and ease of comparison with our other calculations.

Comparing Table 2 to Table A13 reveals that the TCJA increased incentives (in terms of the level of the average tax rate gap) to leave California for zero-tax states by 2.15 times the amount of Proposition 30 for those earning over $\$ 5$ million, and by a factor of 2.43 for those earning from $\$ 2-5$ million. Based on these scaling factors, we would predict an out-migration effect of $1.46 \%$ of those earning $\$ 2-5$ million, and $1.51 \%$ of those earning $\$ 5$ million.

\section{Conclusion}

The issue of behavioral responses to income taxation is an important question in academic and policy circles. Prior research has made important progress in this area, but substantial controversy remains. In this paper we draw on rich microdata on the universe of tax returns from the California FTB to provide two new data points to inform this debate with a particular focus on the income taxation of high earners.

First, we document a substantial one-time out-migration response to increased state tax rates.

\footnotetext{
${ }^{40}$ This group is as follows: Alaska, Florida, Nevada, Texas, South Dakota, and Washington.
} 
Relative to the pre-period 2000-10, the taxable income weighted rate of departures amongst topbracket taxpayers was abnormally high by $0.8 \%$ in $2012-13$. Consistent with the theoretical prediction that migration decisions respond to average tax rates, this migration effect increases with income and is concentrated among taxpayers earning over $\$ 2$ million dollars.

Second, we provide a simple, transparent framework to study the intensive margin response to Proposition 30's increased marginal tax rates for taxpayers who do not respond on the extensive margin. We use a differences-in-differences design which compares upper-income California resident taxpayers to a matched sample of non-resident California filers who are not subject to Proposition 30 's higher tax rates (except through the small share of their income filed in California). Our design focuses on California taxpayers who are likely to earn top-bracket incomes in the absence of Proposition 30, defined as those who file in the new Proposition 30 top-bracket in each of the years 2009, 2010, and 2011. To increase covariate balance between the treatment and control groups, we apply a propensity score matching method which matches only on 2009-10 covariates. This procedure leaves the equality of covariate values in 2011 as a testable implication of the unconfoundedness assumption, which we cannot reject. This increases our confidence in the empirical design.

Our intensive margin estimates show a substantial intensive margin response to Proposition 30, which appears in 2012 and persists through the last year of our analysis in 2014. We find that this intensive margin response is concentrated in non-investment income. Using the more conservative levels result from 2013 compared to the similar-states sample, the estimates imply an elasticity of taxable income with respect to the marginal net of tax rate of 2.5 to 3.2 .

Overall, we find strong behavioral responses to income taxation amongst high earners. Despite this, we are unable to provide convincing evidence as to the normative implications of the results. On the one hand, decreased high-earner income in response to taxation could reflect the distortion of productive activity among those residents whom California's most innovative residents. This could encompass the classic labor supply channel or other channels such as idea generation and innovation, as in Jones (2019). On the other hand, our results may also be driven by higher taxes reducing the incentive to engage in wasteful rent-seeking activities, such as wage negotiations by CEOs (as in Piketty, Saez and Stantcheva 2014). While we are able to perform simple calculations to inform the revenue consequences of our estimates, the broad policy and welfare implications of our work depend on these unanswered questions. We view this as an important avenue for future research. 


\section{References}

Agrawal, David and Dirk Foremny. 2019. "Relocation of the Rich: Migration in Response to Top Tax Rate Changes from Spanish Reforms." Review of Economics and Statistics 101(2):214-232.

Akcigit, Ufuk, Salome Baslandze and Stefanie Stantcheva. 2016. "Taxation and the International Mobility of Inventors." American Economic Review 106(10):2390-2981.

Ballotpedia. 2012. "California Proposition 30, Sales and Income Tax Increase (2012).”.

Borusyak, Kirill and Xavier Jaravel. 2016. "Revisiting Event Study Designs." Working Paper .

Chetty, Raj. 2009. "Is the taxable income elasticity sufficient to calculate deadweight loss? The implications of evasion and avoidance." American Economic Journal: Economic Policy 1(2):3152.

Coomes, Paul A. and William H. Hoyt. 2008. "Income Taxes and the Destination of Movers to Multistate MSAs." Journal of Urban Economics 63(3):920-937.

de Chaisemartin, Clément and Xavier D’Haultfouille. 2018. "Two-way Fixed Effects Estimators with Heterogeneous Treatment Effects." Working Paper.

Devereux, Michael P. and Rachel Griffith. 1998. "Taxes and the Location of Production: Evidence from a Panel of Multinationals." Journal of Public Economics 68(3):335-367.

Diamond, Peter and Emmanuel Saez. 2011. "The Case for a Progressive Tax: From Basic Research to Policy Recommendations." Journal of Economic Perspectives 25(4):165-190.

Feenberg, D. and E. Coutts. 1993. "An introduction to the TAXSIM model." Journal of Policy Analysis and Management 12(1):189-194.

Feldstein, Martin. 1995. "The effect of marginal tax rates on taxable income: a panel study of the 1986 Tax Reform Act." Journal of Political Economy 103(3):551-572.

Feldstein, Martin. 1999. "Tax avoidance and the deadweight loss of the income tax." Review of Economics and Statistics 81(4):674-680.

Feldstein, Martin and Marian Vaillant Wrobel. 1998. "Can state taxes redistribute income?" Journal of Public Economics 68(3):369-396.

Gale, William G. and Orszag Peter. 2004. "Bush Administration Tax Policy: Introduction and Background." Tax Notes 104(12):1291-1300.

Giertz, Seth H. 2007. "The Elasticity of Taxable Income Over the 1980s and 1990s." National Tax Journal 60(4):743-768. 
Gruber, Jonathan and Emmanuel Saez. 2002. "The elasticity of taxable income: evidence and implications." Journal of Public Economics 84:1-32.

Imbens, Guido and Jeffrey Wooldridge. 2009. "Recent Developments in the Econometrics of Program Evaluation." Journal of Economic Literature 46(1):5-86.

Jones, Charles I. 2019. "Taxing Top Incomes in a World of Ideas.” Working paper .

Kawano, Laura, Caroline Weber and Andrew Whitten. 2016. "Estimating the Elasticity of Broad Income for High-Income Taxpayers." Working Paper .

Kleven, Henrik Jacobson, Camille Landais and Emmanuel Saez. 2013. "Taxation and international migration of superstars: Evidence from the European football market." American Economic Review 103(5):1892-1924.

Kleven, Henrik Jacobson, Camille Landais, Emmanuel Saez and Esben Anton Schultz. 2014. "Migration and Wage Effects of Taxing Top Earners: Evidence from the Foreigners' Tax Scheme in Denmark." Quarterly Journal of Economics 129(1):333-378.

Kleven, Henrik Jacobson and Esben Anton Schultz. 2014. "Estimating Taxable Income Responses Using Danish Tax Reforms." American Economic Journal 6(4):271-301.

Kleven, Henrk, Camille Landais, Mathilde Munoz and Stefanie Stantcheva. 2019. "Taxation and Migration: Evidence and Policy Implications." Working Paper .

Leigh, Andrew. 2008. "Do Redistributive State Taxes Reduce Inequality?" National Tax Journal 61(1):81-104.

Moretti, Enrico and Daniel Wilson. 2017. "The Effect of State Taxes on the Geographical Location of Top Earners: Evidence from Star Scientists." American Economic Review 107(7):1858-1903.

Novak, Viveca. 2013. "Americans for Responsible Leadership Wholly Funded by Koch-Linked Group." Open Secrets.org .

Nunnes, James and Jeffrey Rohaly. 2013. "Economic Growth and Tax Relief Reconciliation Act of 2001." Tax Policy Center pp. 1-8.

Piketty, Thomas, Emmanuel Saez and Stefanie Stantcheva. 2014. "Optimal Taxation of Top Labor Incomes: A Tale of Three Elasticities." American Economic Journal 6(1):230-271.

Rambachan, Ashesh and Jonathan Roth. 2019. "An Honest Approach to Parallel Trends." Working Paper.

Richardson, Hope. 2012. "What Would Proposition 30 Mean for California?" California Budget Project pp. 1-12. 
Saez, Emmanuel. 2001. "Using Elasticities to Derive Optimal Income Tax Rates." The Review of Economic Studies 68(1):205-229.

Saez, Emmanuel. 2017. "Taxing the Rich More: Preliminary Evidence from the 2013 Tax Increase." Tax Policy and the Economy 31:71-120.

Saez, Emmanuel, Joel Slemrod and Seth Giertz. 2012. "The Elasticity of Taxable Income with Respect to Marginal Tax Rates: A Critical Review." Journal of Economic Literature 50(1):3-50.

Slemrod, Joel and Shlomo Yitzhaki. 2002. Tax avoidance, evasion, and administration. In Handbook of Public Economics. Vol. 3 Elsevier pp. 1423-1470.

Varner, Charles, Cristobal Young and Allen Prohofsky. 2018. "Millionaire Migration in California: Administrative Data for Three Waves of Tax Reform." Working Paper.

Weber, Caroline. 2014. "Toward Obtaining a Consistent Estimate of the Elasticity of Taxable Income Using Difference-in- Differences." Journal of Public Economics 117:90-103.

Young, Cristobal and Charles Varner. 2011. "Millionaire Migration and State Taxation of Top Incomes: Evidence from a Natural Experiment." National Tax Journal 64(2):255-284.

Young, Cristobal, Charles Varner, Ithai Z. Lurie and Richard Prisinzano. 2016. "Millionaire Migration and Taxation of the Elite: Evidence from Administrative Data." American Sociological Review 81(3):421-446.

Zucman, Gabriel. 2014. "Taxing across Borders: Tracking Personal Wealth and Corporate Profits." American Economic Journal 28(4):121-148. 


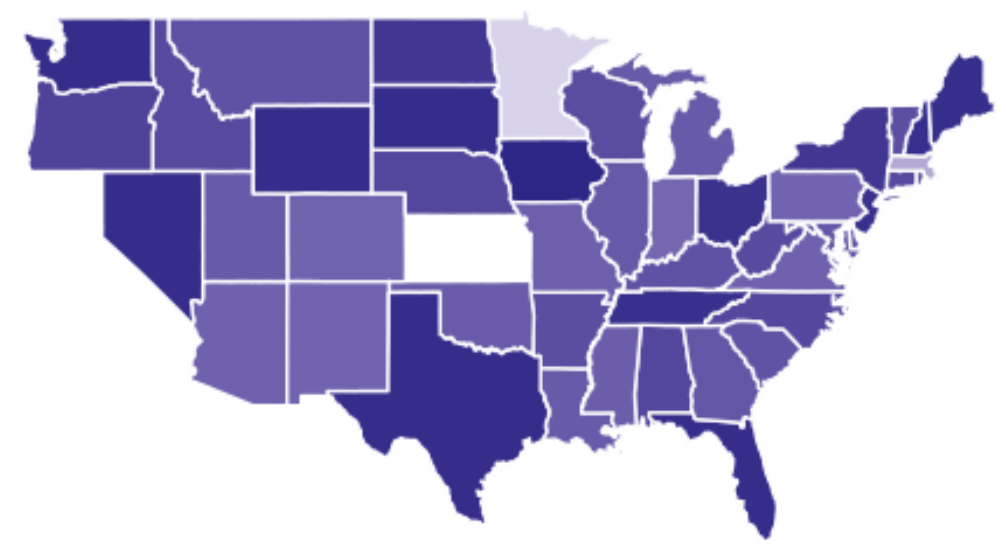

'Percentage Points Increase' 1.6

1.2

0.8

0.4

Figure 1: 2012-13 California Average Rate Increases Relative to Other States, $\$ 5+$ Million Earners

See Section 5. a.3 for a full discussion of this figure. This map shows the Proposition 30-driven incremental savings in average taxes paid from moving out of California from years 2012-13. Note: Kansas is omitted as it dropped rates substantially from 2012-13, leading to large value (around 3) which would obscure the variation in other values. 


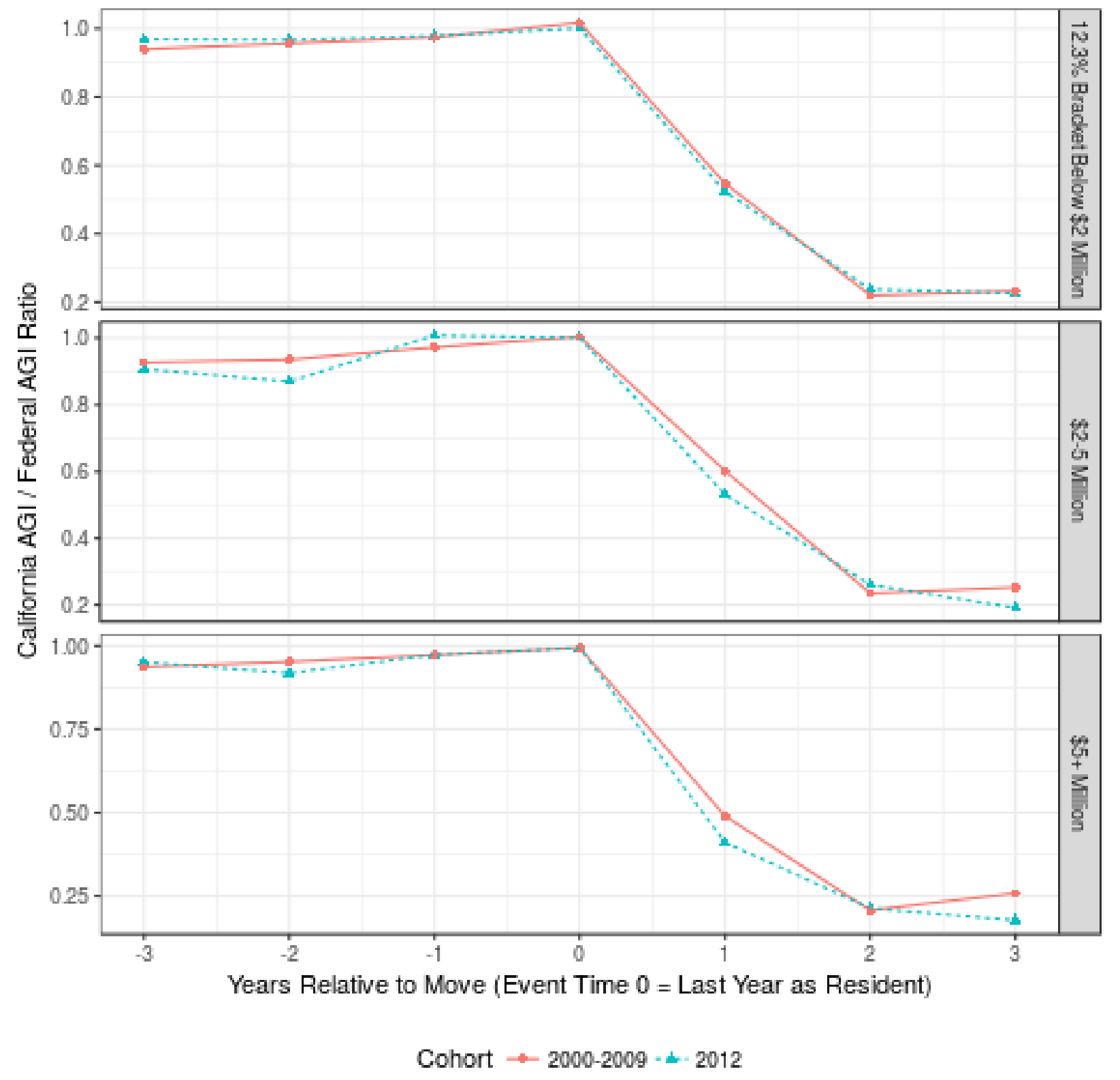

Figure 2: How Much Income Leaves California with Non-Resident Out-Migrants?

The sample is all taxpayers who displayed a Resident - Non resident - Non resident transition, where in the "Resident" year the taxpayer was in the top tax bracket according to 2012 tax policy. 


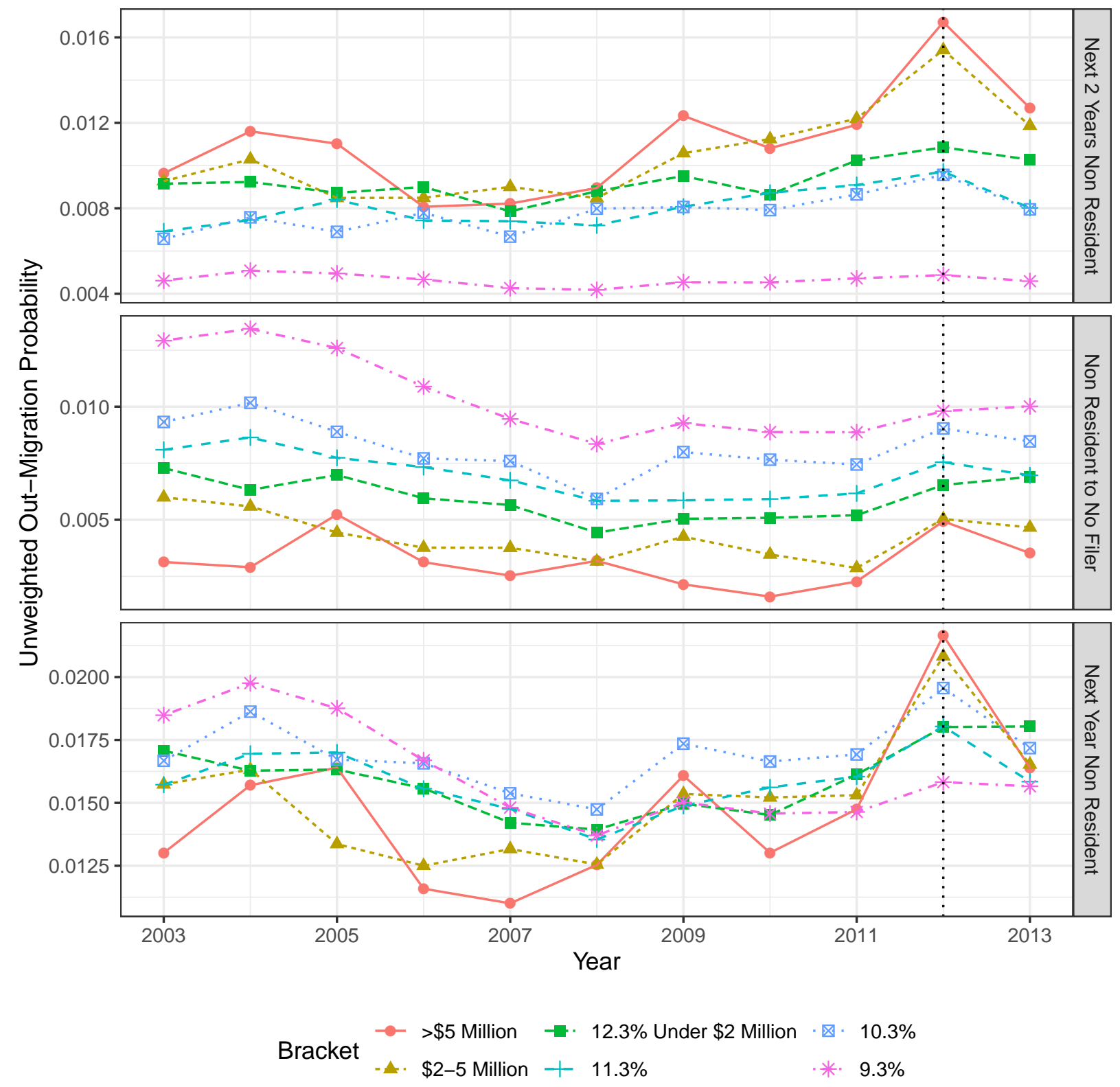

Figure 3: Out-Migration Probabilities

This figure shows the rate of out-migration among current-year residents, disaggregated by taxable income bins. 


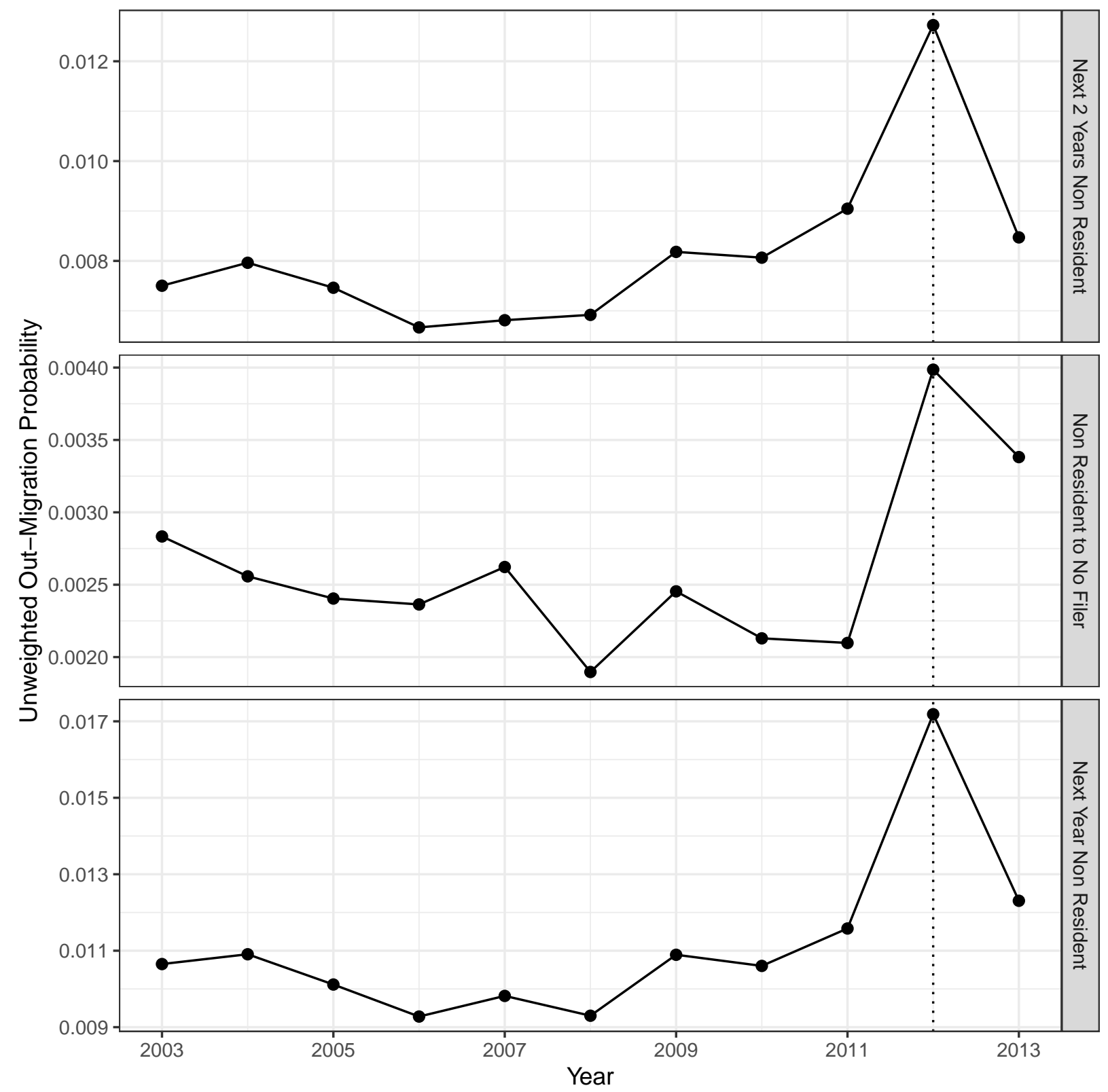

Figure 4: Out-Migration Probabilities - Three-Year Top Bracket Only

This figure shows the rate of out-migration among current-year residents who are in the top bracket in not only the current year but also the past two years. 


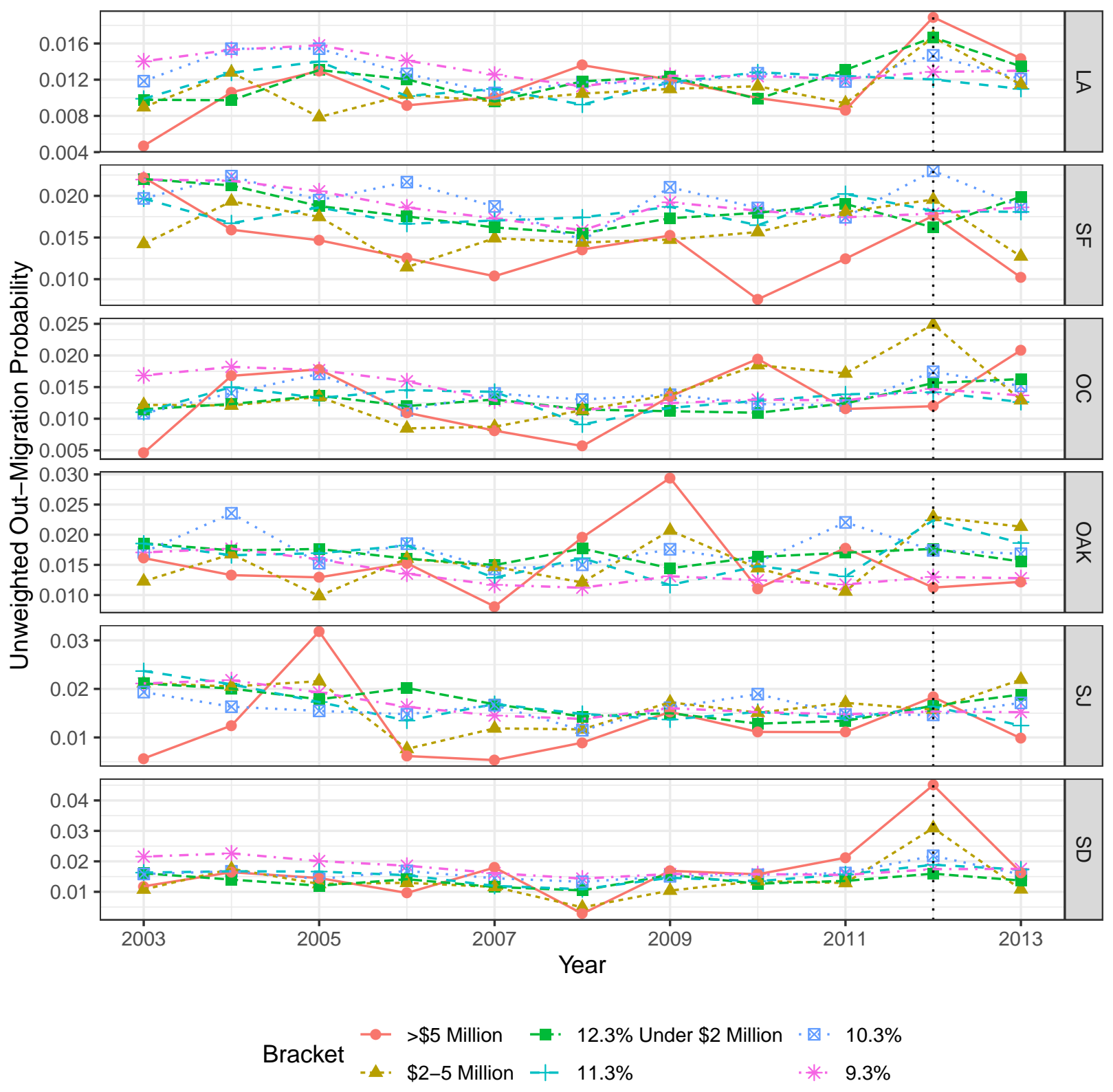

Figure 5: Out Migration by MSA

This figure decomposes out-migration across the 6 largest MSAs in California, by total tax base as of 2010; these MSAs account for 73.5\% of Taxable Income in 2010. LA is Los Angeles-Long Beach (Los Angeles County), SF is San Francisco (Marin County, San Francisco County, and San Mateo County), OC is Orange County (Orange County), OAK is Oakland (Alameda County and Contra Costa County), SJ is San Jose (Santa Clara County), SD is San Diego (San Diego County). MSA classifications are based on a 2005 crosswalk accessible through the NBER website ${ }^{41}$.

${ }^{41}$ https://www.nber.org/data/cbsa-msa-fips-ssa-county-crosswalk.html 


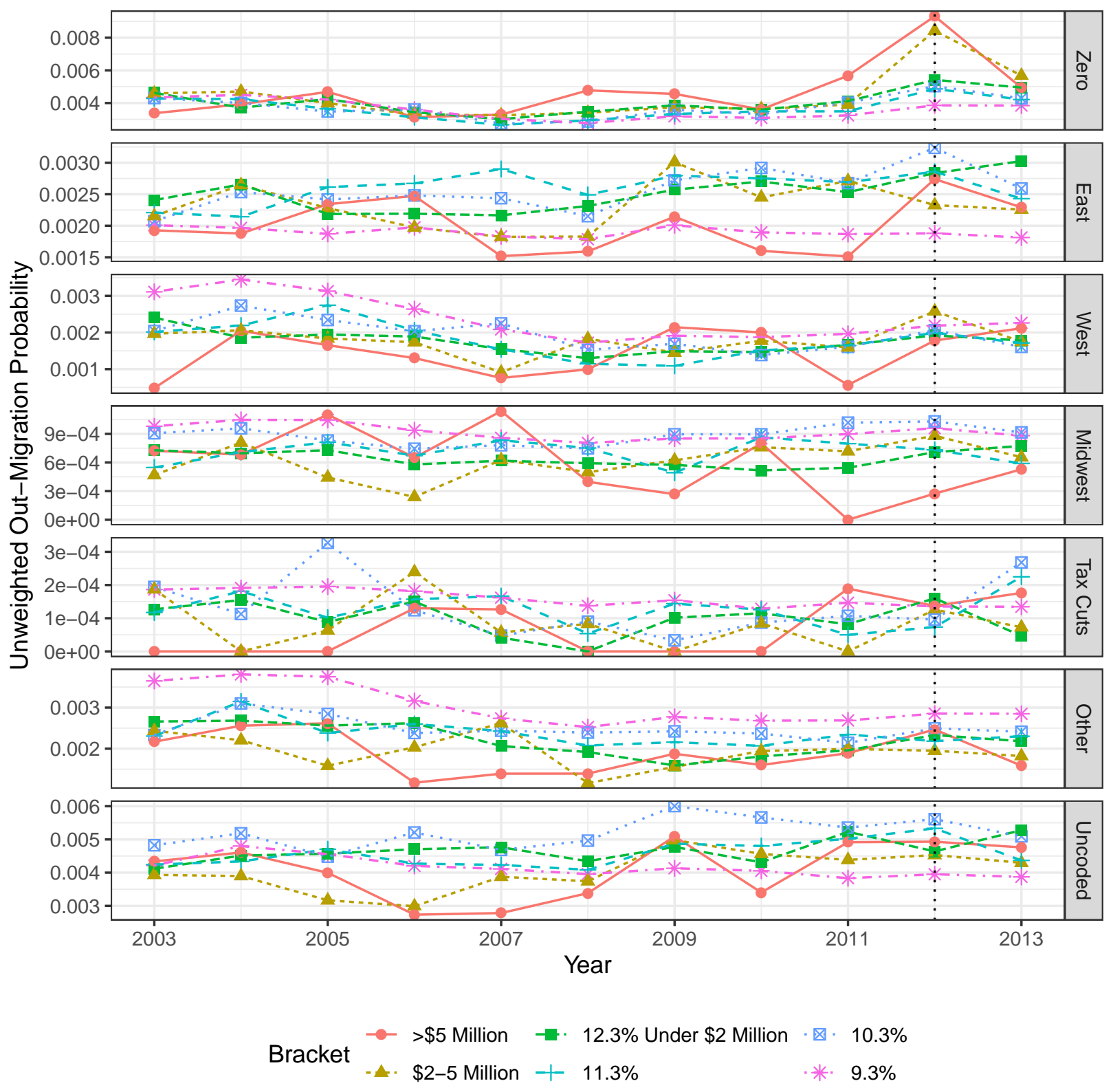

Figure 6: Out Migration Destinations

Mover destinations are measured as of year $t+1$ for a move beginning in year $t$ for a year $t$ California resident. "Zero" denotes states with a zero state tax, which is Wyoming, Washington, Texas, South Dakota, Nevada, Florida, and Alaska. "East" denotes New York, New Jersey, Massachusetts, Pennsylvania, District of Columbia, and Connecticut. "Midwest" denotes Illinois, Ohio, Michigan, and Wisconsin. "West" denotes Oregon, Colorado, Arizona, and Utah. "Tax Cuts" denotes Iowa, Kansas, and Maine. "Other" is all other states, and "Uncoded" are observations for which the forward location code is not populated or does not map to a state. 
Figure 7: Matched Sample Income Trends
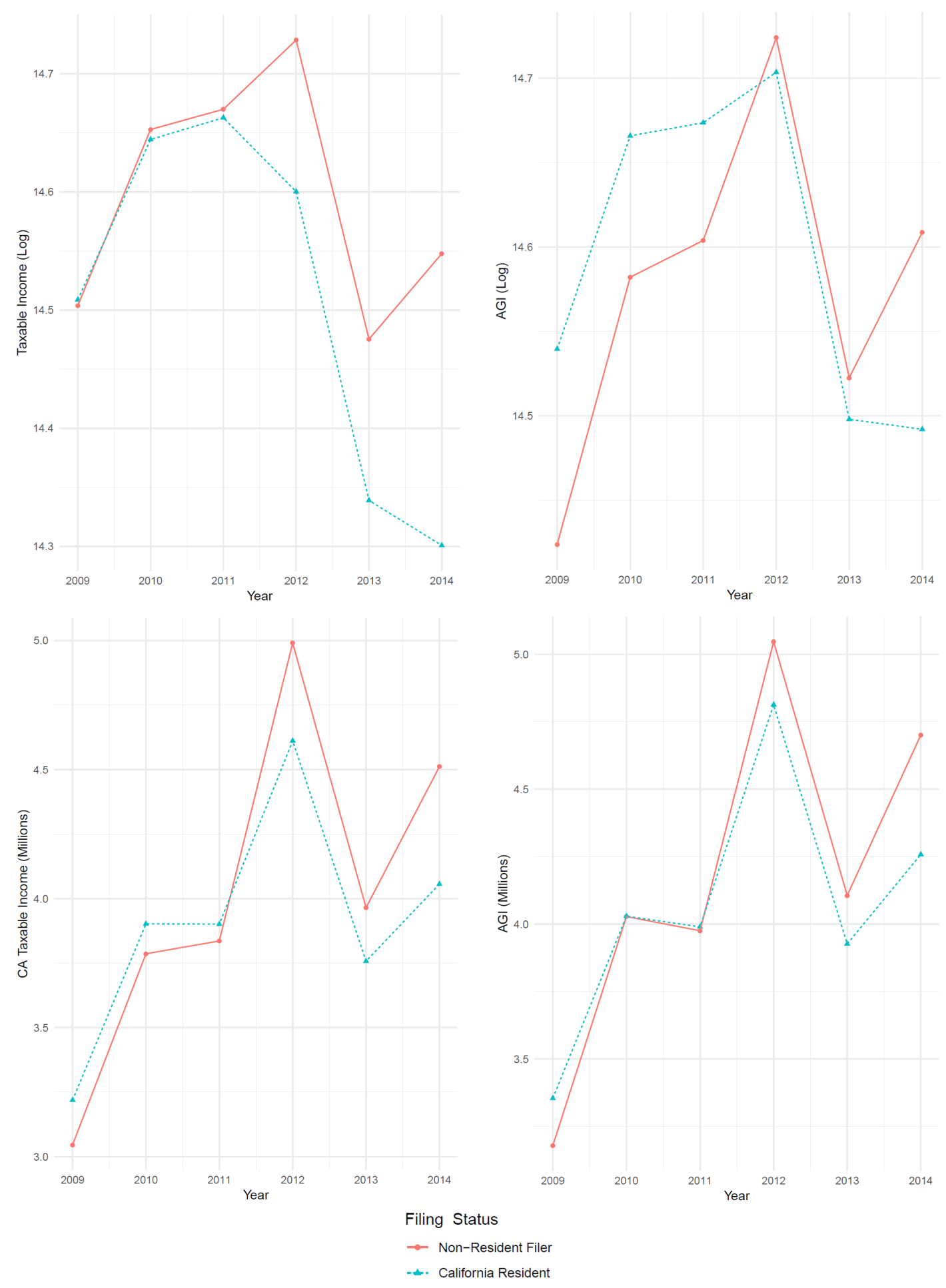

This figure shows annual group averages for both logs and levels of AGI and Taxable Income. The matching procedure only matches on average levels of income across 2009-2010. Therefore, neither parallel trends in 2009-2010 and nor their continuation in 2011 is an artifact of our matching procedure. 
Figure 8: Income Trend Differences between California Residents and Matched Non-Resident Filers
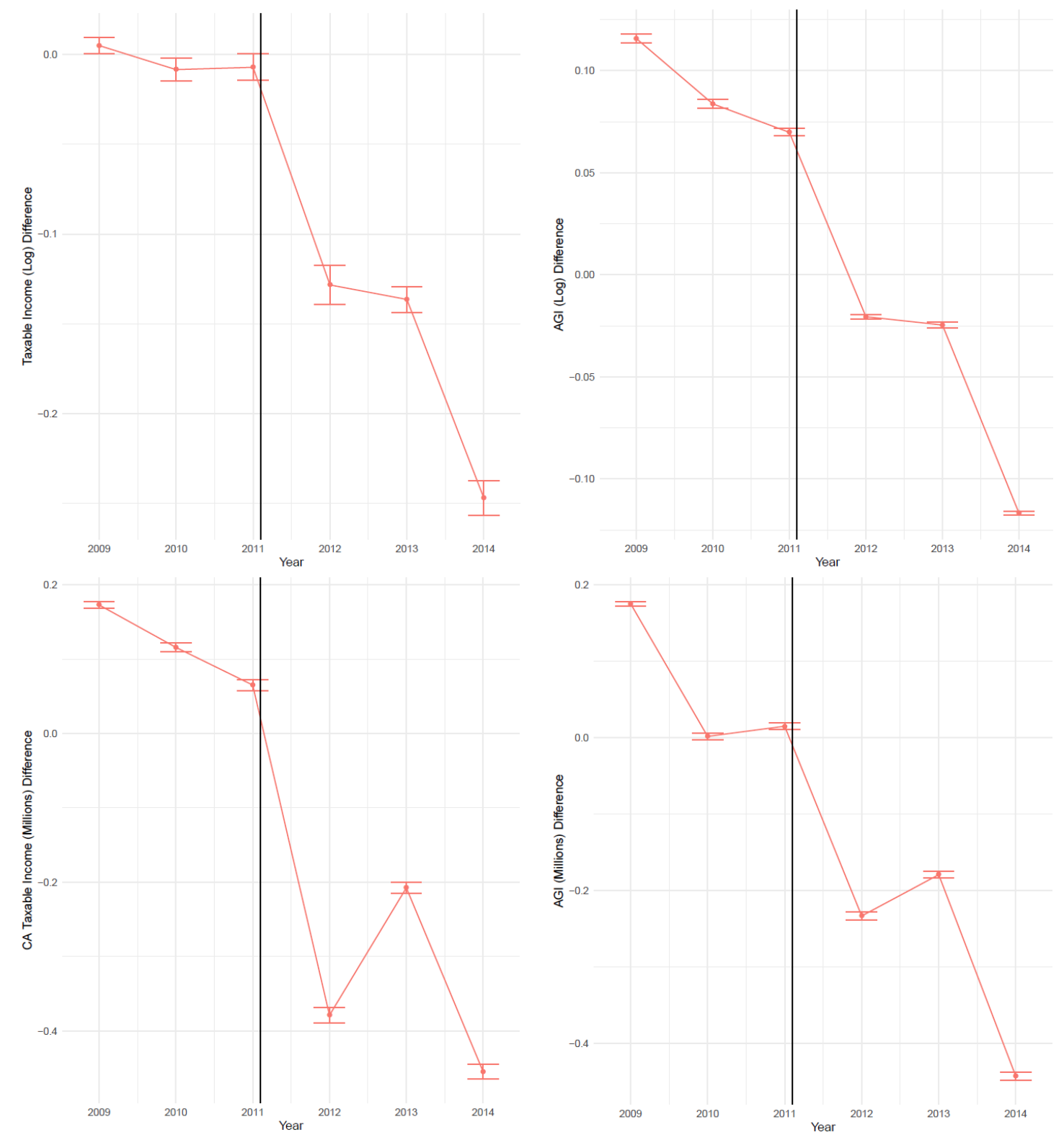

This figure shows income differences between California resident and matched non-resident filer annual group averages, with error bands showing plus and minus two standard errors of the mean. The matching procedure only matches on average levels of income across 2009-2010. Therefore, neither parallel trends in 2009-2010 and nor their continuation in 2011 is an artifact of our matching procedure. 
Figure 9: Matched Sample Income Trends: Similar-Tax States Control Group Restriction
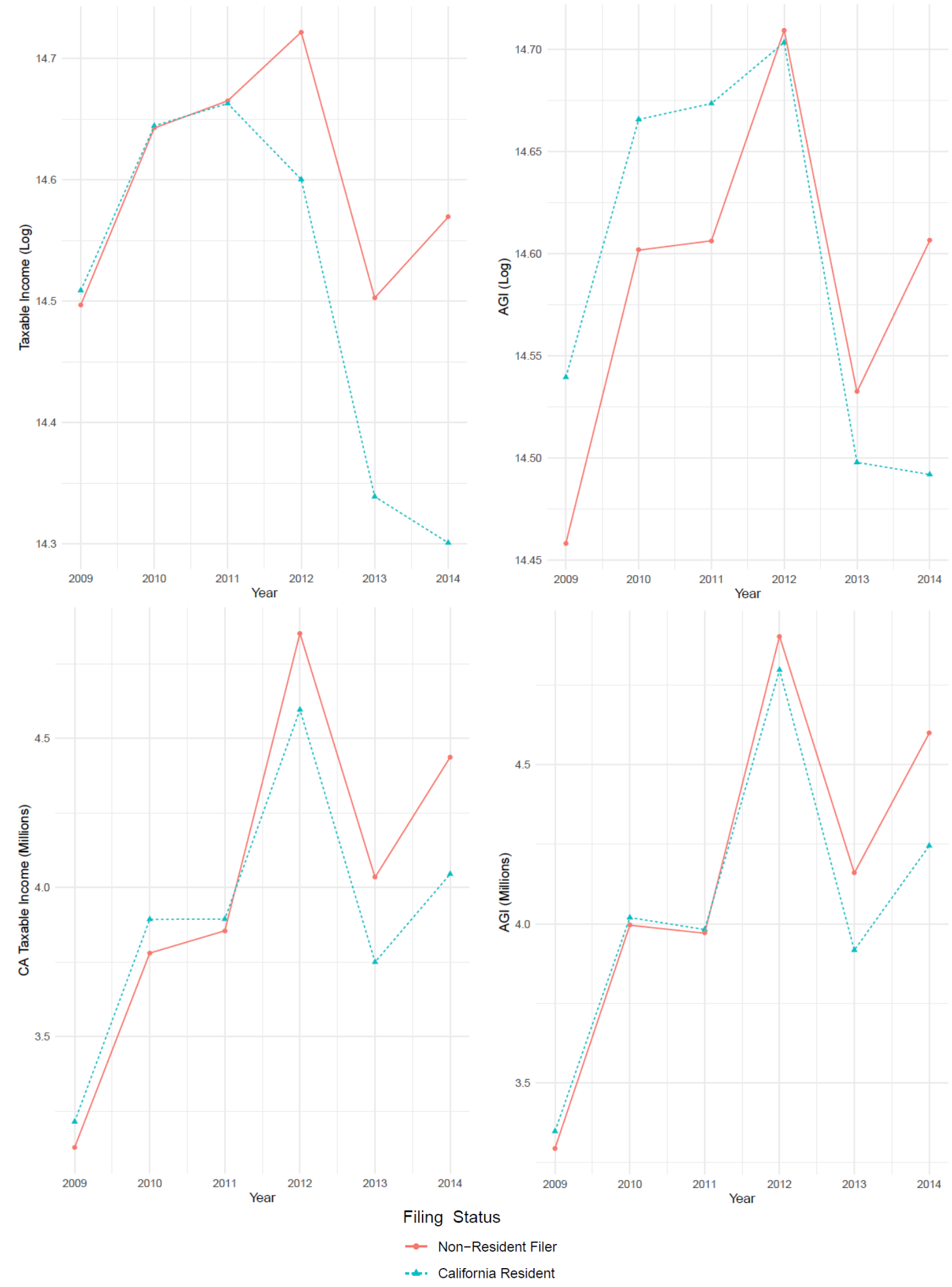

This figure shows annual group averages for both logs and levels of AGI and Taxable Income, when only tax-similar states are used for the matching. The matching procedure only matches on average levels of income across 2009-2010. Therefore, neither parallel trends in 2009-2010 and nor their continuation in 2011 is an artifact of our matching procedure. 
Figure 10: Income Trend Differences between California Resident and Non-Resident Filers
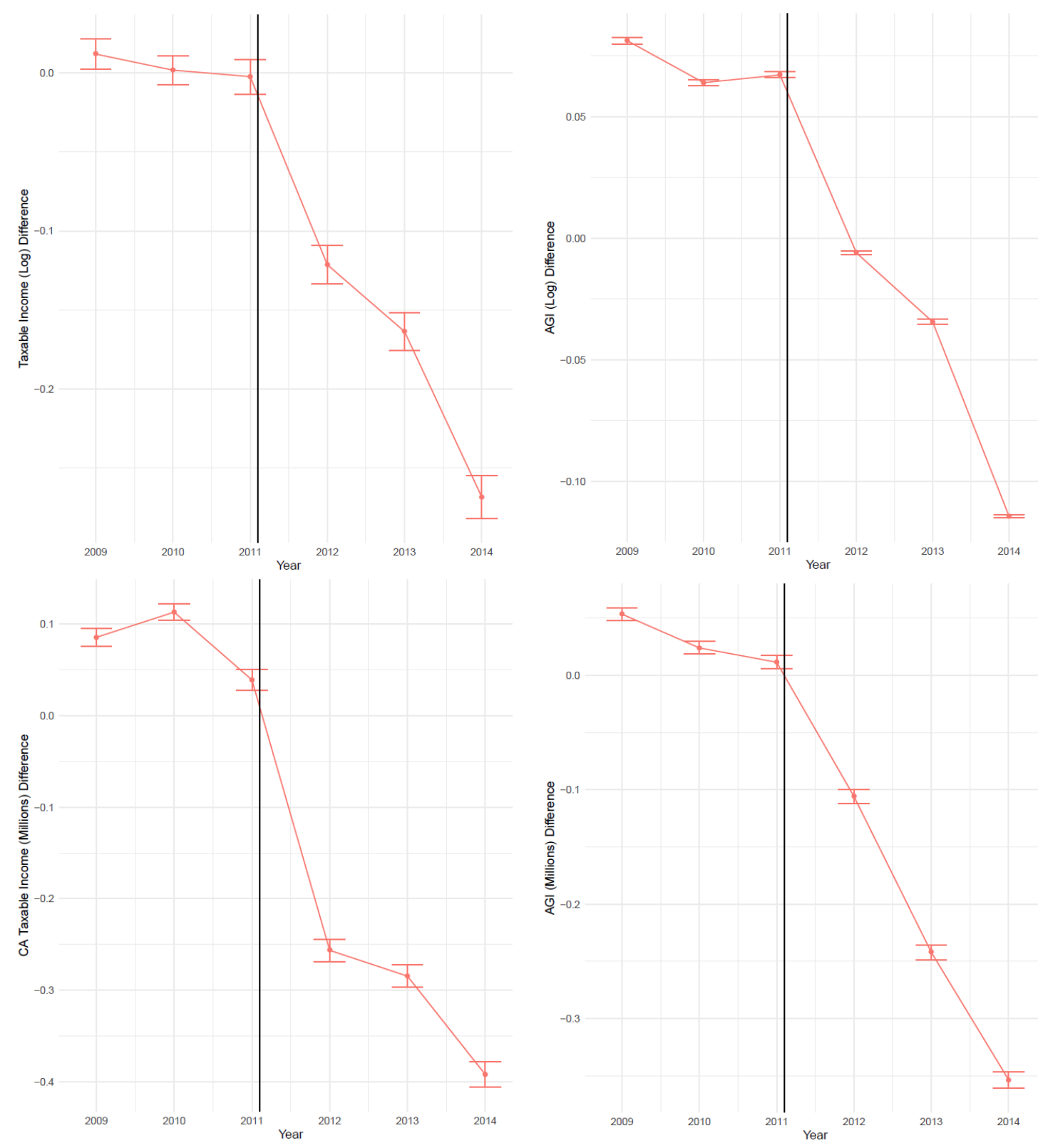

This figure shows annual average income differences between California resident and matched non-resident filers from similar-tax states, with error bands showing plus and minus two standard errors of the mean. The matching procedure only matches on average levels of income across 2009-2010. Therefore, neither parallel trends in 2009-2010 and nor their continuation in 2011 is an artifact of our matching procedure. 
Table 1: Summary Statistics

\begin{tabular}{lccccccc}
\hline \hline & & & & & & & \\
& Mean & SD & p1 & p10 & p50 & p90 & p99 \\
\hline Wage & 50,356 & 67,127 & 0 & 0 & 29,985 & 122,424 & 345,427 \\
Federal AGI & 77,373 & 124,526 & $-4,266$ & 10,129 & 44,070 & 157,387 & 676,565 \\
California AGI & 67,692 & 95,290 & $-5,290$ & 8,212 & 40,198 & 145,393 & 520,396 \\
Taxable Income & 61,730 & 115,476 & 0 & 2,277 & 31,639 & 127,807 & 625,057 \\
Deductions & 14,237 & 16,021 & 4,042 & 4,043 & 8,087 & 32,849 & 84,777 \\
Dependents & .807 & 1.140 & 0 & 0 & 0 & 2 & 4 \\
Married & .407 & .491 & 0 & 0 & 0 & 1 & 1 \\
Non-resident & .051 & .220 & 0 & 0 & 0 & 0 & 1 \\
Cal AGI/Fed AGI Ratio & .933 & .207 & 0 & .782 & 1 & 1 & 1.19 \\
\hline$N$ & $241,490,744$ & \multicolumn{7}{c}{} & & & & & \\
\hline \hline
\end{tabular}

The table shows summary statistics for all observations pooled over the time period 2000-15. The level of observation is the household, as reflected in the primary taxpayer observation which aggregates spousal income. California AGI differs from Federal AGI in two ways: (a) it includes only California source income; and (b) California and Federal law differ slightly in their definitions of AGI. 
Table 2: Increase in Average Tax Rate Difference between California and Other States, 2012-13

\begin{tabular}{l|l|lll} 
Income Bin & \multirow{2}{*}{ Only Prop 30 } & \multicolumn{3}{|c}{ Prop $30+$ Federal Tax Increase } \\
& & Zero Tax States & Non-Zero Tax States & Tax Cuts \\
\hline 10.3\% Bracket & 0.0022 & -0.0077 & -0.0029 & 0.0056 \\
$11.3 \%$ Bracket & 0.0061 & -0.0009 & 0.0004 & 0.0082 \\
$12.3 \%$ Bracket & 0.0125 & 0.0107 & 0.0082 & 0.0163 \\
\$2-5 Million & 0.0181 & 0.0166 & 0.0118 & 0.0204 \\
\$5+ Million & 0.0225 & 0.0187 & 0.0141 & 0.0219
\end{tabular}

For this table, each taxpayer $i$ is sorted into an income bin $B$ based on their 2012 income. For each such group, the column "Only Prop 30" reports how Proposition 30 altered incentives to leave California, averaged over individuals and destination states. Note that if $T_{2012}^{S}\left(z_{i, 2012}\right)=T_{2011}^{S}\left(z_{i, 2012}\right)$ - that is, the destination state does not change tax policy between 2011 and 2012 - the quantity collapses to $T_{2012}^{C A}\left(z_{i, 2012}\right)-T_{2011}^{C A}\left(z_{i, 2012}\right)$. Differences between the effective increase in the average tax rate and the increase in the top marginal rate are due to the federal deductibility of state taxes and the discrepancy between average and marginal tax rates. In the remaining columns, we account for how this increase in move-out incentives is altered by the concurrent 2012-13 increase in federal tax rates, which induce variation in cross-state movement incentives due to the interaction of the federal policy shift with the existing state of tax deductions in non-California states. We report such averages in the "Prop 30 + Federal Tax Increase" columns of the table. To provide a broad picture of this heterogeneity, we split the destination states into three groups in the latter columns: (1) zero-tax states, which have zero state income taxes in 2012 and 2013; (2) non-zero tax states which tax income but do not change tax policy between 2012-13 (3) the states of Iowa, Kansas and Maine separately because these states enacted tax cuts. See Section $5 . a .3$ for further details. 
Table 3: Movement Regressions: Taxable Income Weighted

\begin{tabular}{|c|c|c|c|c|c|c|}
\hline & \multicolumn{6}{|c|}{ Mover Type } \\
\hline & \multicolumn{2}{|c|}{ Next Year NR/Partial } & \multicolumn{2}{|c|}{ Next 2 Years NR/Partial } & \multicolumn{2}{|c|}{ Next year NR, Then Missing } \\
\hline & $(1)$ & $(2)$ & $(3)$ & $(4)$ & $(5)$ & $(6)$ \\
\hline \multicolumn{7}{|l|}{$10.3 \%$ Bracket } \\
\hline $\mathbf{1}\{2011\}$ & $\begin{array}{c}0.002^{* *} \\
(0.001)\end{array}$ & $\begin{array}{c}0.002^{* * *} \\
(0.001)\end{array}$ & $\begin{array}{l}0.001^{*} \\
(0.001)\end{array}$ & $\begin{array}{l}0.001^{*} \\
(0.001)\end{array}$ & $\begin{array}{c}0.001^{*} \\
(0.0005)\end{array}$ & $\begin{array}{l}0.001^{* *} \\
(0.0005)\end{array}$ \\
\hline $\mathbf{1}\{2012\}$ & $\begin{array}{c}0.003^{* * *} \\
(0.001)\end{array}$ & $\begin{array}{c}0.003^{* * *} \\
(0.001)\end{array}$ & $\begin{array}{c}0.002^{* * *} \\
(0.001)\end{array}$ & $\begin{array}{c}0.002^{* * *} \\
(0.001)\end{array}$ & $\begin{array}{l}0.001^{* *} \\
(0.0005)\end{array}$ & $\begin{array}{l}0.001^{* *} \\
(0.0005)\end{array}$ \\
\hline $\mathbf{1}\{2013\}$ & $\begin{array}{l}0.001^{*} \\
(0.001)\end{array}$ & $\begin{array}{l}0.002^{*} \\
(0.001)\end{array}$ & $\begin{array}{c}0.001 \\
(0.0005)\end{array}$ & $\begin{array}{c}0.001 \\
(0.0005)\end{array}$ & $\begin{array}{c}0.001 \\
(0.0004)\end{array}$ & $\begin{array}{c}0.001 \\
(0.0004)\end{array}$ \\
\hline \multicolumn{7}{|l|}{ 11.3\% Bracket } \\
\hline $\mathbf{1}\{2011\}$ & $\begin{array}{c}0.002^{* * *} \\
(0.001)\end{array}$ & $\begin{array}{c}0.002^{* * *} \\
(0.001)\end{array}$ & $\begin{array}{l}0.001^{* *} \\
(0.0004)\end{array}$ & $\begin{array}{c}0.001^{* *} \\
(0.0004)\end{array}$ & $\begin{array}{c}0.001^{*} \\
(0.0003)\end{array}$ & $\begin{array}{c}0.001^{*} \\
(0.0003)\end{array}$ \\
\hline $\mathbf{1}\{2012\}$ & $\begin{array}{c}0.003^{* * *} \\
(0.001)\end{array}$ & $\begin{array}{c}0.003^{* * *} \\
(0.001)\end{array}$ & $\begin{array}{c}0.002^{* * *} \\
(0.0004)\end{array}$ & $\begin{array}{l}0.002^{* * *} \\
(0.0004)\end{array}$ & $\begin{array}{c}0.001^{* * *} \\
(0.0003)\end{array}$ & $\begin{array}{l}0.001^{* * *} \\
(0.0003)\end{array}$ \\
\hline $\mathbf{1}\{2013\}$ & $\begin{array}{c}0.001^{*} \\
(0.0005)\end{array}$ & $\begin{array}{l}0.001^{*} \\
(0.001)\end{array}$ & $\begin{array}{c}0.0004 \\
(0.0004)\end{array}$ & $\begin{array}{c}0.0005 \\
(0.0004)\end{array}$ & $\begin{array}{c}0.001 \\
(0.0003)\end{array}$ & $\begin{array}{c}0.001 \\
(0.0003)\end{array}$ \\
\hline \multicolumn{7}{|l|}{ 12.3\% Bracket } \\
\hline $\mathbf{1}\{2011\}$ & $\begin{array}{c}0.002 \\
(0.001)\end{array}$ & $\begin{array}{c}0.002 \\
(0.001)\end{array}$ & $\begin{array}{c}0.001 \\
(0.001)\end{array}$ & $\begin{array}{c}0.001 \\
(0.001)\end{array}$ & $\begin{array}{c}0.002 \\
(0.001)\end{array}$ & $\begin{array}{c}0.002 \\
(0.001)\end{array}$ \\
\hline $\mathbf{1}\{2012\}$ & $\begin{array}{c}0.008^{* *} \\
(0.003)\end{array}$ & $\begin{array}{c}0.008^{* *} \\
(0.003)\end{array}$ & $\begin{array}{c}0.005^{* *} \\
(0.002)\end{array}$ & $\begin{array}{c}0.005^{* *} \\
(0.002)\end{array}$ & $\begin{array}{c}0.003 \\
(0.002)\end{array}$ & $\begin{array}{c}0.003 \\
(0.002)\end{array}$ \\
\hline $\mathbf{1}\{2013\}$ & $\begin{array}{c}0.002 \\
(0.001)\end{array}$ & $\begin{array}{c}0.002 \\
(0.001)\end{array}$ & $\begin{array}{c}0.002 \\
(0.001)\end{array}$ & $\begin{array}{c}0.002 \\
(0.001)\end{array}$ & $\begin{array}{c}0.001 \\
(0.0004)\end{array}$ & $\begin{array}{c}0.001 \\
(0.0004)\end{array}$ \\
\hline Income Controls & & $\times$ & & $\times$ & & $\times$ \\
\hline Observations & $43,851,430$ & $43,851,430$ & $43,851,430$ & $43,851,430$ & $43,851,430$ & $43,851,430$ \\
\hline $\mathrm{R}^{2}$ & 0.001 & 0.001 & 0.001 & 0.001 & 0.002 & 0.002 \\
\hline Adjusted $\mathrm{R}^{2}$ & 0.001 & 0.001 & 0.001 & 0.001 & 0.002 & 0.002 \\
\hline
\end{tabular}

Regressions include years 2000-2013 but exclude all taxpayers below the $9.3 \%$ bracket. All

specifications contain marital status and year fixed effects. 2000-2010 is the pre-period, and differences in differences effects are estimated for years 2011-13. Standard errors are clustered by taxpayer. Income controls include log income and fixed effects for 100 income percentiles. Regressions are weighted by taxable income.

${ }^{*} \mathrm{p}<0.05 ;{ }^{* *} \mathrm{p}<0.01 ;{ }^{* *} \mathrm{p}<0.001$ 
Table 4: Movement Regressions: Unweighted, Granular Bins

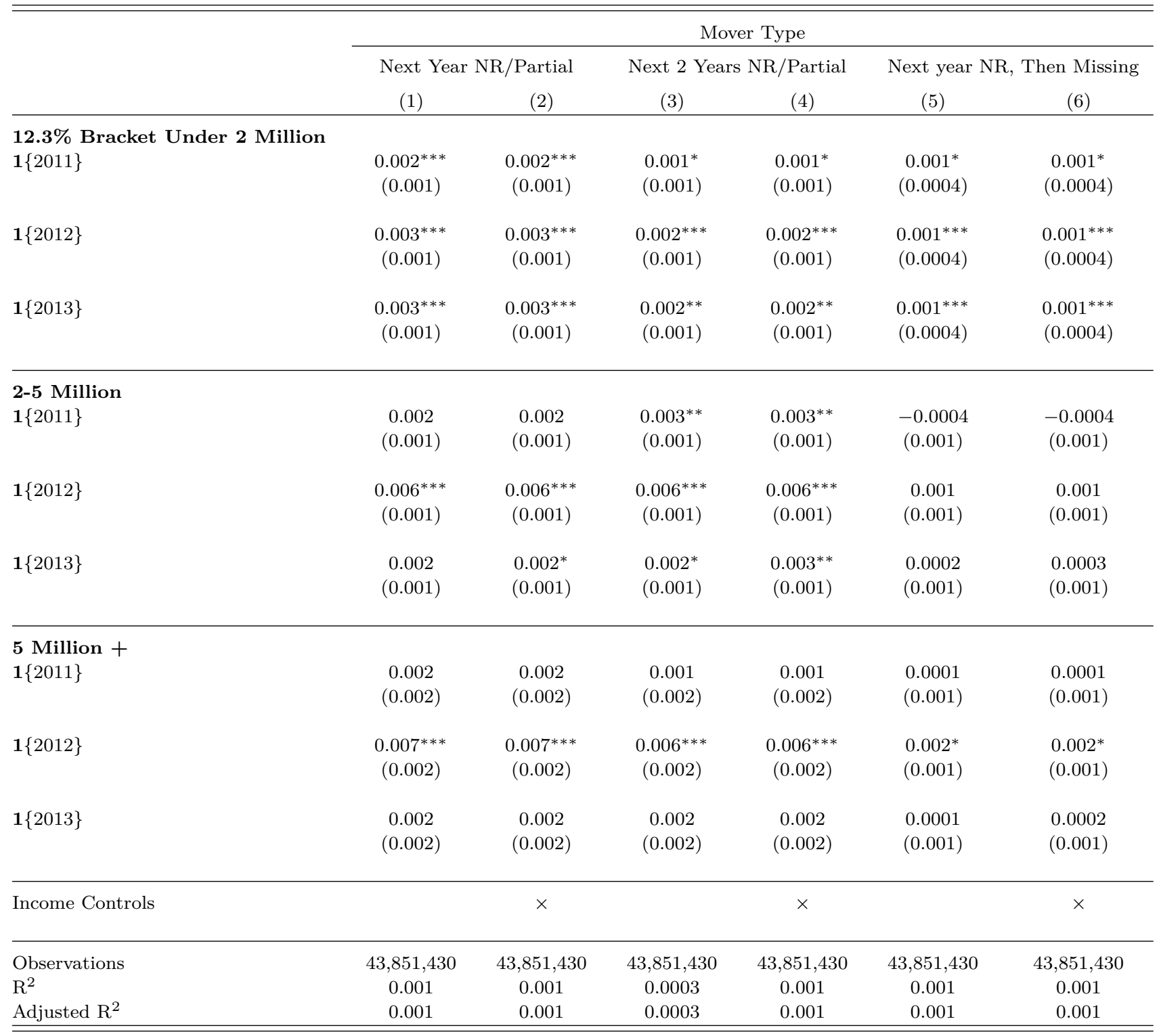

Regressions include years 2000-2013 but also exclude all taxpayers below the $9.3 \%$ bracket. All specifications contain marital status and year fixed effects. 2000-2010 is the "pre" period, and differences in differences effects are estimated for years 2011-13. Standard errors are clustered by taxpayer. Income controls include log income and fixed effects for 100 income percentiles.

${ }^{*} \mathrm{p}<0.05 ;{ }^{* *} \mathrm{p}<0.01 ;{ }^{* * *} \mathrm{p}<0.001$ 
Table 5: Movement Regressions: Income Weighted, Top-Bracket Persistence

\begin{tabular}{|c|c|c|c|c|}
\hline & \multicolumn{4}{|c|}{ Next Year Non Resident } \\
\hline & $(1)$ & $(2)$ & $(3)$ & $(4)$ \\
\hline \multicolumn{5}{|l|}{ 10.3\% Bracket } \\
\hline $\mathbf{1}\{2011\}$ & $\begin{array}{c}0.002^{* * *} \\
(0.001)\end{array}$ & $\begin{array}{c}0.003^{* * *} \\
(0.001)\end{array}$ & $\begin{array}{c}0.002^{* * *} \\
(0.001)\end{array}$ & $\begin{array}{c}0.003^{* * *} \\
(0.001)\end{array}$ \\
\hline $\mathbf{1}\{2012\}$ & $\begin{array}{c}0.003^{* * *} \\
(0.001)\end{array}$ & $\begin{array}{c}0.003^{* * *} \\
(0.001)\end{array}$ & $\begin{array}{c}0.003^{* * *} \\
(0.001)\end{array}$ & $\begin{array}{c}0.003^{* * *} \\
(0.001)\end{array}$ \\
\hline $\mathbf{1}\{2013\}$ & $\begin{array}{l}0.002^{*} \\
(0.001)\end{array}$ & $\begin{array}{c}0.002^{* *} \\
(0.001)\end{array}$ & $\begin{array}{l}0.002^{*} \\
(0.001)\end{array}$ & $\begin{array}{c}0.002^{* *} \\
(0.001)\end{array}$ \\
\hline \multicolumn{5}{|l|}{ 11.3\% Bracket } \\
\hline $\mathbf{1}\{2011\}$ & $\begin{array}{c}0.002^{* * *} \\
(0.001)\end{array}$ & $\begin{array}{c}0.002^{* * *} \\
(0.001)\end{array}$ & $\begin{array}{c}0.002^{* * *} \\
(0.001)\end{array}$ & $\begin{array}{c}0.002^{* * *} \\
(0.001)\end{array}$ \\
\hline $\mathbf{1}\{2012\}$ & $\begin{array}{c}0.003^{* * *} \\
(0.001)\end{array}$ & $\begin{array}{c}0.003^{* * *} \\
(0.001)\end{array}$ & $\begin{array}{c}0.003^{* * *} \\
(0.001)\end{array}$ & $\begin{array}{c}0.003^{* * *} \\
(0.001)\end{array}$ \\
\hline $\mathbf{1}\{2013\}$ & $\begin{array}{l}0.001^{*} \\
(0.001)\end{array}$ & $\begin{array}{l}0.001^{*} \\
(0.001)\end{array}$ & $\begin{array}{l}0.001^{*} \\
(0.001)\end{array}$ & $\begin{array}{l}0.001^{*} \\
(0.001)\end{array}$ \\
\hline \multicolumn{5}{|l|}{$12.3 \%$ Bracket } \\
\hline $\mathbf{1}\{2011\}$ & $\begin{array}{c}0.003 \\
(0.001)\end{array}$ & $\begin{array}{c}0.003 \\
(0.001)\end{array}$ & $\begin{array}{c}0.001 \\
(0.002)\end{array}$ & $\begin{array}{c}0.001 \\
(0.002)\end{array}$ \\
\hline $\mathbf{1}\{2012\}$ & $\begin{array}{c}0.008^{* *} \\
(0.003)\end{array}$ & $\begin{array}{c}0.009^{* * *} \\
(0.003)\end{array}$ & $\begin{array}{c}0.003 \\
(0.002)\end{array}$ & $\begin{array}{c}0.003 \\
(0.002)\end{array}$ \\
\hline $\mathbf{1}\{2013\}$ & $\begin{array}{l}0.003^{*} \\
(0.001)\end{array}$ & $\begin{array}{c}0.003^{*} \\
(0.001)\end{array}$ & $\begin{array}{c}0.003 \\
(0.002)\end{array}$ & $\begin{array}{l}0.003^{*} \\
(0.002)\end{array}$ \\
\hline \multicolumn{5}{|c|}{ 3-Year Top Bracket } \\
\hline $\mathbf{1}\{2011\}$ & & & $\begin{array}{c}0.004 \\
(0.002)\end{array}$ & $\begin{array}{c}0.004 \\
(0.002)\end{array}$ \\
\hline $\mathbf{1}\{2012\}$ & & & $\begin{array}{c}0.009^{* *} \\
(0.003)\end{array}$ & $\begin{array}{c}0.009^{* *} \\
(0.003)\end{array}$ \\
\hline $\mathbf{1}\{2013\}$ & & & $\begin{array}{c}0.003 \\
(0.002)\end{array}$ & $\begin{array}{c}0.003 \\
(0.002)\end{array}$ \\
\hline Income Controls & & $x$ & & $\times$ \\
\hline Observations & $35,289,187$ & $35,289,187$ & $35,265,965$ & $35,265,965$ \\
\hline $\mathrm{R}^{2}$ & 0.001 & 0.001 & 0.001 & 0.001 \\
\hline Adjusted $\mathrm{R}^{2}$ & 0.001 & 0.001 & 0.001 & 0.001 \\
\hline
\end{tabular}

Regressions include years 2003-2013 but exclude all taxpayers below the $9.3 \%$ bracket. All specifications contain marital status and year fixed effects. 2003-2010 is the pre-period, and differences in differences effects are estimated for years 2011-13. Standard errors are clustered by taxpayer. Income controls include log income and fixed effects for 100 income percentiles. Regressions weighted by taxable income. "3-year top bracket" denotes those taxpayers who in year $t, t-1$ and $t-2$ report top-bracket taxable income. ${ }^{*} \mathrm{p}<0.05 ;{ }^{* *} \mathrm{p}<0.01 ;{ }^{* * *} \mathrm{p}<0.001$ 
Table 6: Covariate Balance: 2011 values

\begin{tabular}{|c|c|c|c|c|c|c|}
\hline Statistic & $\mathrm{N}$ & Mean & St. Dev. & $\operatorname{Pctl}(25)$ & Median & $\operatorname{Pctl}(75)$ \\
\hline \multicolumn{7}{|l|}{ Resident } \\
\hline Federal AGI & 21,033 & 4.24 & 12.82 & 1.31 & 1.98 & 3.64 \\
\hline Taxable Income & 21,033 & 4.15 & 11.56 & 1.29 & 1.96 & 3.61 \\
\hline Capital Gains & 21,033 & 0.91 & 8.83 & -0.003 & 0.00 & 0.06 \\
\hline Married & 21,033 & 0.67 & 0.47 & 0 & 1 & 1 \\
\hline Single & 21,033 & 0.30 & 0.46 & 0 & 0 & 1 \\
\hline Age & 21,033 & 54.90 & 13.97 & 47 & 54 & 63 \\
\hline \multicolumn{7}{|l|}{ Non Resident } \\
\hline Federal AGI & 13,419 & 7.89 & 27.01 & 1.50 & 2.57 & 5.51 \\
\hline Taxable Income & 13,419 & 7.54 & 24.23 & 1.52 & 2.50 & 5.19 \\
\hline Capital Gains & 13,419 & 2.15 & 18.22 & -0.003 & 0 & 0.2 \\
\hline Married & 13,419 & 0.73 & 0.44 & 0 & 1 & 1 \\
\hline Single & 13,419 & 0.24 & 0.43 & 0 & 0 & 0 \\
\hline Age & 13,419 & 54.26 & 13.36 & 47 & 54 & 62 \\
\hline \multicolumn{7}{|c|}{ Non Resident, Matched } \\
\hline Federal AGI & 21,033 & 4.17 & 13.54 & 1.30 & 1.96 & 3.63 \\
\hline Taxable Income & 21,033 & 4.08 & 11.80 & 1.34 & 1.96 & 3.48 \\
\hline Capital Gains & 21,033 & 1.02 & 8.95 & -0.003 & 0.00 & 0.09 \\
\hline Married & 21,033 & 0.68 & 0.46 & 0 & 1 & 1 \\
\hline Single & 21,033 & 0.29 & 0.45 & 0 & 0 & 1 \\
\hline Age & 21,033 & 53.89 & 13.32 & 46 & 54 & 62 \\
\hline \multicolumn{7}{|c|}{ Non Resident, Matched, Tax-Similar States } \\
\hline Federal AGI & 21,033 & 4.04 & 11.95 & 1.29 & 1.96 & 3.62 \\
\hline Taxable Income & 21,033 & 4.04 & 10.09 & 1.32 & 1.96 & 3.44 \\
\hline Capital Gains & 21,033 & 0.93 & 7.36 & -0.003 & 0.00 & 0.07 \\
\hline Married & 21,033 & 0.66 & 0.47 & 0 & 1 & 1 \\
\hline Single & 21,033 & 0.31 & 0.46 & 0 & 0 & 1 \\
\hline Age & 21,033 & 52.83 & 12.40 & 45 & 52 & 60 \\
\hline
\end{tabular}

The Resident sample consists of taxpayers who from 2009 to 2011 filed as California residents, and further who for each year earned taxable income which placed them in the range of the top-bracket as newly introduced by California Proposition 30. The Non-Resident sample is the matched sample of non-residents. Matching is done on 2009-10 data, using the total value of income across those two years for three separate variables: Federal AGI, Taxable Income, and Capital Gains. The table compares compares 2011 covariate values. For the "Tax Similar States" sample, the control pool used is Hawaii (11\% top rate), Oregon (9.9\% top rate), Minnesota (9.85\% top rate), Iowa ( $8.98 \%$ top rate), New Jersey ( $8.97 \%$ top rate), Vermont (8.95\% top rate), District of Columbia (8.95\% top rate), and New York (8.82\% top rate). Taxable Income for California residents is their California taxable income. For California non-residents, Taxable Income is the taxable income of the taxpayer if they had been a California resident and their full income had been subject to California state taxation. 
Table 7: Matched Differences in Differences: Main Estimates

\begin{tabular}{|c|c|c|c|c|}
\hline & \multicolumn{4}{|c|}{ Dependent Variable } \\
\hline & $\log ($ Taxable Income +1$)$ & Taxable Income (Millions) & $\log ($ Federal AGI + 1) & Federal AGI (Millions) \\
\hline & $(1)$ & $(2)$ & $(3)$ & $(4)$ \\
\hline Resident $\times 2011$ & $\begin{array}{l}-0.005 \\
(0.008)\end{array}$ & $\begin{array}{l}-0.079 \\
(0.065)\end{array}$ & $\begin{array}{l}-0.014 \\
(0.009)\end{array}$ & $\begin{array}{l}-0.046 \\
(0.079)\end{array}$ \\
\hline Resident $\times 2012$ & $\begin{array}{c}-0.134^{* * *} \\
(0.023)\end{array}$ & $\begin{array}{c}-0.522^{* * *} \\
(0.096)\end{array}$ & $\begin{array}{c}-0.097^{* * *} \\
(0.012)\end{array}$ & $\begin{array}{c}-0.340^{* * *} \\
(0.095)\end{array}$ \\
\hline Resident $\times 2013$ & $\begin{array}{c}-0.174^{* * *} \\
(0.034)\end{array}$ & $\begin{array}{c}-0.357^{* * *} \\
(0.077)\end{array}$ & $\begin{array}{c}-0.117^{* * *} \\
(0.014)\end{array}$ & $\begin{array}{c}-0.297^{* * *} \\
(0.084)\end{array}$ \\
\hline Resident $\times 2014$ & $\begin{array}{c}-0.282^{* * *} \\
(0.035)\end{array}$ & $\begin{array}{c}-0.599^{* * *} \\
(0.092)\end{array}$ & $\begin{array}{c}-0.194^{* * *} \\
(0.015)\end{array}$ & $\begin{array}{c}-0.546^{* * *} \\
(0.098)\end{array}$ \\
\hline Threshold Parallel Trend $M$ & 0.062 & 0.164 & 0.054 & - \\
\hline Observations & 178,782 & 178,782 & 177,416 & 178,782 \\
\hline $\mathrm{R}^{2}$ & 0.447 & 0.702 & 0.729 & 0.707 \\
\hline Adjusted $\mathrm{R}^{2}$ & 0.336 & 0.642 & 0.675 & 0.649 \\
\hline
\end{tabular}

All regressions include taxpayer fixed effects. California residents are weighted to 1 ; the California non-resident control group has weights applied with mean 1 and reflecting matched sample with replacement. 2009-10 is the pre-period. Levels variables are winsorized at 99.5\%. Standard errors are clustered by taxpayer. "Taxable Income" is under the California definition. That is, for California residents it is their California taxable income. For California non-residents, it is the taxable income of the taxpayer if they were a California resident and their full income were subject to California state taxation. "Threshold Parallel Trend $M$ " is defined as the highest value of $M$ in the Rambachan-Roth (2019) procedure for which the entire $95 \%$ confidence interval for the 2012 treatment lies below zero, with values of $M>0$ reflecting robustness even to the possibility of nonlinear departure from parallel trends. The $95 \%$ confidence interval for the 2012 treatment at $M=0$ (allowing for linear violation of parallel trends) for the Federal AGI level is $[-0.399,0.037]$

${ }^{*} \mathrm{p}<0.05 ;{ }^{* *} \mathrm{p}<0.01 ;{ }^{* * *} \mathrm{p}<0.001$ 
Table 8: Matched Differences in Differences: Similar-Tax States Control Group Restriction

\begin{tabular}{|c|c|c|c|c|}
\hline & \multicolumn{4}{|c|}{ Dependent Variable } \\
\hline & $\begin{array}{c}\log (\text { Taxable Income }+1) \\
(1)\end{array}$ & $\begin{array}{c}\text { Taxable Income (Millions) } \\
(2)\end{array}$ & $\begin{array}{c}\log (\text { Federal AGI + } 1) \\
(3)\end{array}$ & $\begin{array}{c}\text { Federal AGI (Millions) } \\
\qquad(4)\end{array}$ \\
\hline Resident $\times 2011$ & $\begin{array}{l}-0.007 \\
(0.012)\end{array}$ & $\begin{array}{l}-0.050 \\
(0.093)\end{array}$ & $\begin{array}{l}-0.009 \\
(0.012)\end{array}$ & $\begin{array}{l}-0.072 \\
(0.095)\end{array}$ \\
\hline Resident $\times 2012$ & $\begin{array}{c}-0.150^{* * *} \\
(0.027)\end{array}$ & $\begin{array}{c}-0.352^{* *} \\
(0.133)\end{array}$ & $\begin{array}{c}-0.062^{* * *} \\
(0.017)\end{array}$ & $\begin{array}{l}-0.180 \\
(0.146)\end{array}$ \\
\hline Resident $\times 2013$ & $\begin{array}{c}-0.215^{* * *} \\
(0.043)\end{array}$ & $\begin{array}{c}-0.373^{* * *} \\
(0.103)\end{array}$ & $\begin{array}{c}-0.101^{* * *} \\
(0.021)\end{array}$ & $\begin{array}{c}-0.307^{*} \\
(0.135)\end{array}$ \\
\hline Resident × 2014 & $\begin{array}{c}-0.324^{* * *} \\
(0.045)\end{array}$ & $\begin{array}{c}-0.481^{* * *} \\
(0.117)\end{array}$ & $\begin{array}{c}-0.189^{* * *} \\
(0.022)\end{array}$ & $\begin{array}{c}-0.417^{* *} \\
(0.140)\end{array}$ \\
\hline Observations & 151,512 & 151,512 & 150,493 & 151,512 \\
\hline $\mathrm{R}^{2}$ & 0.450 & 0.702 & 0.721 & 0.730 \\
\hline Adjusted $\mathrm{R}^{2}$ & 0.340 & 0.643 & 0.665 & 0.676 \\
\hline
\end{tabular}


Table 9: Matched Differences in Differences: Income Decomposition

\begin{tabular}{|c|c|c|c|c|c|c|c|c|}
\hline & \multicolumn{8}{|c|}{ Dependent Variable } \\
\hline & $\begin{array}{c}\text { Taxable Income } \\
(1) \\
\end{array}$ & $\begin{array}{c}\text { Federal AGI } \\
(2) \\
\end{array}$ & $\begin{array}{c}\text { Deductions } \\
(3) \\
\end{array}$ & $\begin{array}{c}\text { Taxable Income - } \\
\text { Investment Income } \\
(4) \\
\end{array}$ & $\begin{array}{c}\text { Federal AGI - } \\
\text { Investment Income } \\
(5) \\
\end{array}$ & $\begin{array}{c}\text { Investment Income } \\
(6) \\
\end{array}$ & $\begin{array}{l}\text { Capital Gains } \\
(7) \\
\end{array}$ & $\begin{array}{c}\text { Dividend + } \\
\text { Interest } \\
(8) \\
\end{array}$ \\
\hline Resident $\times 2011$ & $\begin{array}{l}-0.049 \\
(0.068)\end{array}$ & $\begin{array}{c}0.051 \\
(0.083)\end{array}$ & $\begin{array}{c}0.100 \\
(0.053)\end{array}$ & $\begin{array}{l}-0.079 \\
(0.099)\end{array}$ & $\begin{array}{c}0.026 \\
(0.105)\end{array}$ & $\begin{array}{c}0.024 \\
(0.121)\end{array}$ & $\begin{array}{c}0.048 \\
(0.114)\end{array}$ & $\begin{array}{l}-0.023 \\
(0.034)\end{array}$ \\
\hline Resident $\times 2012$ & $\begin{array}{c}-0.492^{* * *} \\
(0.090)\end{array}$ & $\begin{array}{c}-0.243^{* *} \\
(0.092)\end{array}$ & $\begin{array}{c}0.249^{* * *} \\
(0.045)\end{array}$ & $\begin{array}{c}-0.648^{* * *} \\
(0.040)\end{array}$ & $\begin{array}{c}-0.399^{* *} \\
(0.128)\end{array}$ & $\begin{array}{c}0.156 \\
(0.123)\end{array}$ & $\begin{array}{c}0.210 \\
(0.152)\end{array}$ & $\begin{array}{l}-0.054 \\
(0.144)\end{array}$ \\
\hline Resident $\times 2013$ & $\begin{array}{c}-0.328^{* * *} \\
(0.078)\end{array}$ & $\begin{array}{c}-0.200^{*} \\
(0.088)\end{array}$ & $\begin{array}{c}0.127^{* * *} \\
(0.038)\end{array}$ & $\begin{array}{c}-0.493^{* * *} \\
(0.124)\end{array}$ & $\begin{array}{c}-0.366^{* *} \\
(0.124)\end{array}$ & $\begin{array}{c}0.165 \\
(0.139)\end{array}$ & $\begin{array}{c}0.213 \\
(0.129)\end{array}$ & $\begin{array}{l}-0.047 \\
(0.042)\end{array}$ \\
\hline Threshold Parallel Trend $M$ & 0.168 & 0.099 & - & 0.109 & - & - & - & - \\
\hline $\begin{array}{l}\text { Observations } \\
\mathrm{R}^{2} \\
\text { Adjusted } \mathrm{R}^{2}\end{array}$ & $\begin{array}{c}119,188 \\
0.754 \\
0.671\end{array}$ & $\begin{array}{c}119,188 \\
0.753 \\
0.671\end{array}$ & $\begin{array}{c}119,188 \\
0.531 \\
0.375\end{array}$ & $\begin{array}{c}119,188 \\
0.655 \\
0.540\end{array}$ & $\begin{array}{c}119,188 \\
0.643 \\
0.524\end{array}$ & $\begin{array}{c}119,188 \\
0.678 \\
0.570\end{array}$ & $\begin{array}{c}119,188 \\
0.631 \\
0.507\end{array}$ & $\begin{array}{c}119,188 \\
0.684 \\
0.579\end{array}$ \\
\hline
\end{tabular}

"Investment Income" is the sum of capital gains, dividends, and interest. All regressions include taxpayer fixed effects. California residents are weighted to 1; California nonresident control group has weights applied with mean 1 and reflecting matched sample with replacement. 2010 is the pre-period. Standard errors are clustered by taxpayer. All variables are denominated in millions of 2015 dollars. "Taxable Income" is under the California definition. That is, for California residents it is their California taxable income. For California non-residents, it is the taxable income of the taxpayer if they were a California resident and their full income were subject to California state taxation. Threshold Parallel Trend $M$ is defined as the highest value of $\mathrm{M}$ in the Rambachan-Roth (2019) procedure for which the entire $95 \%$ confidence interval for the 2012 treatment lies below zero, with values of $\mathrm{M}>0$ reflecting robustness even to the possibility of nonlinear departure from parallel trends.

${ }^{*} \mathrm{p}<0.05 ;{ }^{* *} \mathrm{p}<0.01 ;{ }^{* * *} \mathrm{p}<0.001$ 


\section{Appendix - For Online Publication}

\section{A. Supplemental Tables and Figures}

Table A1: California FTB Inflation Index

\begin{tabular}{l|l} 
Year & Inflation Factor (Percent) \\
\hline $2000-01$ & 5.3 \\
$2001-02$ & 1.5 \\
$2002-03$ & 2.2 \\
$2003-04$ & 3.1 \\
$2004-05$ & 2.8 \\
$2005-06$ & 4.8 \\
$2006-07$ & 3.1 \\
$2007-08$ & 5.0 \\
$2008-09$ & -1.5 \\
$2009-10$ & 0.9 \\
$2010-11$ & 2.7 \\
$2011-12$ & 1.9 \\
$2012-13$ & 1.7 \\
$2013-14$ & 2.2 \\
$2014-15$ & 1.3 \\
$2015-16$ & 2.1
\end{tabular}


Table A2: Out-Migration Summary Statistics, 2000-09

\begin{tabular}{cccc}
\hline \hline \multirow{2}{*}{ Income Bin } & \multicolumn{3}{c}{ Percentage Chance of Next-Year Non Resident Filing } \\
\cline { 2 - 4 } All & To Non-Filer & To Non-Resident Filer \\
\hline \$5 Million & 1.524 & 0.467 & 1.012 \\
\$2-5 Million & 1.521 & 0.567 & 0.905 \\
$12.3 \%$ Under $\$ 2$ Million & 1.590 & 0.663 & 0.859 \\
$11.3 \%$ & 1.597 & 0.795 & 0.726 \\
$10.3 \%$ & 1.712 & 0.911 & 0.710 \\
$9.3 \%$ & 1.682 & 1.134 & 0.439 \\
\hline
\end{tabular}

This table reports the percentage likelihood of different modes of out-migration, disaggregated by income bins reported in 2015 dollars. The calculations omit taxpayers who in the next year file as a non-resident, only to file again as a resident in the subsequent year (these are not quantitatively important). Out-migration rates are unweighted. 
Table A3: Increase in Average Log Net-of-Tax Rate Differences, 2012-13

\begin{tabular}{l|l|lll} 
Income Bin & Only Prop 30 & \multicolumn{3}{|c}{ Prop 30 + Federal Tax Increase } \\
& & Zero Tax States & Non-Zero Tax States & Tax Cuts \\
\hline $10.3 \%$ Bracket & .0039 & -.0066 & -.0026 & .0097 \\
$11.3 \%$ Bracket & .0100 & .0060 & .0037 & .0150 \\
$12.3 \%$ Bracket & .0202 & .0296 & .0190 & .0311 \\
$\$ 2-5$ Million & .0296 & .0450 & .0288 & .0421 \\
$\$ 5+$ Million & .0363 & .0504 & .0340 & .0457
\end{tabular}

This table proceeds identically to Table 2, calculating changes in the tax rate differences between California and other states. The difference compared to Table 2 is that we use the log net of tax average rate. See note to Table 2 for explanation. 


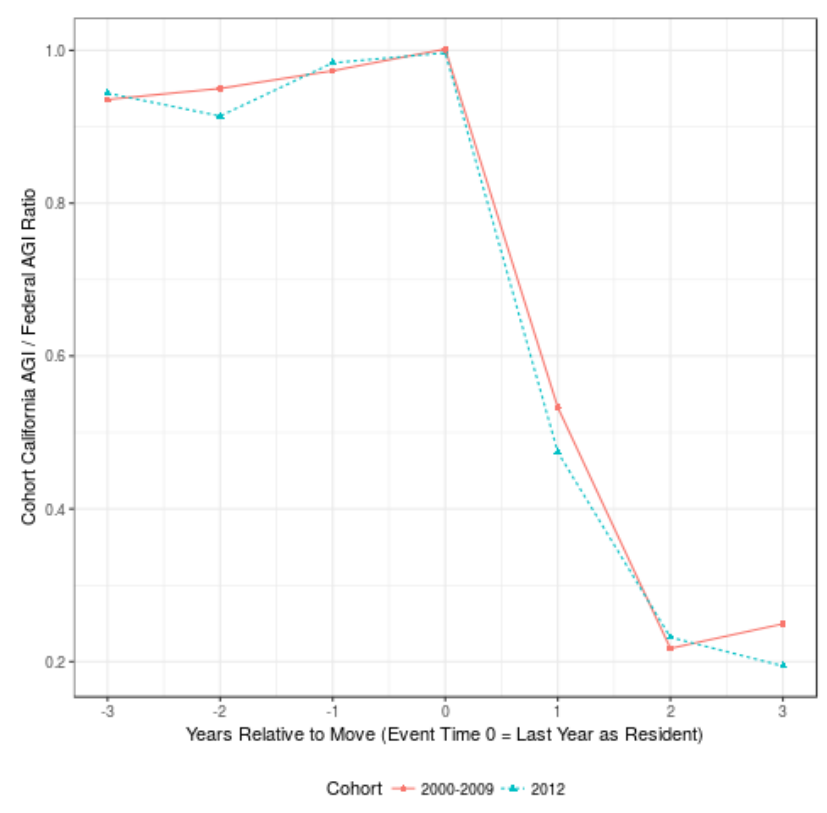

(a) California AGI / Federal AGI Ratio

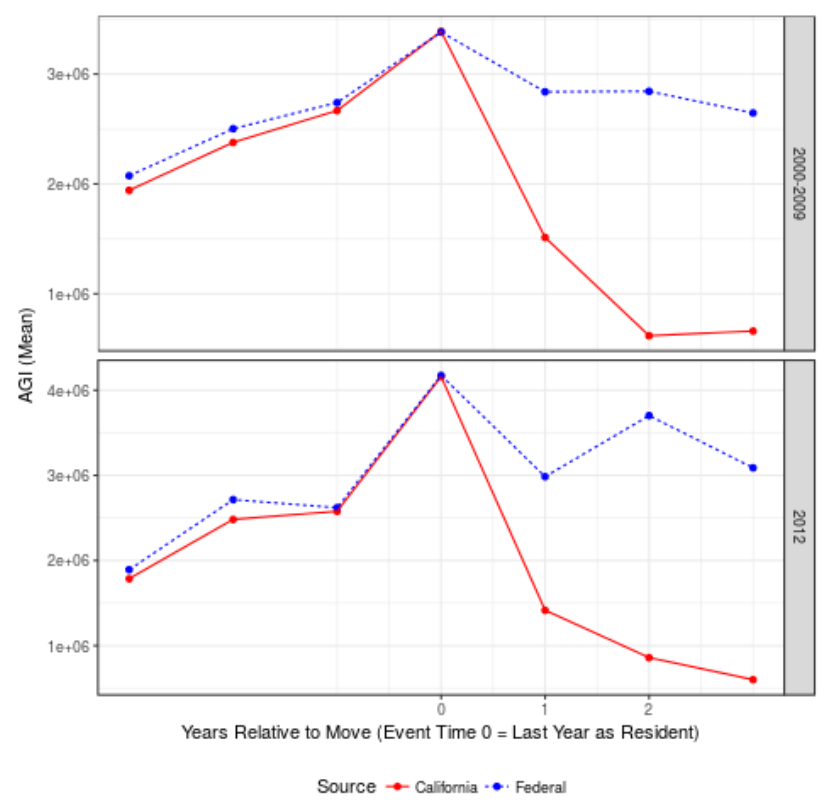

(b) AGI Levels

Figure A1: AGI Dynamics of Top-Bracket Resident Filter to 2x Non-Resident/Partial Year Filer

The sample is all taxpayers who displayed a Resident - NR - NR transition, where in the "Resident" year the taxpayer was in the top tax bracket according to 2012 tax policy. 


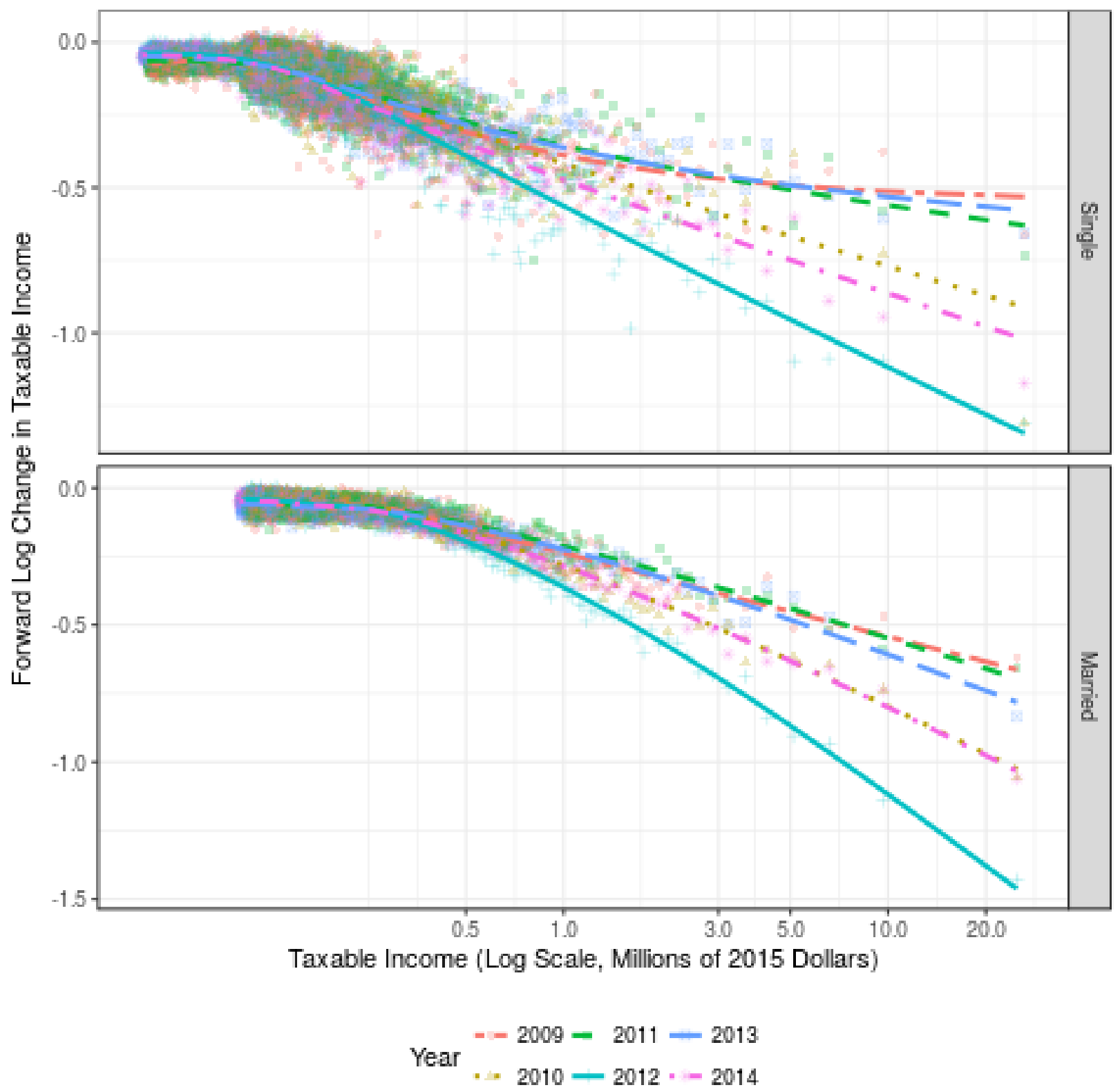

Figure A2: Year on Year Log Change in Income, by Income and Year

This figure shows the forward log change in taxable income across each of 2000 taxable income bins, for each tax year 2009-2014. 


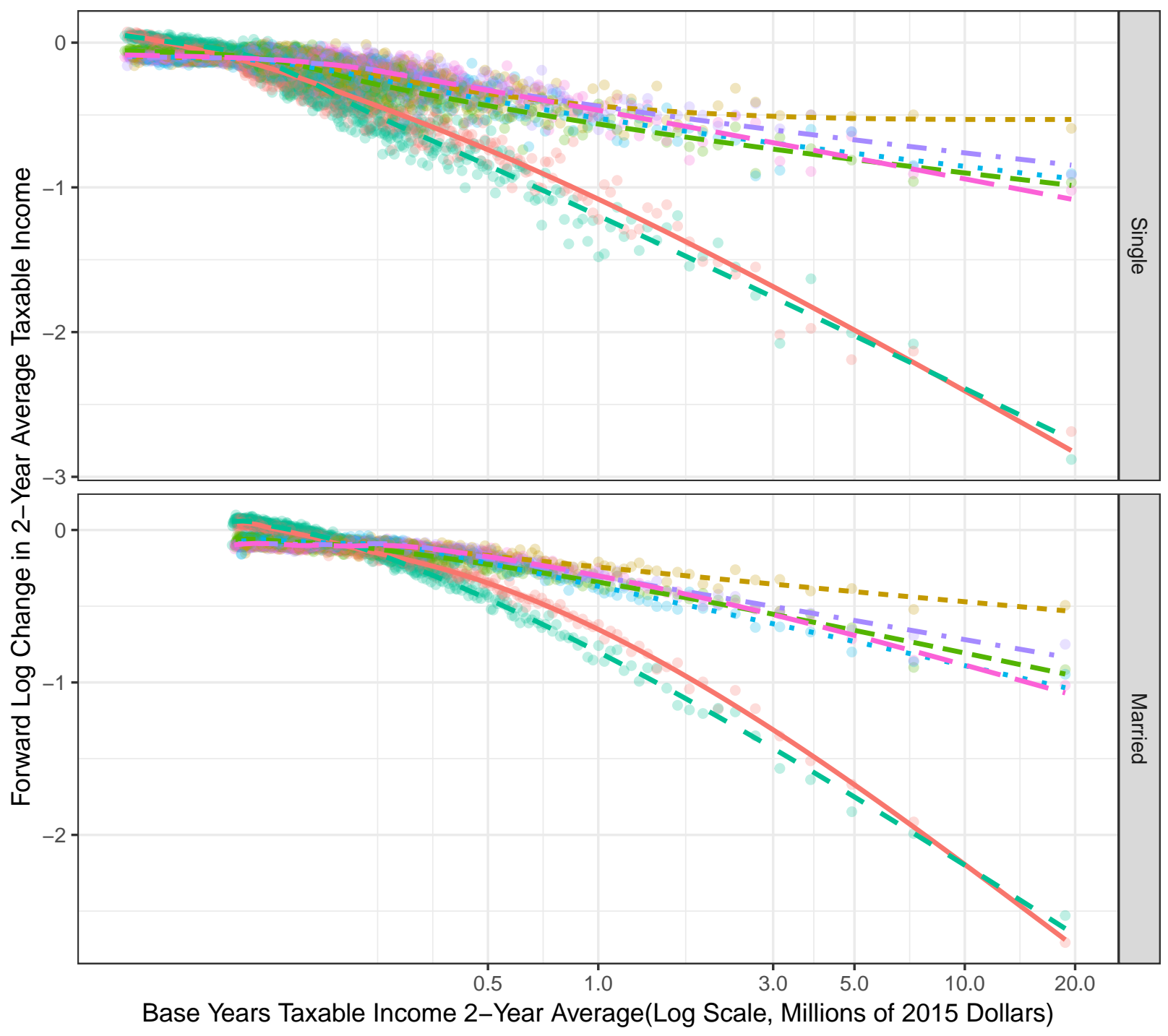

$$
\text { Year }=2000 / 1-2002 / 3-2004 / 5-2006 / 7-20012 / 13-2014 / 15
$$

Figure A3: Year on Year Log Change in Income, by Income and Year

This figure shows that the results from Figure A2 disappear once the results are averaged across 2-year periods. 


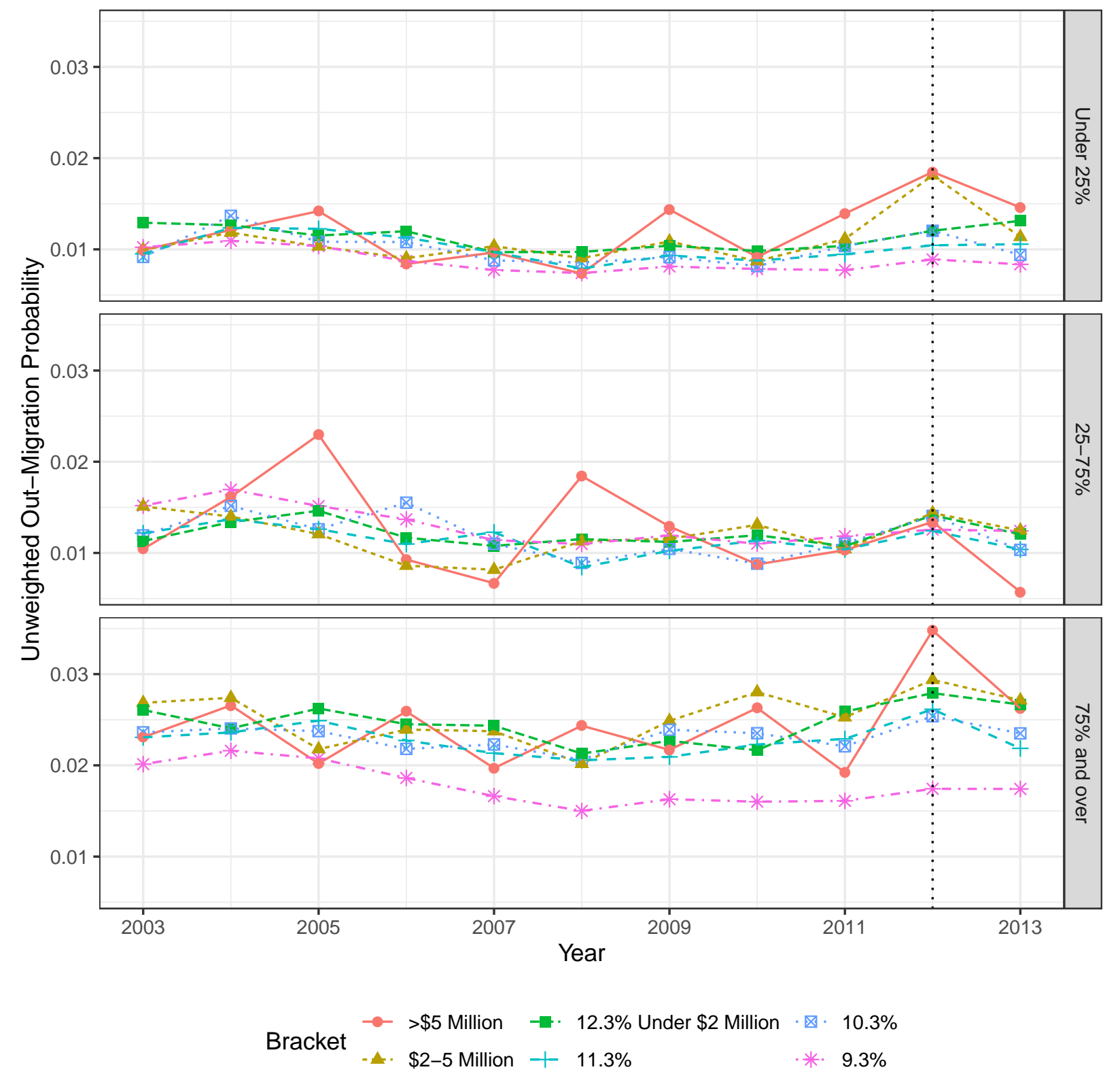

Figure A4: Out-Migration Probabilities, Wage Composition

This figure shows the out-migration probability of the specific income brackets by wage share from 2000-2013. 


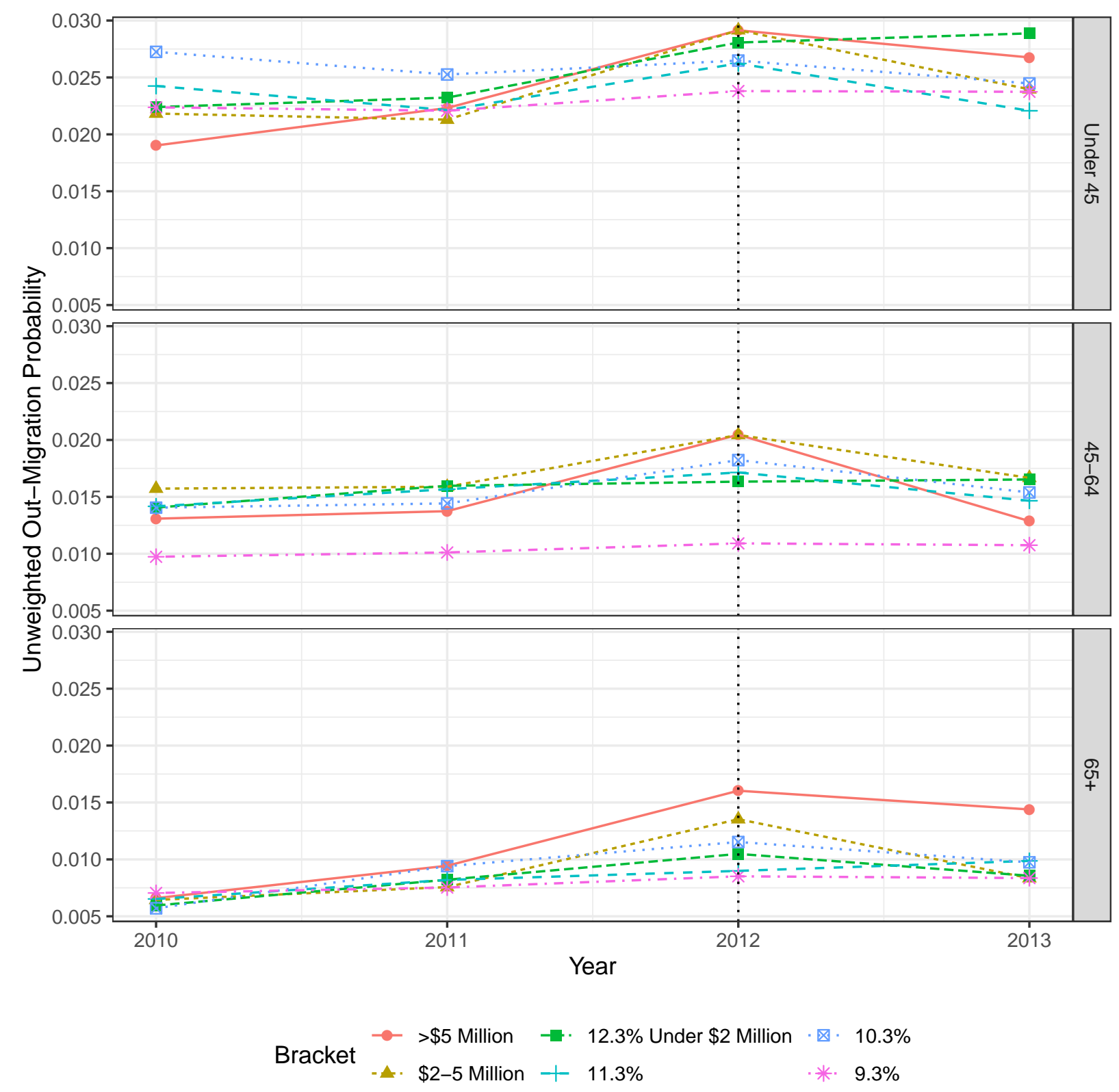

Figure A5: Out-Migration Probabilities, Age

This figure shows the out-migration probability by age group from 2010-2013. 


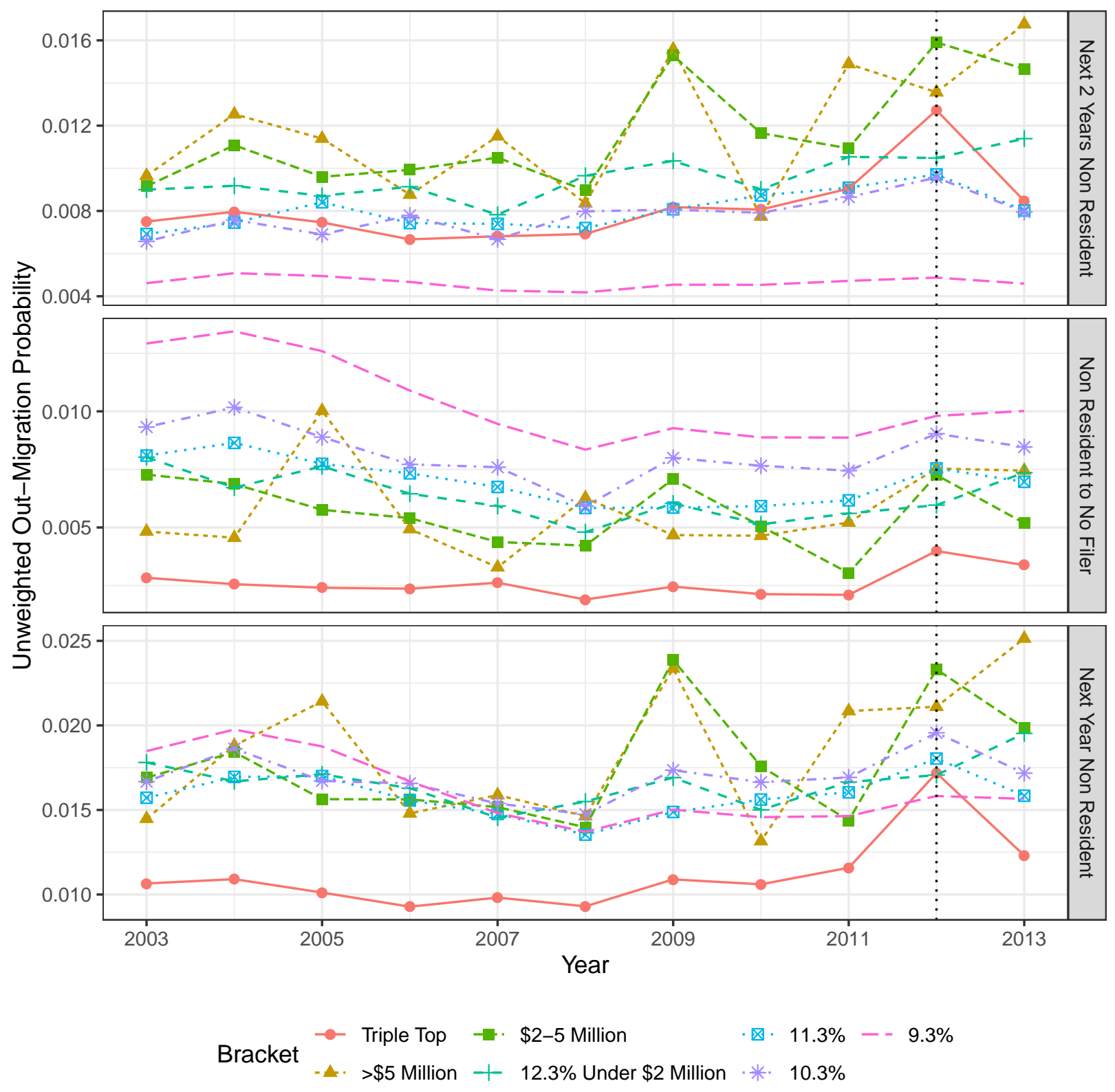

Figure A6: Out-Migration Probabilities, Top Bracket Persistence

This figure builds upon Figure 4 by showing the rate of out-migration among current-year residents who are in the income brackets below the top bracket in not only the current year, but also the past two years. 


\section{Destinations of Top-Bracket CA Out-Migrants (by Last Year of Residence)}
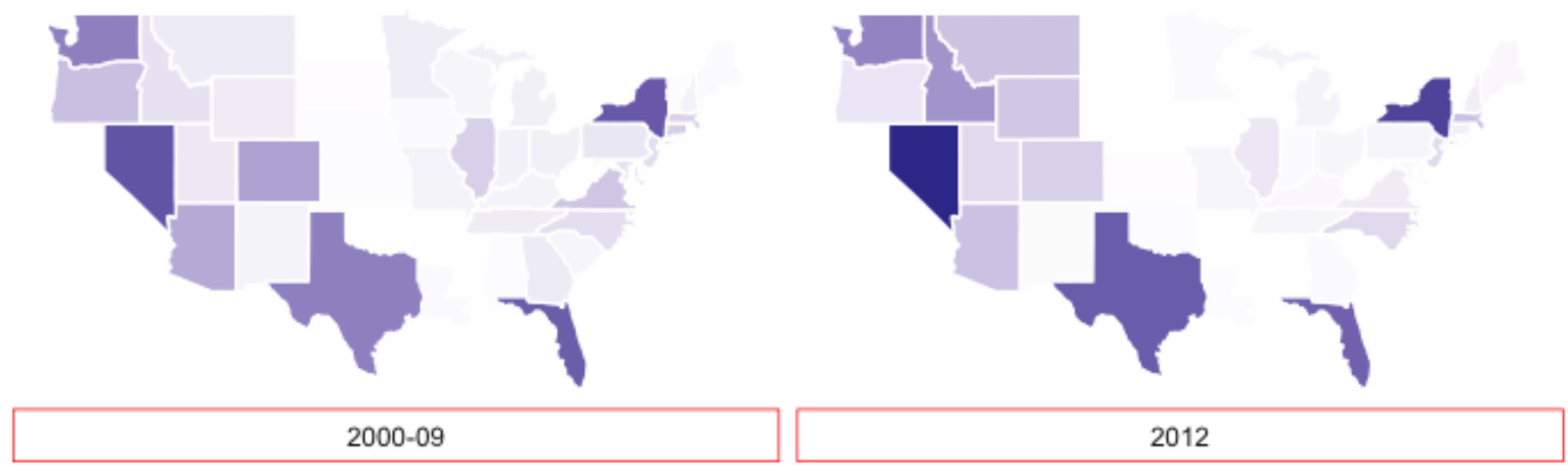

Percent of Exiting CA AGI

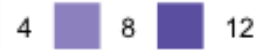

Figure A7: Mover Destinations

California AGI differs from Federal AGI in two ways: (a) it includes only California source income; and (b) California and Federal law differ slightly in their definitions of AGI. 
Table A4: Average Ratio California AGI / Federal AGI

\begin{tabular}{ccc}
\hline \hline Year & File as Non Resident in 2011 & File as Resident in 2011 \\
\hline 2009 & 0.075 & 0.996 \\
2010 & 0.067 & 1.01 \\
2011 & 0.065 & 1.02 \\
2012 & 0.048 & 0.998 \\
2013 & 0.056 & 0.999 \\
2014 & 0.058 & 0.982 \\
\hline
\end{tabular}

This table shows the average ratio California AGI to Federal AGI for non-residents and residents respectively, as of 2011. 
Table A5: Movement Regressions: Unweighted, Granular Income Bins, Marital Status Heterogeneity

\begin{tabular}{|c|c|c|c|c|}
\hline & \multicolumn{4}{|c|}{ Marital Status } \\
\hline & $\begin{array}{l}\text { All } \\
(1)\end{array}$ & $\begin{array}{c}\text { Single } \\
(2) \\
\end{array}$ & $\begin{array}{c}\text { Married } \\
(3) \\
\end{array}$ & $\begin{array}{c}\mathrm{HoH} \\
(4) \\
\end{array}$ \\
\hline $\begin{array}{l}\text { 12.3\% Brach } \\
1\{2011\}\end{array}$ & $\begin{array}{c}0.002^{* * *} \\
(0.001)\end{array}$ & $\begin{array}{l}0.004^{* *} \\
(0.001)\end{array}$ & $\begin{array}{c}0.001 \\
(0.001)\end{array}$ & $\begin{array}{c}0.006 \\
(0.003)\end{array}$ \\
\hline $\mathbf{1}\{2012\}$ & $\begin{array}{c}0.003^{* * *} \\
(0.001)\end{array}$ & $\begin{array}{c}0.004^{* * *} \\
(0.001)\end{array}$ & $\begin{array}{l}0.002^{* *} \\
(0.001)\end{array}$ & $\begin{array}{c}0.005 \\
(0.003)\end{array}$ \\
\hline $\mathbf{1}\{2013\}$ & $\begin{array}{c}0.003^{* * *} \\
(0.001)\end{array}$ & $\begin{array}{c}0.004^{* * *} \\
(0.001)\end{array}$ & $\begin{array}{l}0.002^{*} \\
(0.001)\end{array}$ & $\begin{array}{c}0.005 \\
(0.003)\end{array}$ \\
\hline \multicolumn{5}{|l|}{ 2-5 Million } \\
\hline $\mathbf{1}\{2011\}$ & $\begin{array}{c}0.002 \\
(0.001)\end{array}$ & $\begin{array}{c}0.006 \\
(0.003)\end{array}$ & $\begin{array}{c}0.001 \\
(0.001)\end{array}$ & $\begin{array}{l}-0.001 \\
(0.006)\end{array}$ \\
\hline $\mathbf{1}\{2012\}$ & $\begin{array}{c}0.006^{* * *} \\
(0.001)\end{array}$ & $\begin{array}{l}0.008^{*} \\
(0.003)\end{array}$ & $\begin{array}{c}0.006^{* * *} \\
(0.001)\end{array}$ & $\begin{array}{c}0.001 \\
(0.006)\end{array}$ \\
\hline $\mathbf{1}\{2013\}$ & $\begin{array}{c}0.002 \\
(0.001)\end{array}$ & $\begin{array}{c}0.004 \\
(0.003)\end{array}$ & $\begin{array}{c}0.002 \\
(0.001)\end{array}$ & $\begin{array}{c}0.004 \\
(0.007)\end{array}$ \\
\hline $\begin{array}{l}5 \text { Million + } \\
\mathbf{1}\{2011\}\end{array}$ & $\begin{array}{c}0.002 \\
(0.002)\end{array}$ & $\begin{array}{c}0.002 \\
(0.005)\end{array}$ & $\begin{array}{c}0.002 \\
(0.002)\end{array}$ & $\begin{array}{l}-0.005 \\
(0.007)\end{array}$ \\
\hline $\mathbf{1}\{2012\}$ & $\begin{array}{c}0.007^{* * *} \\
(0.002)\end{array}$ & $\begin{array}{l}0.012^{*} \\
(0.005)\end{array}$ & $\begin{array}{l}0.006^{* *} \\
(0.002)\end{array}$ & $\begin{array}{c}0.009 \\
(0.010)\end{array}$ \\
\hline $\mathbf{1}\{2013\}$ & $\begin{array}{c}0.002 \\
(0.002)\end{array}$ & $\begin{array}{l}-0.001 \\
(0.004)\end{array}$ & $\begin{array}{c}0.003 \\
(0.002)\end{array}$ & $\begin{array}{c}0.012 \\
(0.012)\end{array}$ \\
\hline Observations & $43,851,430$ & $19,146,163$ & $22,150,819$ & $2,554,448$ \\
\hline $\mathrm{R}^{2}$ & 0.001 & 0.0001 & 0.0003 & 0.0002 \\
\hline Adjusted $\mathrm{R}^{2}$ & 0.001 & 0.0001 & 0.0003 & 0.0001 \\
\hline
\end{tabular}


Table A6: Movement Regressions: Income Weightees, MSA Heterogeneity

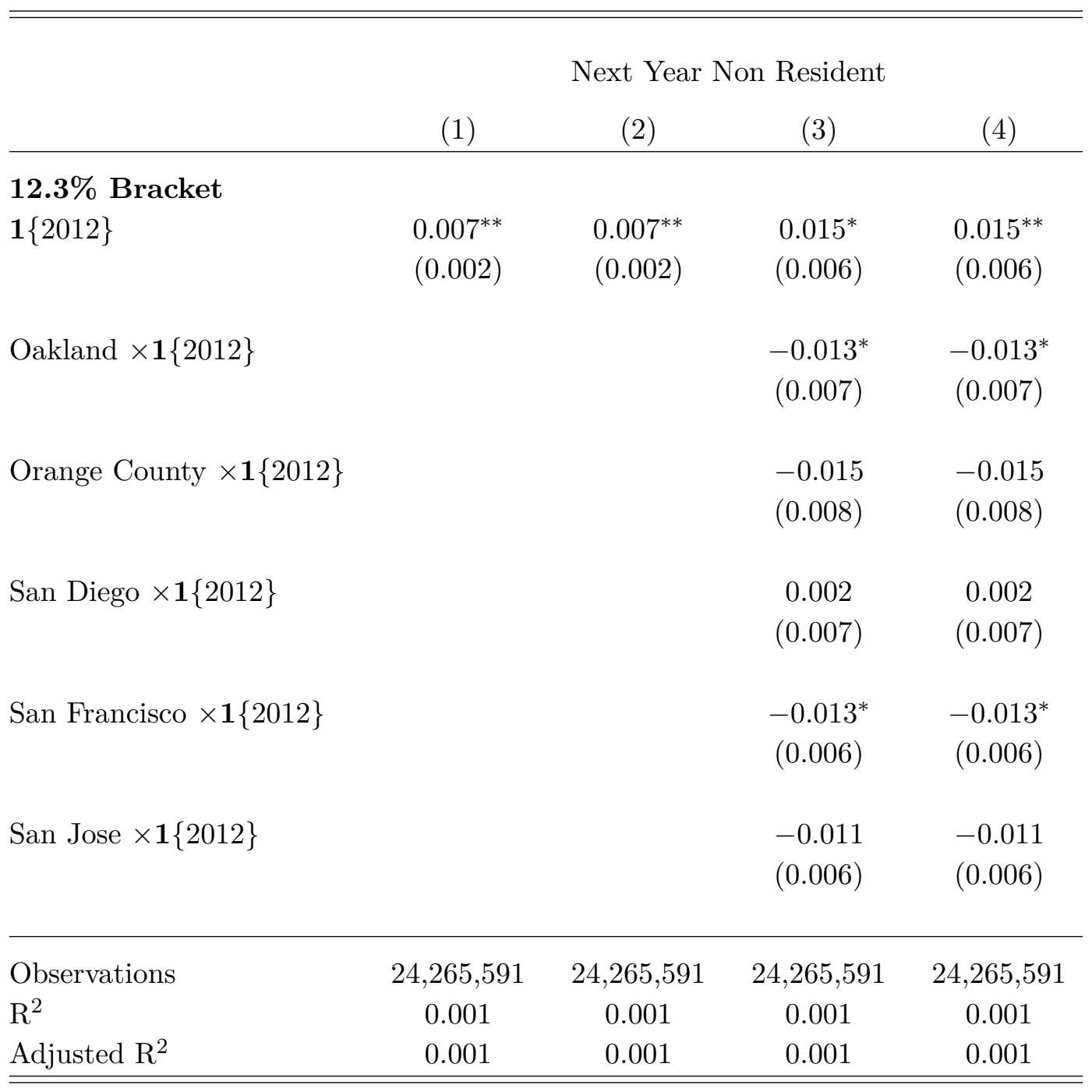

Regressions include years 2000-2013 but also exclude all taxpayers below the $9.3 \%$ bracket. All specifications contain marital status and year fixed effects. 2000-2010 is the "pre" period, and differences in differences effects are estimated for years 2011-13. Standard errors are clustered by taxpayer and location. Income controls include log income and fixed effects for 100 income percentiles. Regressions weighted by taxable income. Baseline is Los Angeles - Long Beach MSA.

Location based on year $t-1$ county. $t-1$ is used because as of filing for year $t$, many taxpayers are already out of California and filing from another state.

${ }^{*} \mathrm{p}<0.05 ;{ }^{* *} \mathrm{p}<0.01 ;{ }^{* * *} \mathrm{p}<0.001$ 
Table A7: Movement Regressions: Unweighted, Destination Heterogeneity

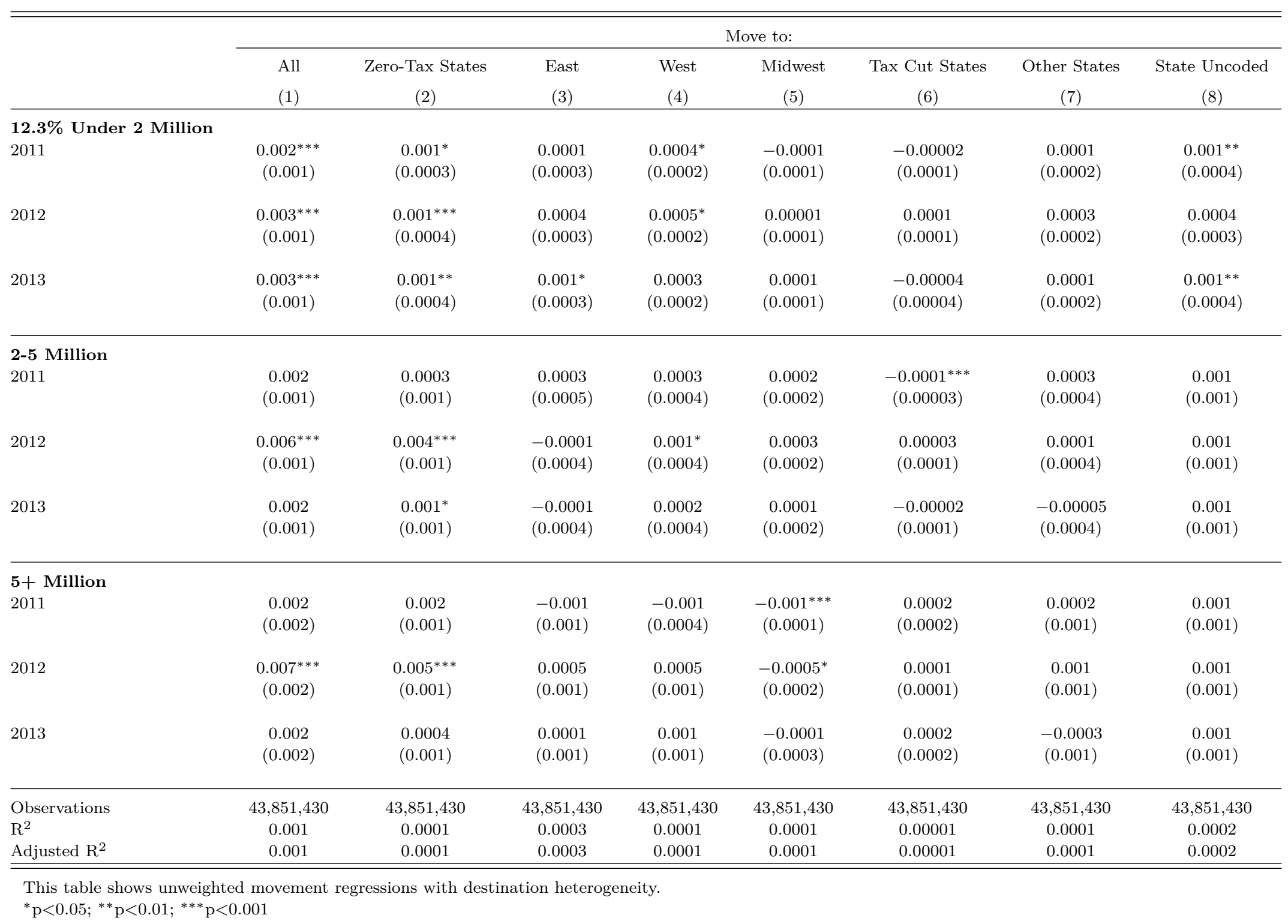


Table A8: Out-Migration Summary Statistics, 2000-09, Destination Heterogeneity

\begin{tabular}{cccccccc}
\hline \hline & \multicolumn{8}{c}{ Percentage Chance of Next-Year Non Resident Filing } \\
\cline { 2 - 8 } Income Bin & $\begin{array}{c}\text { Zero } \\
\text { Tax }\end{array}$ & East & West & Midwest & $\begin{array}{c}\text { Tax } \\
\text { Cut }\end{array}$ & $\begin{array}{c}\text { Other } \\
\text { States }\end{array}$ & $\begin{array}{c}\text { Destination } \\
\text { Uncoded }\end{array}$ \\
\hline > $\$ 5$ Million & 0.428 & 0.233 & 0.159 & 0.070 & 0.005 & 0.219 & 0.410 \\
$\$ 2-5$ Million & 0.394 & 0.246 & 0.181 & 0.056 & 0.013 & 0.215 & 0.415 \\
$12.3 \%$ Under $\$ 2$ Million & 0.376 & 0.253 & 0.177 & 0.069 & 0.012 & 0.237 & 0.466 \\
$11.3 \%$ & 0.346 & 0.270 & 0.186 & 0.074 & 0.013 & 0.244 & 0.464 \\
$10.3 \%$ & 0.359 & 0.264 & 0.211 & 0.082 & 0.014 & 0.256 & 0.526 \\
$9.3 \%$ & 0.366 & 0.196 & 0.253 & 0.095 & 0.017 & 0.318 & 0.437 \\
\hline
\end{tabular}

This table reports that the baseline rates of migration from California to various types of states. These figures supply the necessary ingredients for the numerator of the elasticity calculations. 
Figure A8: In-Migration

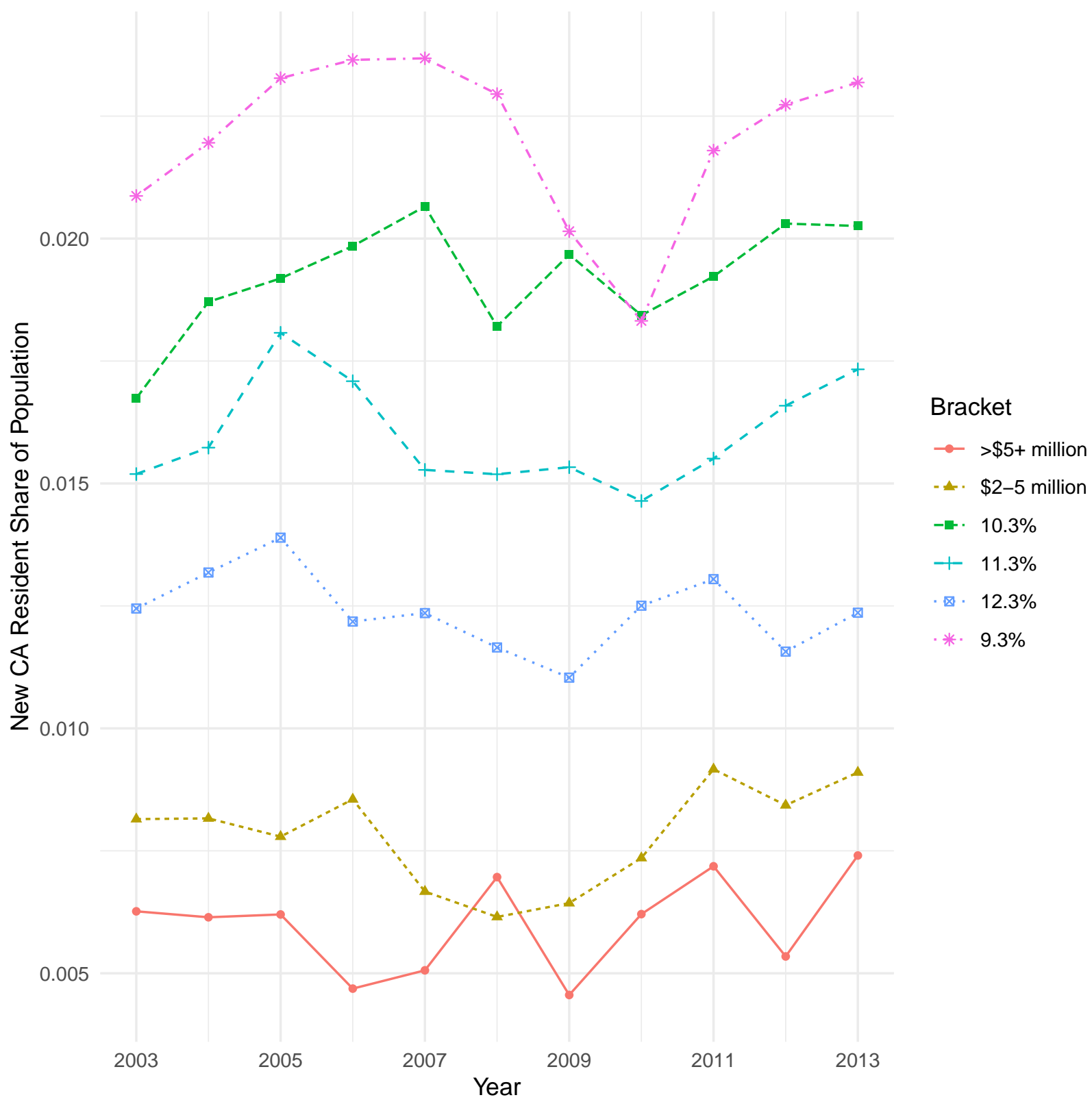

This figure shows the in-migration share of the specific income brackets. 
Figure A9: Raw Diff in Diff Trends
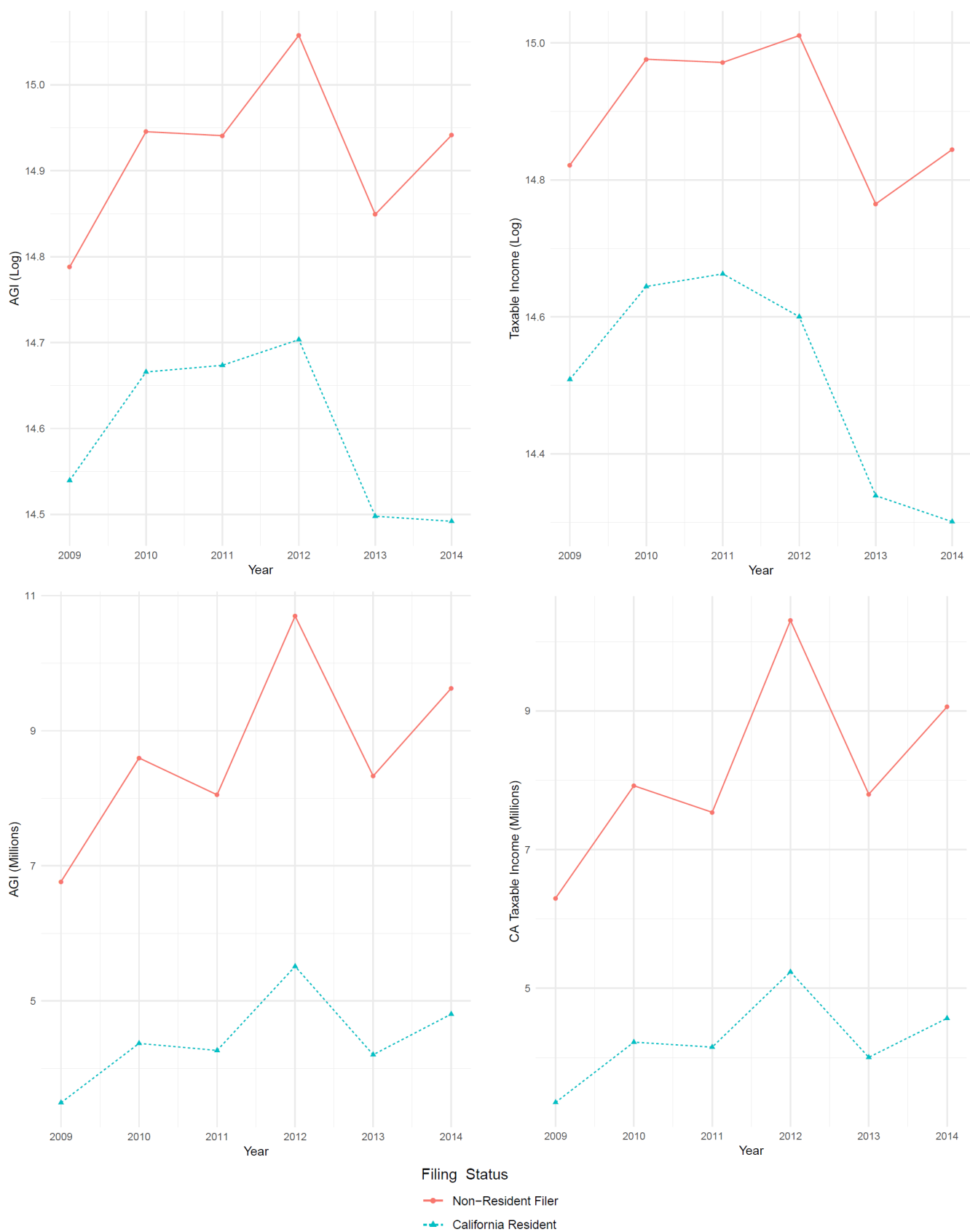

These figures show the raw plots of the differences-in-differences for levels and logs of taxable income. The "control group" is defined as those taxpayers who file non-resident returns in California in every year from 2009 to 2014 , and whose inflation-adjusted California taxable income would have placed them in the top California bracket (as introduced under Proposition 30) for 2009-11. As is evident in this figure, non-resident filers in the control group display substantially higher earnings than do residents. 
Table A9: Matched Differences in Differences: Single Households

\begin{tabular}{lcccc}
\hline \hline & \multicolumn{4}{c}{ Dependent Variable } \\
\cline { 2 - 5 } & Log(Taxable Income +1$)$ & Taxable Income & Log $($ AGI +1$)$ & AGI \\
& $(1)$ & $(2)$ & $(3)$ & $(4)$ \\
\hline Resident $\times 2012$ & $-0.132^{* * *}$ & $-0.495^{* * *}$ & $-0.093^{* * *}$ & $-0.324^{* * *}$ \\
& $(0.023)$ & $(0.090)$ & $(0.011)$ & $(0.089)$ \\
Resident $\times 2013$ & $-0.172^{* * *}$ & & & $-0.281^{* * *}$ \\
& $(0.033)$ & $-0.330^{* * *}$ & $-0.112^{* * *}$ & $(0.078)$ \\
Resident $\times 2014$ & $-0.280^{* * *}$ & $(0.071)$ & $(0.013)$ & $-0.530^{* * *}$ \\
& $(0.034)$ & $-0.572^{* * *}$ & $-0.189^{* * *}$ & $(0.092)$ \\
& & $(0.086)$ & $(0.015)$ & \\
\hline Observations & 178,782 & & & 178,782 \\
$\mathrm{R}^{2}$ & 0.447 & 178,782 & 0.707 \\
Adjusted $\mathrm{R}^{2}$ & 0.336 & 0.702 & 0.675 & 0.649 \\
\hline \hline
\end{tabular}

All regressions include taxpayer fixed effects. California residents are weighted to 1; California non-resident control group has weights applied with mean 1 and reflecting matched sample. with replacement. Levels variables are winsorized at $99.5 \%$. Standard errors are clustered by taxpayer. "Taxable Income" is under the California definition. That is, for California residents it is their California taxable income. For California non-residents, it is the taxable income of the taxpayer if they were a California resident and their full income were subject to California state taxation. ${ }^{*} \mathrm{p}<0.05 ;{ }^{* *} \mathrm{p}<0.01 ;{ }^{* * *} \mathrm{p}<0.001$ 
Table A10: Matched Differences in Differences: Married

\begin{tabular}{lcccc}
\hline \hline & \multicolumn{4}{c}{ Dependent Variable } \\
\cline { 2 - 5 } & Log(Taxable Income +1$)$ & Taxable Income & $\log ($ AGI +1$)$ & AGI \\
& $(1)$ & $(2)$ & $(3)$ & $(4)$ \\
\hline Resident $\times 2012$ & $-0.116^{* * *}$ & $-0.513^{* * *}$ & $-0.080^{* * *}$ & $-0.317^{* *}$ \\
& $(0.026)$ & $(0.120)$ & $(0.013)$ & $(0.119)$ \\
Resident $\times 2013$ & $-0.144^{* * *}$ & & & $-0.227^{*}$ \\
& $(0.039)$ & $-0.298^{* *}$ & $-0.088^{* * *}$ & $(0.102)$ \\
Resident $\times 2014$ & $-0.256^{* * *}$ & $(0.092)$ & $(0.014)$ & $-0.503^{* * *}$ \\
& $(0.038)$ & $-0.548^{* * *}$ & $-0.169^{* * *}$ & $(0.119)$ \\
& & $(0.111)$ & $(0.016)$ & \\
\hline Observations & 122,412 & & & 122,412 \\
$\mathrm{R}^{2}$ & 0.445 & 122,412 & 121,659 & 0.708 \\
Adjusted $\mathrm{R}^{2}$ & 0.325 & 0.706 & 0.705 & 0.645 \\
\hline \hline
\end{tabular}

All regressions include taxpayer fixed effects. California residents are weighted to 1; California non-resident control group has weights applied with mean 1 and reflecting matched sample. with replacement. Levels variables are winsorized at $99.5 \%$. Standard errors are clustered by taxpayer. "Taxable Income" is under the California definition. That is, for California residents it is their California taxable income. For California non-residents, it is the taxable income of the taxpayer if they were a California resident and their full income were subject to California state taxation. ${ }^{*} \mathrm{p}<0.05 ;{ }^{* *} \mathrm{p}<0.01 ;{ }^{* * *} \mathrm{p}<0.001$ 
Table A11: Matched Differences in Differences: Head of Household

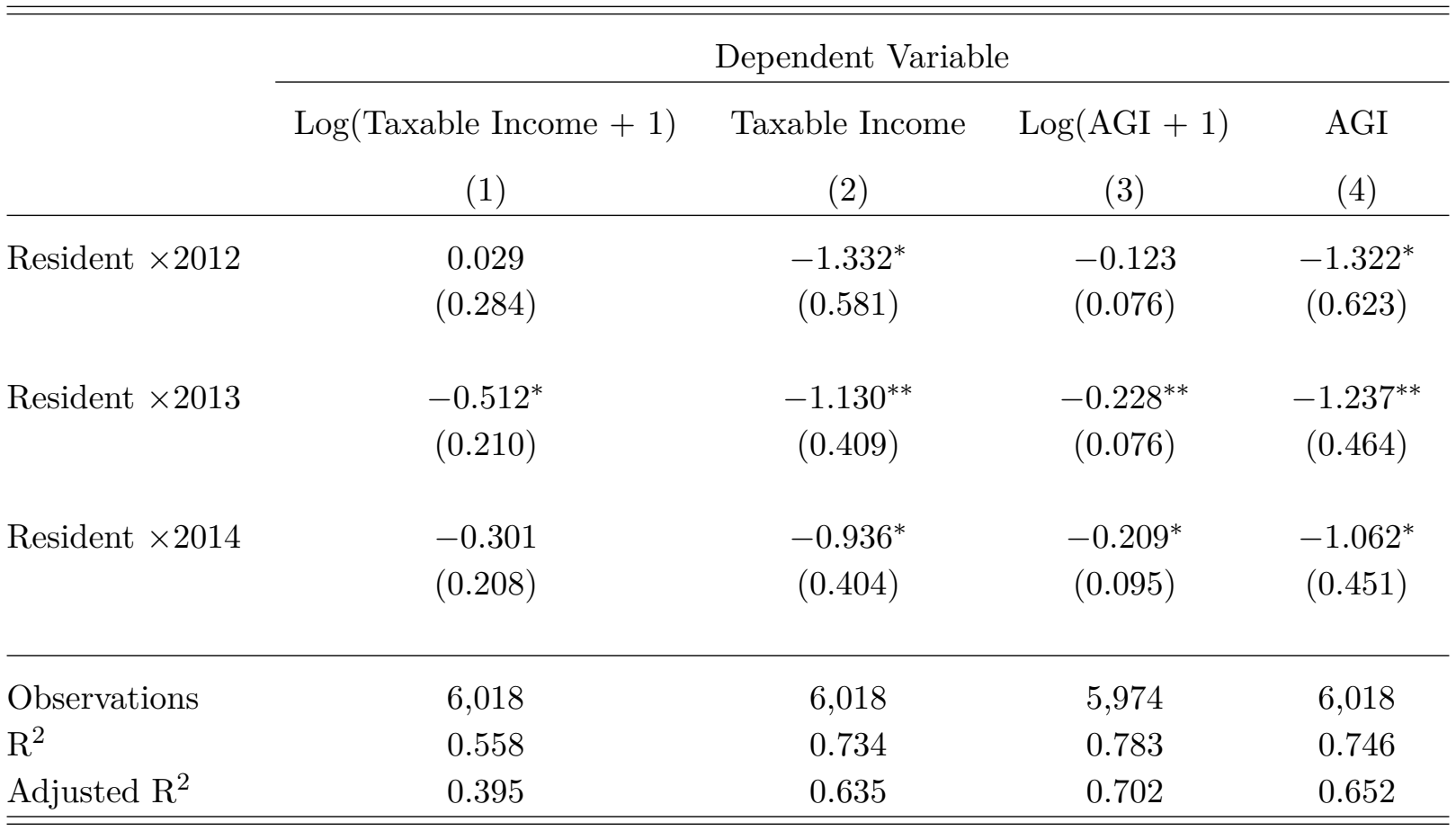

All regressions include taxpayer fixed effects. California residents are weighted to 1; California non-resident control group has weights applied with mean 1 and reflecting matched sample. with replacement. Levels variables are winsorized at $99.5 \%$. Standard errors are clustered by taxpayer. "Taxable Income" is under the California definition. That is, for California residents it is their California taxable income. For California non-residents, it is the taxable income of the taxpayer if they were a California resident and their full income were subject to California state taxation. ${ }^{*} \mathrm{p}<0.05 ;{ }^{* *} \mathrm{p}<0.01 ;{ }^{* * *} \mathrm{p}<0.001$ 
Table A12: Matched Differences in Differences - Dynamic Coefficients

Dependent Variable

$\overline{\log (\text { Taxable Income }+1) \quad \text { Taxable Income (Millions) } \quad \log (\text { Federal AGI + 1) } \quad \text { Federal AGI (Millions) }}$

(1)

(2)

(3)

(4)

\begin{tabular}{|c|c|c|c|c|}
\hline Resident $\times 2009$ & $\begin{array}{c}0.012 \\
(0.009)\end{array}$ & $\begin{array}{c}0.110 \\
(0.067)\end{array}$ & $\begin{array}{l}0.029^{* *} \\
(0.009)\end{array}$ & $\begin{array}{c}0.144 \\
(0.078)\end{array}$ \\
\hline Resident $\times 2010$ & $\begin{array}{l}-0.002 \\
(0.008)\end{array}$ & $\begin{array}{c}0.049 \\
(0.068)\end{array}$ & $\begin{array}{c}-0.002 \\
(0.008)\end{array}$ & $\begin{array}{l}-0.051 \\
(0.083)\end{array}$ \\
\hline Resident $\times 2012$ & $\begin{array}{c}-0.129^{* * *} \\
(0.021)\end{array}$ & $\begin{array}{c}-0.442^{* * *} \\
(0.086)\end{array}$ & $\begin{array}{c}-0.084^{* * *} \\
(0.010)\end{array}$ & $\begin{array}{c}-0.293^{* *} \\
(0.091)\end{array}$ \\
\hline Resident $\times 2013$ & $\begin{array}{c}-0.169^{* * *} \\
(0.030)\end{array}$ & $\begin{array}{c}-0.278^{* * *} \\
(0.071)\end{array}$ & $\begin{array}{c}-0.103^{* * *} \\
(0.012)\end{array}$ & $\begin{array}{c}-0.250^{* *} \\
(0.082)\end{array}$ \\
\hline Resident $\times 2014$ & $\begin{array}{c}-0.277^{* * *} \\
(0.031)\end{array}$ & $\begin{array}{c}-0.519^{* * *} \\
(0.081)\end{array}$ & $\begin{array}{c}-0.180^{* * *} \\
(0.014)\end{array}$ & $\begin{array}{c}-0.500^{* * *} \\
(0.093)\end{array}$ \\
\hline Observations & 178,782 & 178,782 & 177,416 & 178,782 \\
\hline $\mathrm{R}^{2}$ & 0.447 & 0.702 & 0.729 & 0.707 \\
\hline Adjusted $\mathrm{R}^{2}$ & 0.336 & 0.642 & 0.675 & 0.649 \\
\hline
\end{tabular}

In this table, we present the results of the dynamic event study specification shown in equation 3. In this specification, the omitted year is the year before the treatment, and the test for deviation from would show opposite signed and significant coefficients.

${ }^{*} \mathrm{p}<0.05 ;{ }^{* *} \mathrm{p}<0.01 ;{ }^{* * *} \mathrm{p}<0.001$ 
Table A13: Increase in Average Tax Rate Difference Between California and Other States, 2017-18

\begin{tabular}{l|l} 
Income Bin & Increase in Average Tax Difference, California vs. Zero-Tax States \\
\hline $10.3 \%$ Bracket & 0.0197 \\
$11.3 \%$ Bracket & 0.0261 \\
$12.3 \%$ Bracket under $\$ 2$ Million & 0.0362 \\
$\$ 2-5$ Million & 0.0440 \\
$\$ 5$ Million + & 0.0485
\end{tabular}

This table repeats the exercise of Table 2, but computes how the 2018 CA-other state gap in average taxes paid grew over and above the 2017 CA-other state gap. The gap is reported only for the case of zero-tax states, that is states with zero state income tax. This is the same group as in the prior exercise, with the exception of Wyoming which changed policy between 2017-18. This group is as follows: Alaska, Florida, Nevada, Texas, South Dakota, and Washington. Taxpayer behavior is still fixed at year 2012, with inflation-indexed levels. 


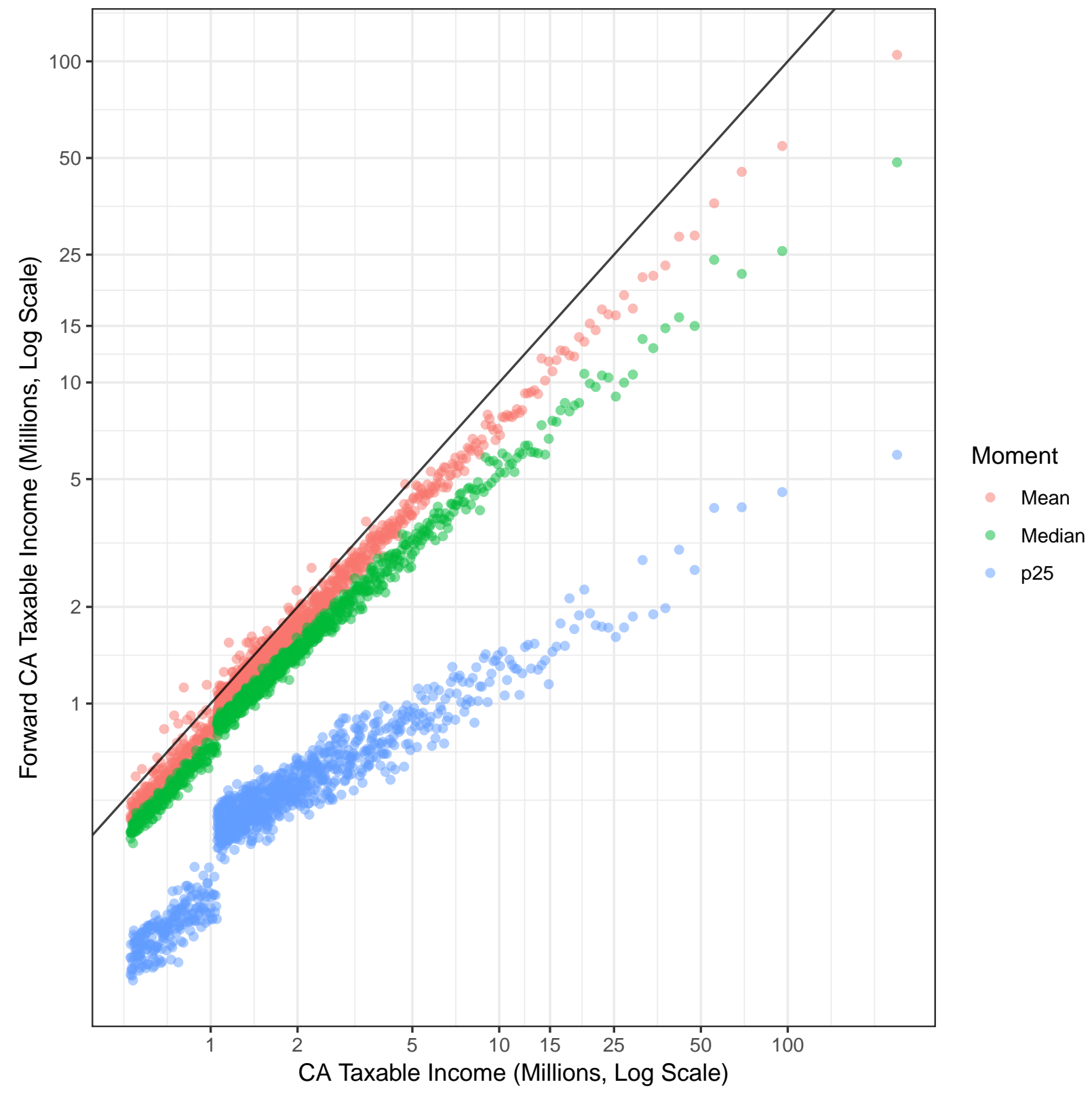

Figure A10: Year on Year Income Persistence

Sample is from 2000-2010. Solid line is the 45 degree line through the origin. 


\section{B. Components of Taxable Income}

This section summarizes IRS Form 1040 (Federal) and California FTB form 540 (California). Start with Federal AGI. Subtract "California subtractions" and add "California additions"; this gives California AGI ${ }^{42}$. Then, we have

$$
\text { Taxable Income }=(\text { California AGI - California Deductions })^{+}
$$

In the following we describe how Federal AGI is constructed, from an intermediate quantity known as Total Income. Note our data contain Taxable Income, California wages, Federal AGI, and California deductions for the universe of California tax returns.

\section{B.a. Components of Total Income}

\begin{tabular}{c|c} 
Variable & Data \\
\hline Federal Wages & Partial \\
Interest & Full \\
Dividends & Full \\
Taxable refunds, credits, or offsets of state and local income taxes & (Not Contained) \\
Alimony Received & Partial \\
Business Income & Partial \\
Capital Gains (Losses) & Full \\
Other Gains (Losses) & Partial \\
IRA Distributions & Partial \\
Rental Real Estate, Royalties, Partnerships, S-Corps, trusts, etc. & Partial \\
Farm Income (Loss) & Partial \\
Unemployment Compensation & Partial \\
Social Security Benefits & Partial \\
Other Income & Partial
\end{tabular}

\footnotetext{
${ }^{42}$ California AGI differs from Federal AGI in two ways: (a) it includes only California source income; and (b) California and Federal law differ slightly in their definitions of AGI.
} 


\section{B.b. Total Income to Federal AGI: Subtractions}

\begin{tabular}{c|c} 
Variable & Data \\
\hline Educator Expenses & Partial \\
Certain business expenses & Partial \\
Health savings account deduction & Partial \\
Moving expenses & Partial \\
Deductible part of self-employment tax & Partial \\
Self-employed SEP, SIMPLE, and qualified plans & Partial \\
Self-employed health insurance deduction & Partial \\
Penalty on early withdrawal of savings & Partial \\
Alimony paid & Not Included) \\
IRA deduction & Partial \\
Tuition and Fees & Partial \\
Student loan interest deduction & Partial \\
Domestic production activities deduction & Partial
\end{tabular}

